Portland State University

PDXScholar

10-29-1993

\title{
Common Security: a Conceptual Blueprint for an Israeli-Palestinian Political Settlement
}

Robert Arthur Horenstein

Portland State University

Follow this and additional works at: https://pdxscholar.library.pdx.edu/open_access_etds

Part of the Political Science Commons

Let us know how access to this document benefits you.

\section{Recommended Citation}

Horenstein, Robert Arthur, "Common Security: a Conceptual Blueprint for an Israeli-Palestinian Political Settlement" (1993). Dissertations and Theses. Paper 4591.

https://doi.org/10.15760/etd.6475

This Thesis is brought to you for free and open access. It has been accepted for inclusion in Dissertations and Theses by an authorized administrator of PDXScholar. Please contact us if we can make this document more accessible: pdxscholar@pdx.edu. 
AN ABSTRACT OF THE THESIS OF Robert Arthur Horenstein for the Master of Science in Political Science presented October 29, 1993.

Title: Common Security: A Conceptual Blueprint for an Israeli-Palestinian Political settlement

APPROVED BY THE MEMBERS OF THE THESIS COMMITTEE:

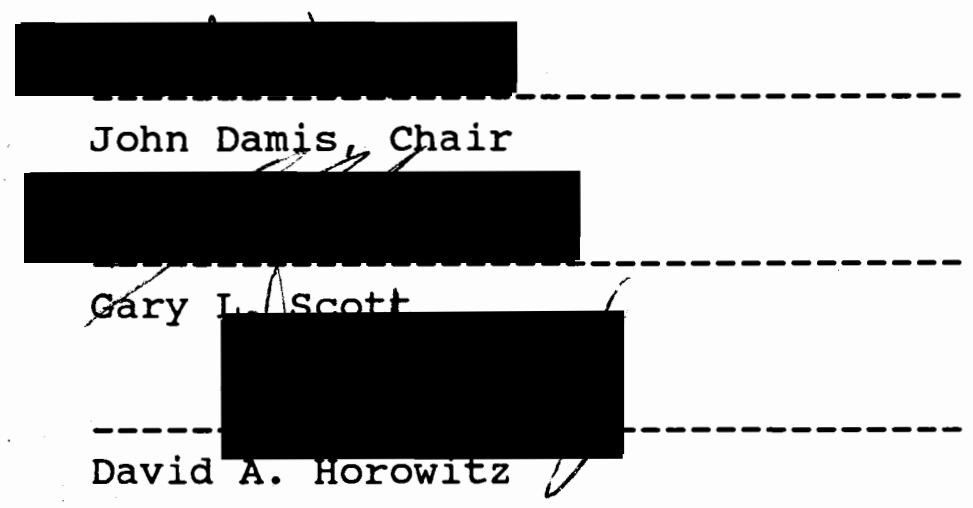

The deep-rooted Israeli-Palestinian conflict has been a major source of destabilization in the Middle East for some three-quarters of a century. Whereas other long-standing conflicts around the world have been brought to a close, this struggle (both in and of itself and within its wider Arab-Israeli dimension) remains a perennial tinderbox. This is particularly true given the unsettling realities of the region in which the conflict exists. Consequently, a certain sense of urgency for finding a permanent political settlement can be discerned both within the region and 
outside it. Still, the search for a solution has yielded progress only on an interim arrangement (the Gaza-Jericho autonomy accord signed by Israel and the PLO september 13, 1993).

To be workable, a political settlement must break new ground by conceptualizing the problem in terms which transcend the traditional, emotion-laden and myopic rhetoric commonly used by both sides. This research is an attempt to contribute to a fresh, far-reaching understanding of the requisites for a secure Israeli-Palestinian peace and, on this basis, to evaluate the alternative scenarios for the ultimate disposition of the Israeli-administered West Bank and Gaza Strip. To that end, the fundamental question is which of these alternatives would go furthest in satisfying the vital interests of both parties so that a permanent settlement of the disputed territories might at last be implemented.

In developing a conceptual framework for evaluating potential solutions, this research incorporates a comprehensive definition of "national security" juxtaposed with a concept related to American-Soviet détente: common security. National security means protection against all major perils to a state's security, not merely military threats. Common security is a mutual commitment to joint survival. It is based on a recognition that because of an increasingly 
interdependent world, states can no Ionger achieve security unilaterally but rather only through the creation of positive-sum processes that lead to cooperation with one another. The first half of this thesis, then, attempts to establish the essential elements of a common security framework for Israel and the Palestinian inhabitants of the West Bank and Gaza.

The concluding chapters of the thesis focus on the evaluation of five alternative scenarios for an IsraeliPalestinian political settlement: 1) the present status quo; 2) the "Jordanian option," or a return to the status quo ante of June 1967; 3) Israeli annexation; 4) an IsraelJordan confederation with a Palestinian entity federally linked to one or both; and 5) a Palestinian state, either fully independent or federally connected with Israel and/or Jordan. Each option is assessed on the basis of the degree to which it would satisfy the common-security criteria formulated in the preceding chapters: 1) protection against military threats; 2 ) the realization of Palestinian political self-determination; 3 ) the preservation of Israel's Jewish and democratic ideals; 4) internal (societal) and regional stability; 5) economic viability; and 6) the sufficient and equitable allocation of water resources. The alternative rated most favorably is the establishment of a sovereign, independent Palestinian state 
in the West Bank and Gaza, excluding the Jordan Valley and the Jerusalem Corridor. This assessment presupposes certain provisions. Among these are the deployment of an Americanled multinational peacekeeping force in the Samarian mountains of the West Bank, the creation of an economic confederation and tripartite federal water authority linking Israel, Jordan and Arab Palestine, and a special status for East Jerusalem. The implementation of such a settlement, it is argued, would create a new modus vivendi among the Arabs and the Israelis, which, in turn, could serve as the underpinning of a durable and comprehensive peace. 
COMMON SECURITY: A CONCEPTUAL BLUEPRINT

FOR AN ISRAELI-PALESTINIAN POLITICAL SETTLEMENT

By

ROBERT ARTHUR HORENSTEIN

A thesis submitted in partial fulfillment of the requirements for the degree of

\author{
MASTER OF SCIENCE \\ in \\ POLITICAL SCIENCE
}

Portland State University

1993 
TO THE OFFICE OF GRADUATE STUDIES:

The members of the Committee approve the thesis of Robert Arthur Horenstein presented October 29, 1993.

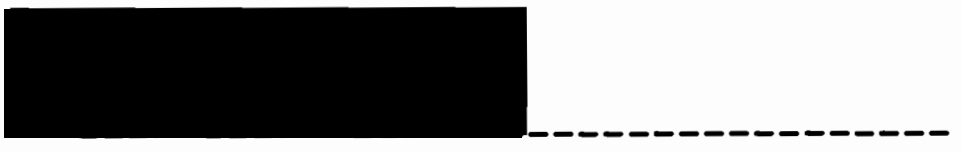

John Damis, Chair

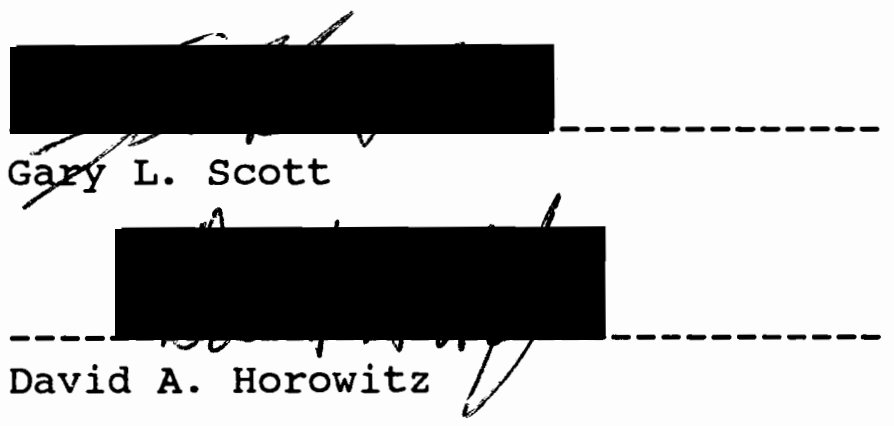

APPROVED:

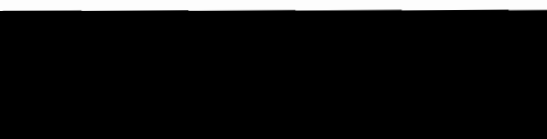

Gary L. Scott, Chair, Department of Political Science Roy W. Koch, Vice Provost for

Roy w. Koch, Vice Provost for Graduate studies and Research 


\section{ACKNOWLEDGEMENTS}

The writing of a meaningful thesis on the search for an Israeli-Palestinian peace is, to say the least, an immensely arduous and time-consuming project. I would like to thank Professors Gary L. Scott and John Damis, without whose abundant moral support and insightful advice this paper would not have been possible.

---R.A.H., October, 1993 
TABLE OF CONTENTS

PAGE

ACKNOWLEDGEMENTS . . . . . . . . . . . . . . . . iii

CHAPTER

I INTRODUCTION . . . . . . . . . . . . . . 1

Historical Background . . . . . . . 2

Overview of Research Goals .. . . . . 10

Chapter I Notes . . . . . . . . 16

II A ZERO-SUM CONFLICT? . . . . . . . . . . 17

Irreconcilable Territorial claims . . . 18

Historical Rights

Moral Imperatives

Obligations Under International Law

Chapter II Notes .. .. . . . . . 31

III COMMON SECURITY: ISRAELI-PALESTINIAN STYLE . . 33

Common Security Defined . . . . . . 36

Principles

What is National Security?

Military Security v. Self-Determination . . 42

Support for a settlement and Internal

Stability ........... . 47

The Demographic Threat . . . . . . 51 
III (Cont.)

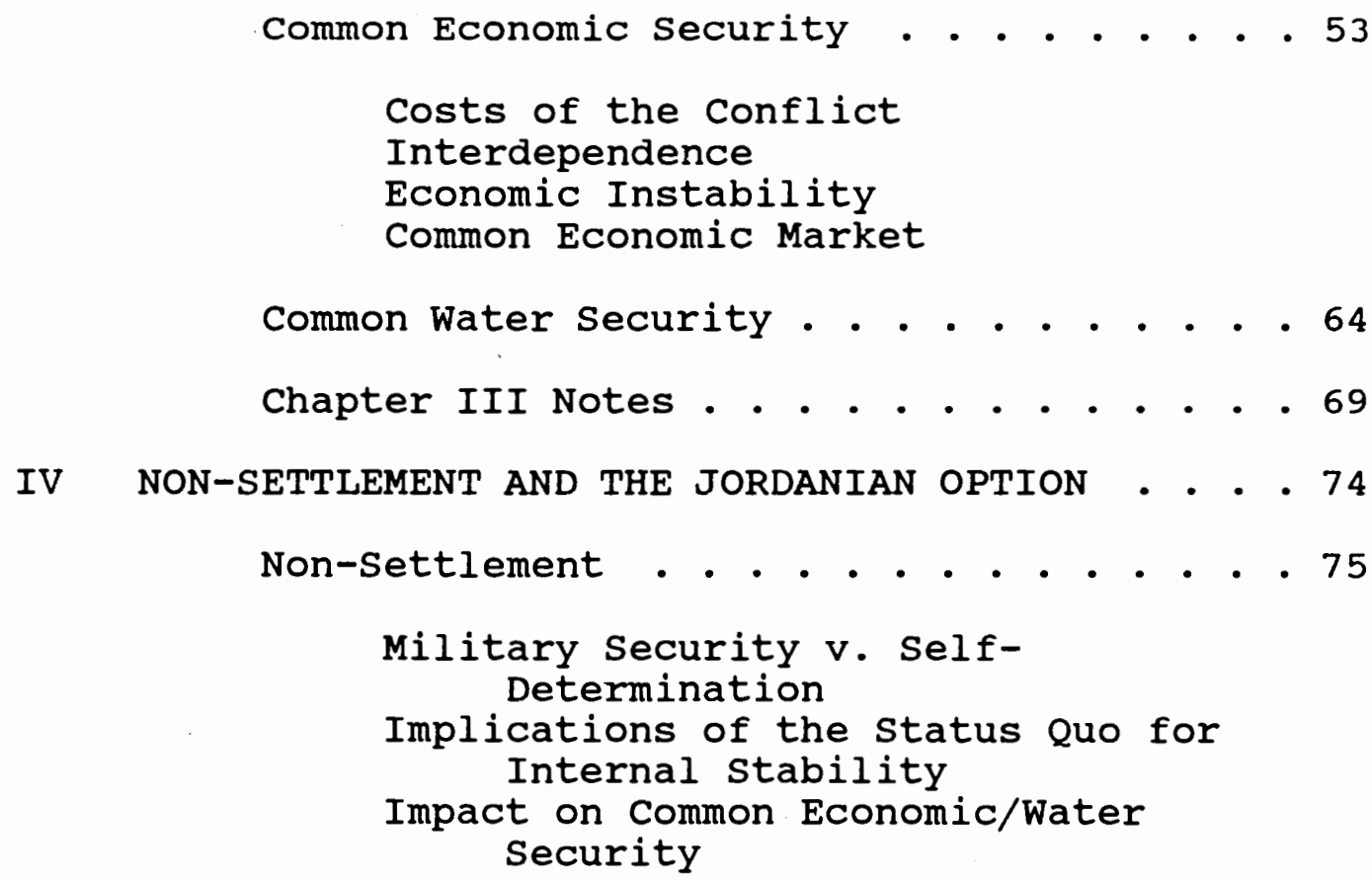

A Return to 1967?... . . . . . . . . 81

Secure Borders

Self-Determination Through Jordanian Citizenship?

Implications for Internal stability

Impact on Common Economic/Water security

Chapter IV Notes . . . . . . . . 94

V UNILATERAL ISRAELI ANNEXATION • • • • • • • • 97

Political Equality Within a Greater Israel? 98

Population Transfer . . . . . . . 102

Autonomy . . . . . . . . . . . . . 109

Territorial Autonomy

Autonomy v. Self-Determination

Chapter V Notes . . . . . . . . . 117 
VI THE FEDERAL APPROACH: SELF-RULE AND SHARED RULE 120 Impact on Military security . . . . . 123 Meaningful Self-Determination? . . . 125

Implications for Israel's Jewish and Democratic Nature . . . . . . 127

Economic Integration and Sharing of Water Resources . . . . . . 128

Palestinian Dissatisfaction and Internal Stability . . . . . . . 130 Chapter VI Notes . . . . . . . . 134 VII ARAB PALESTINE . . . . . . . . . . . 136 The Ultimate Form of Self-Determination . . 137 Implications for Israeli Military Security 138 Sovereignty v. Security Arrangements . . 143 Internal stability: Support for the Settlement ......... 150 Elimination of the Demographic Time Bomb. . 152 Common Economic Security or Severance of Economic Ties? . . . . . . 153

A Federal Arrangement for Water Allocation 155 Chapter VII Notes . . . . . . . 158 VIII CONCLUSION . . . . . . . . . . . 161 The Question of Jerusalem . . . . . 162 Partial Demilitarization . . . . . 164 Timeframe for Implementation . . . . 165 A Final Word .......... 166 Chapter VIII Notes . . . . . . . 169 
REFERENCES CITED . . . . . . . . . . . . . . 170 APPENDICES

A MIDDLE EAST BALANCE OF POWER . . . . . . . 175

B PROPOSED BOUNDARIES BETWEEN ISRAEL AND A

PALESTINIAN STATE . . . . . . . . 176 


\section{CHAPTER I}

\section{INTRODUCTION}

The deep-rooted Israeli-Palestinian conflict has been a major source of destabilization in the Middle East for some three-quarters of a century. Essential to any feasible solution of this conflict is the need to break new ground by conceptualizing the problem in terms which transcend the traditional, emotion-laden and myopic rhetoric commonly used by both sides.

This is not to say that to be workable, the ultimate solution of this problem must simply be bold enough to disregard completely the contradictory historical perspectives of the parties or ignore their profound ideological sensitivities. However, one of the major premises of this paper is that it is essential for Israelis and Palestinians to move beyond their contentious claims and counterclaims which are basically of a historical, moral or quasi-legal nature. As will be seen, these are nothing more than a recipe for perpetual gridlock. More importantly, it is only by adhering to a principle of common security, broadly defined, that these two peoples will ultimately find 
a resolution to their struggle for possession of and sovereignty over the same land.

The past several years have witnessed the occurrence of several groundbreaking events in the Arab-Israeli arena. Among these milestones have been the onset of the Palestinian Intifada (uprising); the November 1988 endorsement of a two-state solution by the Palestine Liberation organization (PLO); the historic convening of direct, bilateral ArabIsraeli negotiations in the aftermath of the 1991 Persian Gulf War; the victory of a left-of-center Labor Party in the 1992 Israeli elections; and, most recently, a mutual recognition accord and autonomy agreement between Israel and the PLO after months of secret talks in Norway. Nevertheless, in some respects, a final resolution of the Israeli-Palestinian conflict is only a modicum closer to reality than when the Palestinians began their uprising in late 1987.

\section{HISTORICAL BACKGROUND}

Because it is important to understand how the Israelis and Palestinians arrived at their present state of mutual animosity and frequent impasse, this study would be remiss if it did not provide a brief historical overview of their struggle within the context of the wider Arab-Israeli conflict. Reflective of the seeming intractability of the 
problem is the fact that the historical roots of the conflict can be traced back long before Israel's acquisition of the West Bank and Gaza Strip in 1967. It was during the latter half of the nineteenth century when Arab nationalism, which started as a reaction against ottoman hegemony, and Zionism, the movement to establish a Jewish national home in Palestine so that Jews could once and for all be insulated from anti-Semitism and assimilation, began to emerge in earnest. Thus, for over one-hundred years, the two national movements have been on a collision course with regard to the land which the Arabs refer to as Palestine and which the Jews call Eretz Israel (present-day Israel proper plus the West Bank and Gaza).'

After the defeat of the ottomans (Turkey) in World War I, the victorious Allied Powers in the form of the new League of Nations carved up the Arab provinces of the former ottoman Empire into mandates assigned to Great Britain and France. Britain acquired the mandate for Palestine and retained administrative responsibility for that territory until 1948. Even before the end of the war, the British government, in accordance with the Balfour Declaration of 1917, pledged its support for the establishment a Jewish national home in Palestine. Simultaneously, it promised the Arab nationalists it would assist them in the creation of an independent Arab state in Greater Syria, initially including 
Palestine. That such commitments were contradictory and seemingly impossible to reconcile did not bother the British as long as their immediate strategic interests were being served.

Between the world wars and thereafter, however, the British began to grasp the extent of Arab nationalist opposition to the increasing $\mathrm{Zionist}$ presence in Palestine, culminating in the Arab riots of 1936-39. They believed it politically expedient to try to appease the Arabs by limiting Jewish immigration into the area. The zionists, meanwhile, continued to insist even more adamantly that the British permit large-scale Jewish immigration and settlement in accordance with their earlier pledges, whose urgency was now greatly underscored by the revelations of Nazi atrocities against the Jews in Europe. The escalating conflict among the Arab nationalists, British and zionists notwithstanding, the latter managed to expand considerably their presence in Palestine; by 1940, Jews numbered 467,000, or thirty percent of the total population. ${ }^{2}$

After World War II, amid the horrifying disclosure that nearly ninety percent of European Jewry had been exterminated, international pressure mounted on Britain to open up immediately the gates of Palestine to an additional 100,000 Jewish refugees. The British, fearful of what would undoubtedly be a hostile reaction in the Arab world to the 
admission of so many Jewish émigrés, refused. By early 1947, however, they had become weary of the ongoing conflict in Palestine. In February, the British government, already badly overextended throughout its far-flung empire, announced that it was turning over the problem of Palestine to the newly created United Nations.

On November 29, 1947, the U.N. General Assembly voted 33 to 13, with ten abstentions, to accept the plan endorsed by a majority of the U.N. Special Committee on Palestine (UNSCOP): the partition of Palestine west of the Jordan River into two sovereign states, one Arab, the other Jewish. In addition, Terusalem and its surroundings were to be internationalized under permanent U.N. trusteeship. Thus, the right of the Jews to an independent state in part of Palestine--as well as the irreconcilability of the claims by these two peoples to the same geographic domain--was once and for all confirmed by the international community.

The Zionists, eager for international recognition of their right to statehood, accepted the partition proposal. The Palestinian Arabs, however, backed unanimously by the Arab states, rejected partition because they had for so long constituted an overwhelming--albeit declining--majority of the population in Palestine. As a result, civil war immediately erupted between the Jewish and Arab inhabitants. In May 1948, as the mandate expired and the last British 
troops were withdrawn, the zionists proclaimed the birth of the modern state of Israel, which was immediately invaded by the expeditionary forces of five Arab states. Thus, what had been violent intercommunal discord rapidly escalated into the first full-fledged Arab-Israeli war.

As a result of Israel's war of independence, the zionists not only secured their fledgling state but, in addition, captured sections in the Galilee, Jerusalem and Negev regions which had originally been allocated to Arab Palestine by the U.N. partition plan. The West Bank and Gaza Strip, or the remainder of what was to be the Arab state, were occupied by Jordan and Egypt, respectively. For the Palestinian Arabs, both the civil war and the wider Arab-Israeli war were devastating: of the approximately 860,000 Arabs who had lived in that part of Palestine which was now the state of Israel (based on the 1949 armistice lines), 727,000 fled, or, in some cases, were expelled. of these, 470,000 entered refugee camps in the West Bank and Gaza while most of the remainder were scattered among Lebanon, Syria and Jordan proper. ${ }^{3}$

During the next forty years, there were five more ArabIsraeli wars, in 1956, 1967, 1969-70, 1973 and 1982. In the monumental 1967 Six-Day War, Israel preempted an imminent Arab invasion and defeated Egypt, Jordan and Syria, thereby acquiring the West Bank, including East Jerusalem, and Gaza 
(as well as the Golan Heights from Syria). Israel has been in control of these territories ever since--in fact, it has unilaterally annexed East Jerusalem and the Golan--and is governing the 1.9 million Palestinian Arabs therein. Whether refugees from the 1947-48 war or indigenous inhabitants, these Palestinians consider the West Bank and Gaza, at a minimum, to be their national homeland. Still, the intifada, that Palestinian ground swell to "shake off" what is considered to be an illegal Israeli occupation of Arab lands, erupted only after twenty years of Israeli rule. There can be no question that the Palestinian residents of the West Bank and Gaza have always felt that Israeli control of what they consider to be their national territory is contrary to their vital interests and collective rights. But not until the last decade did critical events unfold which placed the Israeli-Palestinian conflict at a crossroads.

By the early $1980^{\prime} \mathrm{s}$, a dramatic rise in the number of Jewish settlements in the administered territories along with a large-scale expansion of existing ones began to take place. This increase occurred against a backdrop of a political trend in Israel which seemed to reflect a growing shift toward both the secular and religious right (i.e., toward a sentiment favoring the incorporation of the West Bank and Gaza into a Greater Israel). Compounding the 
resultant sense of frustration among the Palestinians were the defeat of the PLo in Lebanon in 1982-1983 and the Arab states' subsequent inattentiveness toward and inability (if not reluctance) to do anything about the Israeli occupation. Perhaps the largest disappointment for the Palestinians was the November 1987 Arab League summit in Amman. At this gathering of Arab leaders, the Iran-Iraq war was given primacy while the Israeli-Palestinian conflict was placed on the diplomatic back burner.

Clearly, it has been Israel's rapid settlement drive in the territories along with a concomitant effort to link the settlements institutionally and economically to Israel proper which has ultimately reinforced the perception among the Palestinian population that a solution to their predicament is not close at hand. In 1977 , ten years after the Israeli conquest of the West Bank and Gaza, the Jewish population there was still quite small, less than 4,500. By contrast, in 1988, after more than a decade of right-wing Likud rule, 130 settlements with 65,000 residents were dispersed throughout the territories, making it increasingly doubtful that this "creeping annexation" could ever be reversed. 4

As of this writing, the Jewish population in the territories, boosted in large part by a housing blitz $(20,000$ building starts) launched in the last two years of 
the preceding Iikud administration, has increased to well over 120,000 in some 140 settlements. There are an additional 150,000 Jews residing in East Jerusalem and its five satellite towns. Mark Heller and Sari Nusseibeh estimate, moreover, that 41 percent of the West Bank alone has been directly seized by the Israeli government as "public [state] land." 5

In the first eight months of 1993, secret Israeli-PLO negotiations held in Norway produced the outline of an interim settlement on autonomy for the Arab inhabitants of the Gaza strip and the West Bank town of Jericho. This agreement, signed on september 13 in Washington following an exchange of statements by the parties formally recognizing each other's legitimacy, is a major conceptual breakthrough with potentially far-reaching ramifications. Nevertheless, some Palestinians continue their resistance in the west Bank and Gaza, albeit on a much more sporadic, less intense level than that which the intifada possessed in its formative years. Without continued progress in the diplomatic arena, another violent eruption in the territories cannot be ruled out; indeed, it may be imminent. 
OVERVIEW OF RESEARCH GOALS

The purpose of this research is to attempt to contribute to a fresh, far-reaching understanding of the requisites for a secure Israeli-Palestinian peace and, on this basis, to evaluate the alternative scenarios for the ultimate disposition of the Israeli-controlled West Bank and Gaza Strip. To that end, the basic question is which of these alternatives would go furthest in satisfying the vital interests of both the Israelis and the Palestinians so that a permanent settlement of the disputed territories might at last be implemented.

Chapter Two begins with an examination of what this study refers to as the zero-sum approaches to the IsraeliPalestinian conflict. These not only have pervaded the rhetoric used by both sides but have also made their way into the vast array of literature on the subject. Specifically, this chapter stresses the need to move beyond such approaches, whose overt subjectivity and polemic nature hardly render them conducive to compromise formulas. Taking it one step further in the search for a political solution, the Israelis and Palestinians must eventually come to understand that their fundamental interests, like their destinies, are unalterably bound together. It will therefore get them nowhere to seek illusory gains vis-à-vis the other which are mutually exclusive. Included in the latter 
category are one-sided security advantages that ensure the national survival of one at the expense of the other.

Michael Klare and Daniel Thomas argue that the concept of security must include protection against all significant threats to the national well-being, not merely military threats, which in the past were seen as the only real danger to national survival. They note, moreover, that the quest for such an all-encompassing security "is rapidly becoming a positive-sum process, whereby national well-being is achieved jointly by all...or not at all [emphasis added]."6 In other words, whereas security goals (e.g., defense against enemy attack) might once have been pursued through zero-sum, unilateral actions (e.g., the conquest and annexation of enemy territory), now the achievement of such goals necessitates a positive-sum approach ${ }^{7}$

This is precisely why many observers believe that the current Arab-Israeli multilateral discussions taking place in various world capitals may provide the impetus for substantive breakthroughs in the more prominent washingtonbased, direct bilateral talks between Israel and its Arab neighbors. For it is problems such as arms control, hindered economic development, scarcity of water resources and the environment--all security concerns by Klare and Thomas's definition--which require the parties to adopt a 
positive-sum outlook. It is these sorts of intricate, region-wide issues which compel long-time enemies to grasp the necessity for cooperation and compromise if they are ever to be truly resolved.

The notion of "common security" may be particularly instructive here. The concept is generally associated with East-West relations during the cold War, but it is equally applicable to the Middle East with its ubiquitous stockpiles of ballistic missiles and chemical and biological weapons. As Thomas Risse-Kappen notes, "Common security means that, in the nuclear age, neither side can feel secure if one side feels threatened." 8

Risse-Kappen argues that a cessation of the cold War did not even become a realistic possibility until the mid1980's when the U.S.-Soviet détente process finally instituted common security as the underlying philosophy governing the East-West conflict. Specifically, it was only after the ascendancy of Mikhail Gorbachev, who embraced this concept, that the U.S.-Soviet arms control negotiations developed into a positive-sum process. This transformation ultimately enabled the two sides to make significant, mutually verifiable nuclear and conventional arms cuts. 9 Thus, adherence to the notion of common security was, arguably, à necessary--albeit perhaps insufficient-condition for an end to the cold war. 
Chapter Three borrows from the Klare-Thomas framework juxtaposed with this cold war notion of common security. It applies these two complementary perspectives to the specific situation confronting Israel and the Palestinians in the West Bank and Gaza as well as to the wider Arab-Israeli conflict inasmuch as it is directly relevant to the latter. That is, this study not only considers the relevance of common security to the highly militarized and volatile Middle East; it extrapolates further by examining the concept's applicability to the multitude of threats, not all military, which the Israelis and Palestinians pose to each other's well-being (and in Israel's case, perhaps to its very survival as a democratic and Jewish state). The fundamental question addressed in this chapter is: if common security is to be invoked as the conceptual framework underlying Israeli-Palestinian coexistence, which elements must be included?

The concluding chapters of this research analyze alternative scenarios concerning the ultimate disposition of the West Bank and Gaza Strip. Each scenario is evaluated on the basis of the comprehensive common security framework developed in Chapter Three. The five most widely discussed alternatives are examined: 1) the present status quo, or what some authors refer to as non-settlement of the conflict; 2) the "Jordanian option," or a return to the 
status quo ante of June $1967 ; 3$ ) three versions of Israeli annexation of the territories, each different in terms of its implications for the Palestinian inhabitants--Israeli citizenship, population transfer and autonomy; 4) an IsraelJordan confederation with a Palestinian entity federally linked to one or both; and 5) a Palestinian state, either fully independent or federally connected with Israel and/or Jordan.

Whereas some long-standing conflicts around the world have been brought to a close, the Israeli-Palestinian conflict (both in and of itself and within its wider ArabIsraeli dimension) remains a perennial tinderbox. This is particularly true because of the unsettling realities of the region in which the conflict exists: a nuclear-armed Israel encircled by autocratic Arab states, themselves possessing ballistic missiles and unconventional weapons; a violent, albeit sporadic, uprising in the West Bank and Gaza; a troublesome number of overcrowded slums in large Arab urban centers and squalid Palestinian refugee camps, both serving as fertile ground for the spread of a militant brand of Islamic fundamentalism; and a history of military intervention by outside powers.

Unquestionably, a certain sense of urgency for finding a permanent political solution to the conflict exists 
outside the Middle East as well as within the region itself. Nevertheless, the search for that solution has yielded progress only on an interim arrangement (the Gaza-Jericho plan). This study is an attempt to examine an old, seemingly unsolvable problem from a fresh perspective. The intention is to demonstrate that, for both sides, the benefits of compromise, order and cooperation engendered by the notion of common security outweigh those derived from unyielding adherence to abstract historical, moral and quasi-legal title claims on the disputed territories. 
CHAPTER I NOTES

${ }^{1}$ It should be noted that present-day Jordan was also originally included as part of the Palestine mandate assigned to Great Britain by the League of Nations at the San Remo Conference of April 1920. However, by the time the mandate was officially approved in July 1922, Britain had already unilaterally severed what was then Transjordan, placing it under a separate administration. Some right-wing Israelis thus consider Jordan as a large portion of the original Land of Israel which was already "conceded" to the Arabs. For a discussion on this point see, Raphael Israeli, Palestinians Between Israel and Jordan: Squaring the Triangle (New York: Praeger Publishers, 1991) 81-85.

${ }^{2}$ Charles D. Smith, Palestine and the Arab-Israeli Conflict (New York: St. Martin's Press, 1988) 107.

${ }^{3}$ Ibid., 147 .

${ }^{4}$ Israeli, op. cit., 104. Note: The above figure does not include the more than 100,000 Israeli Jews who were living in East Jerusalem and its environs as of 1988 .

${ }^{5}$ Mark A. Heller and Sari Nusseibeh, No Trumpets, No Drums: A Two-state settlement of the Israeli-Palestinian Conflict (New York: Hill and Wang, 1991) 100.

${ }^{6}$ Michael T. Klare and Daniel C. Thomas, eds., World Security: Trends and Challenges at Century's End (New York: St. Martin's Press, 1991) 3.

7'Ibid., 2-5.

${ }^{8}$ Thomas Risse-Kappen, "From Mutual Containment to Common Security: Europe During and After the Cold War," in Klare and Thomas, eds., op. cit., 132.

${ }^{9}$ Ibid. , 129-133. 
CHAPTER II

\section{A ZERO-SUM CONFLICT?}

Eretz Israel is an absolute entity whose essence does not depend on any political factor...An Israeli [government] which limits or inhibits the settlement of Israel by its people loses both its virtue and importance, and in the final analysis its moral and legal authority altogether...

--Rabbi Jacob Ariel, Gush Emunim ${ }^{1}$

Prior to an analysis of the concept of common security in chapter 3, this chapter first examines its antithesis: zero-sum approaches to the Israeli-Palestinian conflict. Unlike common security, which relies strictly on positivesum processes (see chapters 1 and 3), many of the title claims on the disputed territories advanced by both sides of the conflict envisage only "winner-take-all" scenarios. A positive-sum approach would ensure that the vital interests of both the Israelis and Palestinians are at least partially satisfied. By contrast, zero-sum approaches, like the one reflected in the position of Rabbi Ariel (above), insist on solutions which benefit exclusively one party at the partial or total expense of the other. 


\section{IRRECONCILABLE TERRITORIAL CLAIMS}

Why are the West Bank and, to a lesser extent, the Gaza Strip so important to Israel? Why has a sizable minority of the Israeli population for more than two decades championed the creation of faits accomplis--the Jewish settlements--in order to achieve a de facto (and, according to its interpretation, legal) annexation of this land? Israelis offer several rationales for their insistence on retaining the territories, among them strategic, historical, religious (moral), and economic.

Israel is surrounded by a hostile and embittered Arab world (with the significant exception of Egypt) and has now suffered through seven wars with its neighbors and numerous terrorist infiltrations inside its borders. Most Israelis, therefore, feel that their country requires a margin of security in the form of the West Bank to compensate for its tiny size and vulnerable shape, relatively small population and history of anguish.

A much smaller percentage of Israelis hark back to Biblical times and the covenant between God and Abraham as "evidence" of a corollary title claim to Eretz Israel, which includes both the West Bank and Gaza. Others, right-wing religious zionists, believe that withdrawal from the territories would be tantamount to forfeiture of redemption, thereby precluding the coming of the messianic age in which 
Israel is to be a "light unto nations." still others can point to the economic advantages afforded by possession of the territories, some of which have persisted even after the advent of the intifada: manpower and, to a lesser extent, markets for Israeli industries and a supplemental supply of badly needed water.

Unfortunately for the Israelis, the Palestinians can also put forth a multitude of arguments establishing title to this land. These claims, if not in all cases parallel to those advanced by their Jewish counterparts, are just as cogent. Yet in the practical sense of finding a political solution to this extremely intricate problem, what is the significance of these arguments and counterarguments about which so much has been written?

A basic criticism of those writers who approach this contentious, emotion-laden subject from a historical, moral or international legal standpoint is that they make the fundamental mistake of viewing the conflict in essentially zero-sum terms. This is due to the irreconcilable nature of the variables involved. The Israelis and Palestinians must come to understand that getting past these irreconcilable territorial claims is thus a necessary, albeit insufficient, condition for resolving the conflict. 


\section{Historical Rights}

It is inconceivable that the disposition of the West Bank and Gaza Strip could be formulated on the basis of historical rights. As scholarly and, for that matter, general interest in the Arab-Israeli conflict has swelled, a proliferation of literature dealing with Israeli and Palestinian history has occurred. One scholar, for example, recently wrote an entire text on the conflict largely because of the perceived need to produce once and for all a "satisfactory" account of Arab-Zionist relations in the pre1948 era. $^{2}$

In another well-known work, the author concludes that in the period from 1947 to 1949, the vast majority of Arabs residing in that part of Palestine which was to become present-day Israel proper had actually only recently emigrated there from other Arab lands. ${ }^{3}$ The corollary, that the Palestinians' historical claims on parts of Israel--if not on portions of the West Bank and Gaza as well--are a complete fabrication, was scathingly repudiated in a subsequent work by a Palestinian scholar. ${ }^{4}$ Nevertheless, the great ongoing debate over which people is the rightful inheritor of this land can never be settled.

Israelis by and large feel that from a strictly historical perspective, they are, at least theoretically, entitled to all of Eretz Israel due to several factors: the Biblical 
promise made to the Jewish people (the fact that it was made 4,000 years ago notwithstanding); their uninterrupted presence on this land from 1000 B.C.E. until their forced eviction by the Romans in $70 \mathrm{C.E} . ;$ their continuous collective yearning for an end to their exile and a return to Palestine; and, more recently, their conquest of the west Bank and Gaza by means of what, in their view, was a legitimate defensive war.

Diametrically opposed to these arguments is the Palestinian Arab viewpoint, summarized by Sari Nusseibeh:

Palestinians essentially believe that any bargaining with Israel over Palestinian territory is like bargaining over stolen property with the very thief who stole it by force... Unlike the Jews, who were dispossessed of a territorial (and therefore objective) continuity and who perhaps therefore compensated for this through a highly developed sense of continuous collective selfconsciousness, Palestinian Arab continuity has been objective rather than subjective. Thus, while it may be true that there is no subjective thread (until the emergence of Islam) linking the various Arab communities who lived and ruled in Palestine through history, yet this is not regarded by present-day palestinians as in any sense undermining their historical rightful claim to the country...

Not only will this debate never be resolved, it is, moreover, critical to understand that rights which derive from history, particularly ancient but also contemporary history, are indivisible and therefore leave no room for a compromise formula among the disputants. Israeli and 
Palestinian historical claims on the geographical domain in question fundamentally contradict and invalidate one another. Neither side, therefore, can concede the other's right to a national territory without essentially discrediting its own historical position.

\section{Moral Imperatives}

If no political settlement conceived on the basis of historical rights is imaginable, one could hardly envisage a solution to the conflict formulated on the basis of moral or ideological imperatives. After all, morality is even more subjective than history. The obvious question which arises, then, is, "whose morality?"

The Palestinians share an entrenched conviction that they are living under an oppressive occupation. Particularly since the onset of the intifada, the Israeli military has imposed a number of individual and collective punishments on the Palestinian inhabitants of the West Bank and Gaza which the latter regard as nothing short of a blatant deprivation of their fundamental human rights.

In an effort to quell the recurring violent disruptions of law and order in the territories spawned by the uprising, Israel has frequently resorted to harsh measures. These include: beatings; deportation; administrative detention of up to one year; demolition of the homes of suspected perpetrators of violence; military curfews; school closures; 
confiscation of personal property belonging to residents who are discovered to be in tax arrears; and the issuance of new magnetic ID cards as a means of preventing suspected troublemakers or their family members from entering Israel to work. An argument for withdrawal from the territories often heard within leftist circles in Israel is that if this subjugation of a people against its will should continue, it will inevitably tear the moral fabric of Israeli society. 6 Many Israelis, on the other hand, simply do not believe they are under any moral obligation to surrender this land to the Palestinians. Any valid moral judgment of the manner by which Israel governs the territories, they argue, must incorporate as its standard the behavior of Western democracies (let alone that of Israel's autocratic Arab neighbors) in similar conditions of war and insurrection. Israel, which has implemented specific safeguards to ensure the basic rights of the Arab residents of the West Bank and Gaza, arguably has a relatively reasonable (albeit far from perfect) human-rights record even according to this high standard. ${ }^{7}$

In addition to these safeguards, marked improvements have been made in the general quality of life of the inhabitants of the territories since 1967. Among these are: advances in agricultural technology and productivity; the chartering of six institutions of higher learning and the 
establishment of several vocational training centers for the local population; improved health services, including child immunization programs and the availability of quality medical facilities in Israel proper when necessary; and the development of infrastructure, such as electrification and roads. Both access to publicly provided services and the opportunity to improve one's standard of living have thus generally been much better satisfied since Israel's takeover of the territories. As Raphael Israeli points out, are not these two of the most fundamental of human rights in any society $?^{8}$

And what of the morality of the right-wing religious Zionists, such as Rabbis Moshe Levinger and Eliezer Waldman? This disproportionately influential sector of the Israeli population believes that withdrawal by Israel from the West Bank and Gaza strip would be contrary to God's intentions, thereby constituting blasphemy. In their view, the fact that the Jews, until 1967, did not possess control of such holy places as the Cotel and the Machpela' was the result of a tragic historical injustice. More importantly, no abstract notion of human rights for the Arab inhabitants of the territories, whom these Israelis regard as "alien" residents, can be permitted to have primacy over--and thereby undermine--the collective right of the Jewish nation to its sacred, indivisible land. ${ }^{10}$ 
It should be apparent, even from this small sampling of contradictory moral viewpoints, that those who seek to invoke a "higher" principle of morality to determine the parameters within which to resolve the conflict are only deluding themselves.

obligations Under International Law

Nor is this the sort of conflict which can be settled on the basis of widely accepted international legal or quasi-legal principles. Again, the problem is one of irreconcilably opposed perspectives and interpretations, particularly regarding Israeli sovereignty over the territories. On this core issue, Israel and the Palestinians begin from entirely different points of departure.

Successive Israeli governments since the Six-Day War have always declared as a matter of principle their compliance with the restrictions of the 1949 Fourth Geneva Convention governing occupied enemy territory (e.g., those dealing with the appropriation of private property for military purposes). Nevertheless, the Israelis have never considered themselves irrefutably obligated to do so because of what they still see as an open question of whether in fact the territories became "occupied" in 1967, as the Palestinians insist, or were "liberated" in a defensive war. ${ }^{11}$ After all, the argument goes, when these territories 
were acquired by Israel they did not belong to Jordan and Egypt, who had captured them through acts of aggression in the 1948 war.

Withdrawal from the territories (including East Jerusalem) because of international legal imperatives might be mistakenly interpreted by the international community as an admission by Israel that it has all along been in illegal occupation of what are indisputably Arab lands. No Israeli government, whether led by Likud or Labor, would ever concede even part of the West Bank and Gaza on that basis. The problem with the Israeli position, on the one hand, is that the territories could only have been "liberated" if they had definitively belonged to the modern state of Israel in the first place. Valid claims to the effect that Judea and Samaria (the Biblical names referring to the present-day West Bank) formed the heart of Ancient Israel notwithstanding, this simply is not the case at any point in contemporary history prior to 1967. True, Israel did not acquire the West Bank and Gaza through an act of aggression a la the Iraqi takeover of Kuwait or the Chinese takeover of Tibet. However, were all bilateral disputants in conflicts of this nature to embrace the sort of attitude that would portray any captured enemy territory as liberated (or, for that matter, terra nullius), political settlements would be virtually unimaginable. 
On the other hand, the Arab assertion that the entirety of the West Bank and Gaza belongs exclusively to the Palestinians seems to lose at least some of its legitimacy if one considers that when Jordan and Egypt controlled these territories, the Arabs collectively made no attempt to establish an independent Palestinian state. More importantly, absolute insistence that the territories are occupied Palestinian Arab land--including East Jerusalem, which was to be internationalized under the 1947 U.N. partition resolution--would seem to leave no room for even limited territorial compromise. In the practical sense, then, Palestinian claims differ little from right-wing Israeli declarations that the territories constitute liberated Jewish land.

U.N. Resolution 242. Nowhere can the zero-sum nature of this aspect of the conflict be better seen than in U.N. Security Council Resolution 242, or what Nadav Safran calls "that masterpiece of ambiguity."12 Adopted in November 1967 in the wake of the Six-Day War, the resolution was carefully worded so that the Arabs and Israelis could both read into it exactly what they wanted. Its preamble stresses "the inadmissibility of the acquisition of territory by war and the need to work for a just and lasting peace in which every 
state in the area can live in security." It then calls for

(i) Withdrawal of Israeli armed forces from territories occupied in the recent conflict; (ii) termination of all claims or states of beliigerency and respect for and acknowledgement of the sovereignty, territorial integrity and political independence of every state in the area and their right to live in peace within secure and recognized boundaries free from threats or acts of force.

Notably, the definite article was deliberately omitted from the resolution's clause concerning Israeli withdrawal (i.e., it reads withdrawal "from territories" rather than "from [the] territories"). Although the Arabs were assured by the soviets that the omission was insignificant, Israel read the clause to mean that it would not be obligated to withdraw from all the land which it had acquired in an act of self-defense. ${ }^{13}$ The operative phrase for Israel, moreover, was to be found not in the first, but the second clause: "secure" boundaries. The latter, in the Israeli view, could only be interpreted as requiring not insignificant revisions of the 1949 armistice lines.

While the Israelis understand that a state cannot truly have secure boundaries if, as the second clause acknowledges, they are not also recognized boundaries, their interpretation of 242 (or the Arab interpretation, depending on one's point of view) presents a seemingly insoluble dilemma. The Palestinians and each of the Arab states 
demand that Israel, at a minimum, return to the pre-1967 borders. The latter, presumably, would constitute recognized, permanent boundaries although other than Egypt, the Arabs have never offered any formal guarantees to that effect. The Israelis, however, adamantly contend that total withdrawal from the west Bank and Gaza would leave them with borders which, even if formally recognized by the Arabs, provide no strategic depth and are therefore simply not secure.

If the Israeli-Palestinian conflict cannot be settled on the basis of historical rights, moral imperatives and/or international legal obligations because of the zero-sum (i.e., irreconcilable) nature of these overlapping factors, then on what basis can it be resolved? clearly, any potential solution must at least partially satisfy the vital interests of both of the parties. Yet, certain perceived interests, it has been demonstrated, profoundly conflict with those of the adversary because they derive from one side's subjective version of history, moral doctrine, religious tenets or legal interpretation. Consequently, they can be satisfied only at the expense of the security of the adversary.

Nevertheless, other, truly vital interests exist which are not necessarily contradictory; rather, they are mutual. It is the latter which must be recognized by the Israelis 
and Palestinians (and by Israelis and Arabs generally) as having the potential to forge a common ground between them. The notion of common security, discussed in the next chapter, embodies precisely such mutual interests. 
CHAPTER II NOTES

${ }^{1}$ Rabbi Yaakov Ariel, "The Land and the State," Nekuda May 15, 1981: 3. Quoted in, Ehud Sprinzak, The Ascendance of Israel's Radical Right (New York: Oxford University Press, 1991) 119 .

${ }^{2}$ Charles D. Smith, Palestine and the Arab-Israeli Conflict (New York: st. Martin's Press, 1988). Note: See preface.

3 Joan Peters, From Time Immemorial (New York: Harper and Row, Publishers, 1984).

${ }^{4}$ Edward W. Said, Blaming the Victims: Spurious Scholarship and the Palestinian Question (New York: Verso, 1988).

${ }^{5}$ Mark A. Heller and Sari Nusseibeh, No Trumpets, No Drums: A Two-state settlement of the Israeli-Palestinian Conflict (New York: Hill and Wang, 1991) 32 .

${ }^{6}$ As an example of the argument that the status quo will inevitably erode the moral and ethical values of Israeli society, see, Simha Flapan, The Birth of Israel: Myths and Realities (New York: Pantheon Books, 1987). Flapan purports to debunk certain "myths" surrounding the creation of Israel and its aftermath in order to stimulate a new, more constructive approach to the Israeli-Palestinian conflict. Some Israeli scholars, however, view Flapan as a historical revisionist.

${ }^{7}$ For a detailed enumeration of these safeguards, see, Raphael Israeli, Palestinians Between Israel and Jordan: Squaring the Triangle (New York: Praeger Publishers, 1991) 22-26.

$$
{ }^{8} \text { Ibid., } 24 \text {. }
$$

'The cotel, which is the holiest site in Judaism, refers to the Wailing Wall of the second Temple in Jerusalem's old City. The Machpela is the Hebrew name for the traditional burial place of the Jewish patriarchs in Hebron on the West Bank. 
${ }^{10}$ For an excellent discussion on the writings of the Gush Emunim, the messianic movement of the settlers in the West Bank and Gaza, see, Sprinzak, op. cit., 107-166. See also, Ian S. Lustick, For the Land and the Lord: Jewish Fundamentalism in Israel (New York: Council on Foreign Relations, Inc., 1988) 72-152.

${ }^{11}$ For a discussion on the legal status of the territories, see, Israeli, op. cit., 20-21. For the Arab point of view, see also, Hassan bin Talal, Palestinian SelfDetermination: A study of the West Bank and Gaza Strip (New York: Quartet Books, Inc., 1981) 111-117.

${ }^{12}$ Nadav Safran, Israel: The Embattled Ally, 2nd ed. (Cambridge: Belknap/Harvard University Press, 1981) 430.

${ }^{13}$ In the end, the U.S. supported the omission of the definite article in the resolution's withdrawal clause. According to William Quandt, however, the American Ambassador to the U.N. provided assurances to the Jordanians that in return for their acceptance of 242 , the U.S. would work for a return of the West Bank to the Hashemite kingdom. For a discussion on the postwar diplomacy leading up to the drafting of 242, see, William B. Quandt, Decade of Decisions: American Policy Toward the Arab-Israeli conflict 1967-1976 (Berkeley: University of California Press, 1977) $63-68$. 
CHAPTER III

\section{COMMON SECURITY: ISRAELI-PALESTINIAN STYLE}

In the field of security we are slowly realizing that our understanding of security is too narrow in a double sense: First, it encompasses more than just military security, and second, it has to be more than just national security.

--Curt Gasteyger ${ }^{1}$

The achievement of security, whether broadly defined as in the above quotation or confined strictly to military security, can no longer be viewed as a zero-sum process. As a case in point, consider the "security dilemma" which characterized the East-West conflict prior to the institution of common security as the underlying philosophy of AmericanSoviet détente.

simply put, the security dilemma describes a scenario whereby a state's efforts to enhance its security unilaterally initiate a chain of events which, in the end, diminishes its security. Specifically, it refers to a situation of intense rivalry in which even a defensiveoriented action taken by side A (e.g., the deployment of anti-aircraft missiles) is typically perceived--or misperceived--as threatening by side B. This perceived provocation begets a "hostile" response by the latter 
directed, at least ostensibly, at the former. Side $A$, in turn, retaliates against side $B$ for its hostile act, and on it goes with each move progressively more detrimental to the security of the other.

The security dilemma, then, is engendered by a tensionladen atmosphere of common insecurity. This, in turn, can precipitate a dangerous and unending cycle of militarization in the form of an accelerating arms race, mutual distrust (perhaps accompanied and exacerbated by strategic deception), strong preemptive military imperatives and, ultimately, armed conflict.

The United States and the former Soviet Union were able to overcome this common insecurity. They did so by the realization that even with an underlying nuclear deterrence regime of mutual assured destruction (MAD), there could be only common security for both or no real security for either. Hence, the transformation of East-West arms control negotiations from a zero-sum game into a positive-sum process reversed what was a dangerous, if not entirely predictable, trend and thereby contributed to the eventual termination of the cold War. ${ }^{2}$

The concept of common security originated with the work of the Independent Commission on Disarmament and security Issues, which was formed in Stockholm, Sweden in 1980. The commission developed the concept primarily as a proposed 
alternative to the NATO-Warsaw Pact doctrine of mutual deterrence (nuclear and conventional). ${ }^{3}$ This alternative, it has been seen, was adopted (with positive results) as the underlying philosophy governing East-West relations a halfdecade later.

While the stockholm commission focused the bulk of its efforts on potential arms control strategies for the rival East-West blocs, it also stressed the applicability of the common security concept to Third world countries as well. In the view of the commission, these states, like the nuclear powers, "cannot achieve security against [i.e., at the expense of] their adversaries." "This study concurs with the latter conclusion, particularly in its applicability to the Israeli-Palestinian conflict.

The goal of this chapter, therefore, is to establish the essential elements of a common security framework for Israel and the Palestinian inhabitants of the West Bank and Gaza Strip. Such a framework, it is hoped, will help elucidate the requisites for a secure Israeli-Palestinian peace. First, however, it is necessary to provide a more detailed definition of the notion of common security. This will be followed by a brief enumeration of the variables which render the concept conducive to resolving this specific conflict. 


\section{COMMON SECURITY DEFINED}

This study defines common security as a mutual commitment to joint survival. This commitment is based on a recognition that because of an increasingly interdependent world--militarily, politically, economically and demographically--states can no longer achieve security unilaterally but rather only through the creation of positive-sum processes which lead to cooperation with one another. Two important assumptions underlie this definition. First, the security of all states is itself interdependent, particularly given a broad definition of national security (see below). Second, military force, political intimidation and economic coercion are very unlikely to be effective instruments for settling international (or intercommunal) disputes over the long run. 5

\section{Principles}

To achieve the comprehensive common security defined above, the following principles, at a minimum, must be adhered to by the parties involved: ${ }^{6}$

1. All states have a legitimate right to security regardless of their political or ideological bent.

2. Policies and actions which strive for unilateral security advantages--whether by acquiring armaments, bargaining in negotiations for mutually exclusive gains or, most dangerously, exercising military force--should be discouraged. 
3. Efforts to attain military superiority vis-à-vis adversaries should cease and be replaced by the pursuit of parity between the parties. Parity, however, must take into account such things as the parties' disparate geostrategic circumstances and disparities of human and material resources. Adversaries, for example, need not be required to have identical military force structures and levels.

4. The adversarial relationship between the parties should gradually be replaced by a political atmosphere conducive to the normalization of peaceful relations. of paramount importance is the need to establish bilateral links (e.g., political, economic) which will reinforce interdependence, thereby creating for both sides a vested interest in the durability of the settlement of the conflict.

Several of the major attributes of the American-Soviet rivalry which made the common security alternative so suitable for helping to wind down the East-West conflict exist in some form in the Israeli-Palestinian relationship as well. First, the vital interests of the Israelis and the Palestinian Arabs of the territories, like those of the nuclear superpowers, are inextricably bound up with one another. Thus, immediate-term unilateral security gains by one side at the expense of the other are shortsighted and are likely to reduce security over the long run. Second, the Israeli-Palestinian rivalry is characterized by a great degree of animosity and distrust, even more deep-rooted than that which existed between the U.S. and former Soviet Union. Consequently, perceptions of one another's intentions play a significant role in the rivalry and must therefore be taken 
into consideration in any proposed solution of the conflict. Third, there exists a reciprocal threat to each other's vital interests. In other words, each side is vulnerable in terms of the multiplicity of credible threats the other side poses to its national well-being. Neither the Israelis nor the Palestinians, therefore, can feel truly secure as long as either one remains a perceived threat to the other. ${ }^{7}$

The Israeli-Palestinian conflict contains another significant variable, one which did not even exist in the superpower rivalry: the struggle is for possession of and sovereignty over the same geographic domain. clearly, it is this unique factor, more than any other attribute of the rivalry, which renders the common security concept highly appropriate for resolving the conflict.

\section{What is National Security?}

The question here really is: What is meant by security in the notion of common security? Michael Klare and Daniel Thomas, Harold Brown, and Daniel Kaufman et al. all argue that security can no longer be viewed within the narrow confines of physical security alone (i.e., strong military defense against enemy invasion).$^{8}$ Rather, the concept of security must be expanded to include all major threats or perils to the national welfare whether they endanger national borders or a national territory, the national, 
regional or global economy, a vital economic resource (e.g., water), intrasocietal stability and order, or a national culture.

In its final report, the Independent Commission on Disarmament and Security Issues also offered an expanded definition of security:

Clearly, a secure nation' is one that is free from both the fact and the threat of military attack and occupation, that preserves the health and safety of its citizens, and generally advances their economic well-being. There are also less tangible dimensions to security...all nations want to be able to remain true to the principles and ideals upon which their country was founded, free to chart futures in a manner of their own choosing. ${ }^{10}$

The notion of common security, then, must be comprehensive for it to be instrumental in the formulation of a solution to the Israeli-Palestinian conflict. That is, in order to underpin a stable Israeli-Palestinian peace, this concept must be applied to the entire range of vital security interests of both peoples.

What are these long-term security interests? The vital interests of the Israelis and the Palestinians, as they are defined in this study, are not at all dissimilar. More importantly, they are interdependent and thereby inextricably linked to one another. It is therefore essential to keep in mind that although each side's security interests 
can be enumerated separately (below), they do not exist in a vacuum.

Neither the Israelis nor the Palestinians are totally unequivocal about their vital interests regarding the ultimate disposition of the Israeli-administered territories. On the one hand, significant segments of the Israeli population endorse the notion of a Greater Eretz Yisrael (i.e., pre-1967 Israel plus the West Bank and Gaza Strip). On the other hand, the official PLO leadership has in the past been deliberately ambiguous about the fine line between an intifada to shake off the occupation and armed struggle to "liberate" all of Palestine, which includes Israel proper in addition to the territories.

Most Israelis would agree, however, that their vital security interests would be served by the following: 1) first and foremost, permanent borders which provide Israel with a margin of security to ensure its national survival and which are recognized by the international community, the Arab world in particular; 2) the perpetuation of Israel's Jewish character in conjunction with its existing democratic system of governance; 3 ) the minimization of the risk of internecine Jewish strife, even violent civil war, engendered by deep societal cleavages; 4) a level of economic growth which enables the country to allocate a sufficient share of its national resources to the 
absorption of Jewish immigrants, education, health care, housing and other infrastructure, and capital investment in industry; and 5) a perpetually adequate supply of water, the Middle East's scarcest vital resource.

The Palestinians, at a minimum, insist upon: 1) an affirmation by the international community of their right to self-determination, whose only means of fulfillment is the creation of a sovereign political entity in what they consider to be Palestinian territory now controlled by Israel; 2) security against external military threats, including those from other Arab states; 3) the minimization of the prospects for internal social upheaval within what has for decades been a fragmented Palestinian Arab community (i.e., internal stability); 4) economic viability, enabling them to build adequate infrastructure, invest in modern industrial plant and resettle, feed, house and educate the hundreds of thousands of Palestinian refugees presently dispersed throughout the Arab world who would wish to reside in their homeland; and 5) a sufficient long-term supply of water for industry, irrigation and household use. 


\section{MILITARY SECURITY V. SELF-DETERMINATION}

No resolution of the Israeli-Palestinian conflict is conceivable unless, first and foremost, it is perceived by the Israelis as safeguarding their military (physical) security while at the same time satisfying the Palestinians' demand for political self-determination. of course, the ultimate question posed by many Arab-Israeli scholars is whether these two requisites for a settlement are compatible (positive interdependence) or mutually exclusive (zero-sum in nature) .

Perhaps no other country in the world is as obsessed with its physical security--indeed its national survival--as the state of Israel. Seen by its Arab neighbors as the last vestige of insufferable Western imperialism and having endured a history of war, terrorism and intermittent international isolation, Israel has had no other choice but to orient an unusually large portion of its foreign policy and resources (human as well as material) toward military security.

This fixation on national defense has stemmed from two factors in particular: the enormous disparity of resources between Israel and its Arab enemies and, at least until June 1967, the former's highly exposed geostrategic position. Underlying the latter of these two problems are Israel's 
small size, vulnerable geographic configuration and, most importantly, over-concentration of its Jewish population and industry in relatively minute, well-defined territorial pockets. Specifically, two-thirds of its population and eighty percent of its industry are located along the Sharon, a narrow coastal plain whose maximum width is a mere sixteen miles!

Even so, the Israelis' perception of vulnerability seemed to have been alleviated by the primary outcome of the 1967 Six-Day War--the appendage of the conquered Arab territories. The addition of the west Bank and Golan, for example, gave Israel the sense that it had gained sufficient strategic depth to enable it to contain an Arab armored invasion from the east and sufficient warning time to permit it to defend against a surprise Arab attack by air. ${ }^{11}$

Israeli military strategists believe that, even with today's widespread ballistic missile technology, the dominant form of warfare which determines political outcomes is still the movement of conventional land armies. Thus, the strategic importance of the territories has not, in their view, diminished. ${ }^{12}$ This is so despite Israel's nuclear arsenal, presently estimated at over 200 warheads. ${ }^{13}$ Louis Beres and Yohanan Ramati argue, for example, that over the long run, Israel's nuclear arsenal cannot continue to serve as an effective deterrent against a full-scale conventional 
invasion by Arab land forces. ${ }^{14}$ Indeed, Syria, it is reasonable to assume, has already developed a potential counter-deterrent to an Israeli nuclear attack by means of its highly destructive chemical weapons capability.

significantly, Israel has now officially endorsed the concept of a future nuclear-free zone in the Middle East. ${ }^{15}$ This change in outlook undoubtedly stems from an awareness that a mutual assured destruction (MAD) regime among Israel and any future Arab nuclear states would likely not be feasible. That is, Israel's small size and overconcentrated Jewish population would substantially undermine the credibility of a retaliatory second strike capacity. Clearly, the corollary is that the topographical advantages and strategic depth afforded by the west Bank (and the Golan) are indispensable to Israel as defensive military assets.

Opposite this position that Israel requires the territories for military security is what Matti steinberg refers to as "the centrality of the territorial principle in the definition of Palestinian identity."16 Palestinians distinguish themselves from other Arabs solely by their territorial connection to the land they call palestine--the area encompassing not merely the West Bank and Gaza Strip but Israel proper as well. This definition of identity is clearly stated in article 5 of the 1968 Palestinian National 
Covenant, which reads: "The Palestinians are those Arab nationals who, until 1947, normally resided in Palestine regardless of whether they were evicted from it or have [sic] stayed there." 17

Particularly problematic for the Israelis is the concomitant desire of the Palestinians to translate their distinct identity into sovereignty and political independence. The territorial imperative in the Palestinian conception of political self-determination is wellentrenched and non-negotiable. It is thus difficult to envisage a scenario whereby Israel could retain the West Bank and Gaza without denying the Palestinians the very essence of their national existence.

Israeli decision-makers might encounter great difficulty reaching a consensus regarding which parts of the West Bank and Gaza, if any, they could (or could not) afford to relinquish for the sake of an independent or autonomous Palestinian homeland. Clearly, the fundamental question which they would ultimately have to confront is: Does retention of this specific territory truly enhance Israel's security, if, at the same time, it fuels the Palestinian perception that their long-term prospects for selfdetermination (indeed, national survival) are being irreparably undermined? 
As has been seen, the importance of the West Bank, and, to a lesser extent, the Gaza strip for Israel's defense can in no way be dismissed. Yet, one must consider whether the security risks posed by additional territory are not greater than the benefits they accord given the existing, potentially explosive circumstances in those areas and in the Arab world at large.

There is no clear-cut answer to this question; in fact, the same factor may have contradictory implications. On the one hand, Israel's possession of the West Bank enhances its tactical position by giving it a formidable security barrier to help deter an Arab assault on its eastern front. The West Bank also serves as a local base from which Israel can effectively counter Palestinian terrorist operations. on the other hand, it is Israel's very retention of former Arab territory which increases the Arab states' collective incentive to make war against the Jewish state. More importantly, continued Israeli rule is certain to inflame and radicalize further an indigenous Palestinian population which demands self-determination and is already being pushed to its limit by a widespread perception that the occupation is becoming more and more oppressive. In this context, the territories ostensibly improve Israel's margin of security while at the same time increasing the probability of war and instability over the long run! 
The notion of common security would seem to dictate the need to search for a realistic alternative whereby Israel would at least retain the security advantages provided by the West Bank even were this territory to become a sovereign Palestinian political entity. Such an alternative could translate into Israel annexing some of the strategically important parts of the West Bank (and possibly Gaza) and returning the rest to Arab control. Another option would be for Israel to establish security arrangements--perhaps jointly with the Palestinians--in designated areas of the territory to be evacuated. In the latter scenario, Israel would relinquish sovereign control of the territories to the Palestinians, thus acceding to their demand for political selfdetermination. However, due to the nature of demilitarization schemes and multinational force deployments--if not an actual Israeli extraterritorial military presence--such sovereignty would of necessity be limited. These and other scenarios are evaluated in more detail in the concluding chapters of this study.

SUPPORT FOR A SETTLEMENT AND INTERNAL STABILITY

The concept of common security attempts to address the adversaries' mutual obsession with one another's intentions engendered by a deep-rooted distrust between long-time enemies. In the negotiating process, each side naturally 
raises doubts about the willingness (or ability) of the other to abide by the prospective terms of a permanent settlement. It is in the interests of both, therefore, to ensure that the outcome of the negotiations will be an agreement which will prove acceptable to the vast majority of their respective populations.

For one thing, neither side is likely to ratify a peace treaty knowing that a sizable or highly influential sector of the adversary's population refuses to support the settlement. More importantly, once an agreement has been implemented, excessive concern with merely the intentions of those on the other side who openly aim to sabotage the settlement could lead the threatened party to respond preemptively by military means. The two sides thus could easily find themselves back in the throes of the very security dilemma which they sought to resolve.

There is a related, potentially more serious dimension of this aspect of security. Specifically, neither the Israelis nor the Palestinians can feel secure unless both societies enjoy internal stability. Internal destabilization not only threatens the state or society in which it occurs, it commonly threatens neighboring societies as well (i.e., it undermines regional stability). It is critical, therefore, that the concessions which will inevitably be made by each side to achieve a political 
settlement not deepen existing societal cleavages over the question of the final disposition of the West Bank and Gaza. Any further exacerbation of the internal tensions which are presently a salient feature of both societies could ultimately lead to civil war, thereby threatening the stability of the entire area.

It is not beyond the realm of possibility, for example, that an Arab Palestine in the West Bank and Gaza could become another Lebanon, totally paralyzed by sectarian violence and anarchy. Presumably, a sovereign Palestine would be governed by the PLO, yet the latter is by no means a monolithic organization. The divisions within that body, though papered over at times, are many and serious. A permanent settlement between Israel and the Palestinians might prove unacceptable to the radical rejectionist elements within the PLO. These factions could then secede from the organization and attempt to undermine the agreement by means of terrorist operations inside Israel or within the borders of the incipient Palestinian entity.

There exists, moreover, several Palestinian groups operating outside the PLO umbrella which oppose in principle not only the mainstream Fatah wing of the organization, but, from time to time, its radical secular factions as well. These include Hamas and the Islamic Jihad, the Islamic fundamentalist groups which openly call for a holy war to 
eradicate the Jewish presence from all of Palestine. It is not inconceivable, therefore, that palestinian political self-determination could gradually be subverted by violent internecine war between moderate and radical secular blocs, between secular and fundamentalist blocs, or both. ${ }^{18}$ From Israel's point of view, its security would clearly be adversely affected if it were forced to contend with a second "hot" border.

In Israel, too, a political settlement involving territorial compromise could trigger widespread violent opposition, particularly among (but not limited to) the settler community. One scholar describes in detail what such a crisis would potentially entail:

...repeated demonstrations by hundreds of thousands of Jews, violence against both Jews and - Arabs, challenges to the authority and legitimacy of the government, a host of rabbinical decrees opposing the government's intentions [regarding territorial withdrawal], the creation of scores of new illegal settlements, threats of civil war, a sudden influx of militantly ultranationalist Diaspora Jews and...attempts at spectacular actions such as the destruction of the Muslim shrines in Jerusalem. ${ }^{19}$

While the above scenario may be somewhat overstated, there is no denying that Israel is deeply divided over key territorial and ideological issues. Thus, the threat of civil war cannot be dismissed. Not only would this threat clearly imperil the security of Israel, it would, moreover, 
endanger the security of the incipient palestinian entity established in territory which was being evacuated (this assumes, of course, that implementation of the settlement could progress to the withdrawal stage in the first place). of particular concern to the Palestinians is the likelihood that a Jewish civil war, were it to occur, would be centered in the West Bank with the violence quickly spreading to the densely populated Arab enclaves.

The concept of common security, then, requires that the terms of Israeli-Palestinian coexistence be supported on each side by a strong majority whose interests in a secure peace are firmly entrenched. Such permanent interests, moreover, must move these majorities to neutralize quickly the threat of dissenting factions who strive to sabotage the settlement. Otherwise, internal discord and the resultant destabilization (within either society) is likely to undermine the security of both the Israelis and the Palestinians.

\section{THE DEMOGRAPHIC THREAT}

Common security, it has been seen, operates on the basis of a recognition among the adversaries that neither of them can unilaterally achieve security at the expense of the other. This is because the adversarial relationship is characterized by mutual threat and inextricably linked vital interests. There exists a fundamental and unique sense in 
which this notion holds true for the Israelis, the overwhelming majority of whom would regard their state's Jewish character and democratic form of government as indispensable elements of security.

Even if it could be proven that the appendage of the territories provides Israel with a greater degree of military (and psychological) security, their continued retention is problematic. Specifically, it forces the Israelis to confront a fundamental dilemma concerning the ultimate nature of their country: Is it to be Jewish and democratic? Jewish (at least in terms of the majority of its citizenry) but no longer democratic? or democratic but no longer Jewish?

The only way for Israel to annex the West Bank and Gaza outright and remain a democracy would seem to be by eventually forfeiting its Jewish character. Specifically, a democratic state in all of Eretz Israel would entail granting the Palestinian inhabitants of the territories full political rights, including citizenship and the concomitant right to vote. Because of their much higher birth rates, Arab citizens of a Greater Israel would likely outnumber Israeli Jews before the middle of the next century. ${ }^{20}$

The late Rabbi Meir Kahane, a right-wing extremist, warned of the potential implications of precisely such a 
"free" Arab majority in Israel:

\begin{abstract}
Does "free" mean an equal right for an Arab majority in the Knesset [the Israeli parliament] to decide that the state be named "Palestine?" That the Law of Return, which today allows Jews, not Arabs, automatic entrance and citizenship, be canceled? In short, could the Arabs of the Jewish state...be free and equal to...democratically bring an end to zionism and to the Jewish state? ${ }^{21}$
\end{abstract}

Arguably, there is no other way in which the Palestinians pose a more serious potential threat to Israel than they do in regard to its Jewish and, indirectly, democratic nature. Will the Palestinian question eventually force Israel to make this choice between its Jewishness and its democratic system of government? Not necessarily. But under a framework of common security, Israel clearly cannot remain a Jewish and democratic state if it attempts to do so at the expense of Palestinian political self-determination.

\title{
COMMON ECONOMIC SECURITY
}

In today's world, the concept of security must include protection against threats to the economic well-being of a state or society. Indeed, the national security of a state on the verge of economic collapse (e.g., Russia) might be more endangered than if it were threatened by military invasion. Still, an expanded definition of security is not in itself sufficient reason for economic security ${ }^{22}$ to be included under the umbrella of common security. Other variables must also be present, as they are in this specific conflict. 
For the Israelis and Palestinians, the envisioned common security framework must take into account economic threats. There are four major reasons for this in addition to the expanded definition rationale: 1) the continuation of the Israeli-Palestinian conflict clearly threatens both sides' economic well-being; 2) the Israeli and Palestinian economies are interdependent, albeit on an uneven basis; 3) profound economic instability within one society, particularly a new sovereign Palestinian entity, could have an inimical effect on the physical security of the other; and 4) the creation of a common economic market among Israel and the Palestinians--as well as the neighboring Arab states--would be generally beneficial to all parties.

\section{Costs of the conflict}

The most detrimental economic cost of the ongoing Israeli-Palestinian (and Arab-Israeli) conflict is the distortion of the social and economic structures of the adversaries. This enormous opportunity cost, along with the inevitable direct costs of the conflict (below), is a primary contributor to economic stagnation. For both sides, a continuation of the struggle means that, contrary to the notion of common economic security, there are less resources available for those things which foster economic development: education, housing, capital investment in 
industry and infrastructure, and technological innovation. Consequently, Israel, the Palestinians and Israel's Arab neighbors will continue to be economically--and thereby politically--dependent on outside powers and resources.

The Palestinian intifada against the Israeli occupation provides the most salient evidence of how the conflict poses a danger to the economic welfare of both sides. During its first eighteen months in particular, the intifada produced considerable economic repercussions in Israel. ${ }^{23}$ In June 1989, Israeli Finance Minister Shimon Peres (now the foreign minister) estimated that the uprising had already cost Israel, directly and indirectly, between $\$ 2.25$ and $\$ 3$ billion. ${ }^{24}$ In 1988, which witnessed the peak of the intifada, the Israel Defense Forces (IDF) deployed an average of 10,000 soldiers per day in the territories at a cost of $\$ 225$ million. ${ }^{25}$ Furthermore, mandatory reserve duty during that year doubled to an average of fifty days per man. ${ }^{26}$ This unusually large mobilization of reservists, normally a wartime measure required by Israel due to its relatively small population, caused a sharp and widespread decline in production. Hardest hit were the labor-intensive sectors of the Israeli economy, such as construction, agriculture and textiles (these sectors were also hurt by Palestinian worker absenteeism due to strikes and military curfews)..$^{27}$ 
Two other areas which were adversely affected by the intifada in its peak year were Israeli exports to the West Bank and Gaza and tourism. Sales of Israeli industrial goods to the territories fell in 1988 by $\$ 600$ million, or seventy percent ${ }^{28}$; the sale of agricultural goods fell by sixty percent. ${ }^{29}$ This precipitous decline in exports to the territories was primarily the result of a Palestinian boycott imposed on Israeli commodities for which a local substitute existed. Revenue from tourism, which Israel depends on as a major source of foreign currency income, decreased by $\$ 120$ million (approximately fifteen percent) as tourists stayed away from what was perceived to be an unsafe region. ${ }^{30}$ consequently, Israel, already saddled with a burdensome foreign debt, was forced to borrow even more from external sources.

Although the magnitude of the costs suffered by the Israeli economy due to the intifada lessened after mid1989,31 it would surely increase again if a renewed uprising were to recapture or surpass the intensity level it possessed in its first two years. It is readily apparent that if the current Israeli-Palestinian bilateral negotiations do noţ continue to yield concrete political gains for the Palestinians, they will become further frustrated and radicalized. Having failed in the diplomatic arena, they are likely to sense that they have nothing to 
lose by resorting to increasingly widespread violent resistance against the occupation. Were such a development to occur, the economic costs to Israel would clearly be substantial.

The Palestinians, too, have suffered economically as a result of the conflict. By the middle of the intifada's second year, the disruption of economic activity in the territories caused in large part by Israeli-imposed economic pressures, ${ }^{32}$ intermittent strikes, vandalism against strike violators and self-imposed boycotts resulted in a severe economic crisis. Private income fell sharply. The ensuing decline in private consumption forced many Arab shopowners, particularly in East Jerusalem, Ramallah and Bethlehem, out of business, and a situation of economic scarcity developed throughout the territories. This, in turn, led to a noticeable reduction in the Palestinian standard of living, by as much as 35 percent in some sectors. ${ }^{33}$ The inevitable conclusion drawn by this study is that if the Palestinians choose eventually to renew--and escalate--their uprising against the Israelis, they can do so only by inflicting considerable economic damage on themselves.

\section{Interdependence}

According to one definition, economic interdependence "is present when there is an increased national sensitivity [actual or perceived] to external economic developments." ${ }^{34}$ 
In a general sense, then, increasing economic interdependence means that there are more and more ways by which external forces and actors, like those of a neighboring state, may affect national economic conditions. Theoretically, the greater the degree of interdependence between the economies of two societies, the higher the probability that the poor performance of one will negatively influence the performance of the other. Interdependence theory, therefore, is compatible with the concept of common economic security: neither side can enjoy a high level of economic security unless both do.

To be sure, Israel relies on the territories as a captive export market (sixteen percent of total Israeli exports in 1987, prior to the outbreak of the intifada ${ }^{35}$ ) and a source of cheap labor for the labor-intensive sectors of its economy (forty percent of the Palestinian work force in $1987^{36}$ ). Thus, a significant drop in Palestinian private consumption due to recession, for example, could hurt Israeli exporters of elastic goods, such as plastics, wood products, cement and electric power. Nevertheless, Israel's dependence on the economy of the territories pales in comparison to Palestinian economic dependence on Israel. Ties to Israel, moreover, are currently as large a proportion as ever of the total Palestinian economy, civil resistance in the territories notwithstanding. ${ }^{37}$ 
Much of the Palestinian economic dependence on Israel has been the result of a deliberate Israeli strategy to make the economy of the territories, particularly the agricultural sector, fit into the Israeli economy. Israel dominates Palestinian trade flows by providing almost all imports into the territories (including industrial raw materials and manufacturing components without which they could not survive economically) and by purchasing eighty percent of their exports. ${ }^{38}$ Furthermore, employment in Israel continues to be the main source of income for both the west Bank and Gaza. ${ }^{39}$ Consequently, fluctuations in the performance of the Israeli economy have an immediate impact upon the health of the Palestinian sector.

Between 1981 and 1985, for example, with Israel's economy in deep recession and the inflation rate reaching triple digits, the West Bank and Gaza entered into a period of severe economic stagnation. Nearly all of the Arab inhabitants of the territories suffered. The Palestinian agriculture growth rate plummeted as productivity fell sharply. Palestinian consumers were hit with price increases of as much as 500 percent. Those who worked in Israel (in 1984, 32.5 and 46 percent of the West Bank and Gazan labor forces, respectively) saw their earlier benefits of increased incomes completely eroded by Israel's currency devaluations and high inflation. ${ }^{40}$ 
Other external factors, which underlay Palestinian economic dependence on certain Arab states in addition to Israel, exacerbated this misery. For example, falling oil prices and the 1984 recession in the Arab countries curtailed the abundant employment opportunities abroad for Palestinian university graduates, thus contributing to increasing unemployment locally. The slowdown in the Jordanian economy, which in the early 1980's purchased nearly half of all Palestinian exports, significantly reduced the demand for agricultural goods from the territories. ${ }^{41}$ Though specific circumstances may have changed since this period, the overall situation is unchanged today: the Palestinians cannot achieve a sufficient level of economic security unless the economy of Israel and of the region in general are healthy. This will hold true even if the Palestinians attain political selfdetermination.

\section{Economic Instability}

Economic insecurity within a new sovereign Palestinian entity could translate into physical insecurity for the Israelis. In other words, it is in Israel's best interests to promote to the extent possible not only its own economic growth, but the development of the Palestinian economy as well. For one thing, an economy plagued by high unemployment and a sharply decreasing standard of living can 
lead to internal social and political upheaval, the precise sort of environment in which militant, anti-Western Islamic fundamentalism seems to thrive. Such civil strife and religious extremism, in turn, often pose a threat to the security of the immediate region and beyond (see also, support for a settlement and Internal stability, above).

Furthermore, as Mark Heller notes, one major obstacle to a Palestinian entity's "capacity to sustain a nonbelligerent posture may be economic." 42 A self-governing Palestinian authority unable to satisfy the economic needs of the inhabitants of the territories might feel compelled to renew or condone terrorist activity against Israel, attempting either to divert domestic discontent or acquire some economic advantage (e.g., water or cultivatable land). To be sure, profound destabilization within the Israeli economy could, in a similar way, ultimately threaten the vital security interests of the Palestinians. This would be particularly true if a right-wing nationalist party, like the Likud, were in power. Nevertheless, the greater concern here is with the threat of Palestinian economic instability because of the numerous economic challenges the Palestinians would face upon achieving political self-determination in whatever form. Among the most serious difficulties would be: 1) the scarcity of natural resources, including domestic energy sources, in the West Bank and Gaza; 2) the 
restricted nature of the Palestinian domestic market; 3) a high rate of natural increase among the Arab population of the territories and the resultant strain on resources and infrastructure; 4) a limited capacity to absorb refugees who would immigrate to the Palestinian homeland; and 5) likely continued economic dependence on Israel.

\section{Common Economic Market}

Clearly, a common security framework among the Israelis and Palestinians must include economic security. In addition, it should do so in a manner that creates for both sides a vested interest in peace, which, in turn, would be one of its primary reinforcement mechanisms. Perhaps the surest way to establish such a permanent mutual interest in the durability of a political solution is through the creation of a common Economic market, initially among Israel, the West Bank and Gaza, and possibly Jordan. Later, the market could be expanded to include the rest of the Levant--Egypt, Lebanon and Syria.

Admittedly, a political settlement is likely to have a negative impact on certain sectors within the economies of the area (e.g., those related to present military consumption). Nevertheless, the long-term benefits of peace and economic cooperation should outweigh the short-term costs of the post-settlement structural transition which 
these economies would have to make. The socio-economic advantages of a common market include: ${ }^{43}$

1. The creation of economies of scale, which the countries of the Levant (except Egypt) currently lack due to their relative smallness in terms of population, size of markets and purchasing power.

2. The complementarity of production inputs from diverse partners, including labor, technology and marketing infrastructure. The combining of these inputs would a) enable the local economies to perform advanced processing of resources presently exported as raw materials (and thereby extract the value added); b) enhance the ability of these economies to compete effectively in international markets.

3. The maximization of income throughout the region. Well-established economic theory and empirical observation have established that, in general, income is maximized by free trade and the free flow of capital and labor.

4. The attraction of foreign investment. Because regional economic cooperation both reflects a commitment to and reinforces the permanence of the conflict's settlement, a common market approach would foster regional stability and thereby help attract needed foreign private capital.

5. The stimulation of joint ventures, many of which would be directed at resolving serious region-wide problems. Potential areas of cooperation include desalination, water conveyance and irrigation, energy, the environment, transportation, communications and tourism.

Patrick clawson notes that such benefits are greatest when the economies of the partners are strong in divergent spheres. Because they are so dissimilar, the Israeli, Palestinian and Jordanian economies in particular could profit substantially from the creation of a common market. ${ }^{44}$ 
Most importantly, with today's global trend of forming common markets (e.g., the European Community, North America and Southeast Asia), it would seem that the region's only means of competing successfully in international markets is through advanced economic cooperation.

\section{COMMON WATER SECURITY}

Under the domain of economic security must be included what this study refers to as common water security: a replenishable supply of water sufficient to meet the industrial, agricultural and household needs of both sides. Water is the Middle East's scarcest vital resource; indeed, Jordan's King Hussein recently predicted that the region's next war would emanate from a dispute over water. ${ }^{45}$ Because of its importance, therefore, water will be discussed separately here.

The requirement that an Israeli-Palestinian and wider Arab-Israeli common security framework take into account water security stems from a dangerous combination of factors: 1) the overexploitation and resultant acute shortage of the area's limited water resources, almost all of which reside in two or more national territories; 2) runaway population growth, particularly among the Arabs; 3) an almost total lack of cooperation between the disputants (and between the Arab states themselves) regarding the sharing of 
water resources; and 4) with specific regard to the Israelis and Palestinians, absolute Israeli control over the usage of water whose source is the large subterranean aquifers wholly or partially located in the West Bank.

At present, water demand in the area encompassing Israel, the territories and Jordan exceeds supply by 20-50 percent. ${ }^{46}$ According to projections based on current demographic and economic trends, Israel alone could face an annual water deficit of as much as 800 million cubic meters (mcm) by the end of the decade. ${ }^{47}$ Moreover, once the population of the region currently fed by those water resources between the Mediterranean Sea and Jordan River reaches fifteen million 20-30 years from now, supply will be sufficient for drinking water only. That is, in Israel, Jordan, the territories and southern Syria, there will be no fresh water for agriculture from these sources. ${ }^{48}$

With insufficient water in the area to meet the needs of both the Israelis and Palestinians, the situation is clearly untenable over the long run and may already be so for the Arab inhabitants of the territories. This is because the Israelis, including the Jewish settlers in the West Bank and Gaza, receive an enormously disproportionate share of the total water resources under Israeli control (over three times more than the palestinians on a per capita basis). ${ }^{49}$ Israeli overexploitation of West Bank and Gazan 
water resources in particular has produced a general lowering of the water table.

The over-pumping of wells in Jewish settlements not only has severely depleted the amount of water available to the Palestinian population in some locations, it has also noticeably reduced the quality of the water in general. As long as the over-pumping continues, salt-water seepage into groundwater sources will increase, eventually rendering the water irreversibly unusable for most purposes. In fact, Palestinian agriculture has in some cases already suffered significant losses as a result of Jewish overexploitation. ${ }^{50}$

Despite Israel's control of the water resources, the Israelis will not enjoy water security as long as they continue to deny it to the Palestinians. For one thing, the Palestinians will become increasingly embittered and hostile if the situation is permitted to worsen much further. Second, the more the Israelis neglect Palestinian agricultural water needs, the heavier the losses this critical sector of the territories' economy will inevitably suffer. The resultant decline in income and increase in unemployment, particularly in the depressed rural areas, will contribute to more economic instability and the further radicalization of an already frustrated population. (Similarly, the Palestinians cannot expect to attain water security at the expense of Israel. Because Israeli 
agriculture in the densely populated costal plain is highly dependent on the West Bank aquifers, Israel is unlikely to tolerate a future scenario in which a sovereign or autonomous Palestinian authority refuses to share water resources.)

The long-term solution to the region's acute water shortage requires bilateral and multilateral cooperation among Israel, the Palestinians and Israel's Arab neighbors. That is, only through compromise and cooperation will the disputants be able to resolve the problem of having to allocate equitably a scarce vital resource to different political entities, each claiming exclusive control over the usage of that resource. Ultimately, the parties will have to implement a comprehensive regional water regime which likely would institute the import of unutilized water resources (e.g., those in Lebanon and Turkey), joint irrigation networks, joint desalination facilities and mandatory recycling of urban water. Cooperation in the allocation of water would create an immensely important stake in an Arab-Israeli common security framework, which, in turn, would be one of its principal safeguards. ${ }^{51}$

To summarize, this chapter has attempted to demonstrate that a future Israeli-Palestinian political settlement will have to institute a comprehensive notion of common security as its underlying conceptual framework. In other words, any 
proposed solution of the conflict should be evaluated by the degree to which it incorporates the following elements:

1. A degree of physical security sufficient to ensure the national well-being of both sides. For Israel in particular, this means permanent borders which provide an ample margin of strategic depth and which are recognized by the Palestinians and the neighboring Arab states.

2. Palestinian political self-determination consisting of some form of sovereign control over territory now controlled by Israel.

3. Acceptance of the settlement by a strong majority on both sides, each with firmly entrenched interests in the durability of peace and normalization. of particular importance is the need to ensure that the settlement does not seriously exacerbate existing societal divisions over the question of the final disposition of the West Bank and Gaza Strip.

4. The retention of both Israel's Jewish character and democratic system of governance.

5. Common economic security, enabling the Israeli and Palestinian economies to avert the direct and indirect costs of the conflict and shift resources to those things which promote mutual economic development. over the long run, economic growth can be maximized by the creation of a common market among the former adversaries.

6. A permanent supply of water sufficient to meet the industrial, irrigation and household needs of both sides. 
CHAPTER III NOTES

${ }^{1}$ Curt Gasteyger, "New Dimensions of International security," Washington Quarterly 8.1 (1985): 90.

$2^{2}$ Thomas Risse-Kappen, "From Mutual Containment to Common Security: Europe During and After the Cold War," in Michael T. Klare and Daniel C. Thomas, eds., World Security: Trends and Challenges at Century's End (New York: St. Martin's Press, 1991) 129-133.

${ }^{3}$ Independent Commission on Disarmament and security Issues, Common Security: A Blueprint for Survival (New York: Simon and Schuster, 1982).

${ }^{4}$ Ibid., XV.

${ }^{5}$ For an excellent discussion on these points, see, ibid., 1-13.

${ }^{6}$ For a synopsis of the original common security principles as defined by the stockholm commission, see, ibid., 8-11.

${ }^{7}$ Perceived threats and the reaction to them played an important role in the U.S.-Soviet rivalry. For an account of the process by which a spiral of threat perception seemed to increase the risk of war between the superpowers during the first three decades after World War II, see, Quincy Wright, A study of War, 2nd ed. (Chicago: University of Chicago Press, 1965) 1506-1508 and 1512-1513.

${ }^{8}$ See, Klare and Thomas, op. cit., 3; Harold Brown, Thinking About National Security: Defense and Foreign Policy in a Dangerous World (Boulder: Westview Press, 1983) 1-9; Daniel J. Kaufman, Jeffrey S. McKitrick and Thomas J. Leney, U.S. National Security: A Framework for Analysis (Lexington: Lexington Books, 1985) 3-10.

${ }^{9}$ While the Palestinians have never possessed sovereignty in the form of a state of their own, the international community recognizes them as a nation.

${ }^{10}$ Commission on Disarmament, op. cit., 4 . 
${ }^{11}$ For a discussion on the basic strategic importance of the West Bank, see, Aryeh Shalev, "Security Dangers from the East," Jerusalem Quarterly 30 (1984): 132-135 and 140-144; Mark A. Heller, A Palestinian State: The Implications for Israel (Cambridge: Harvard University Press, 1983) 12-16; Nadav Safran, Israel: The Embattled Ally, 2nd ed.

(Cambridge: Belknap/Harvard University Press, 1981) 224-227.

${ }^{12}$ In fact, topographically advantageous defensive lines have become even more important due to today's ballistic missile technology. A missile attack on Israeli call-up centers and reserve-unit stores could significantly delay the 48-hour mobilization of reserves on which the small Israeli standing army so desperately depends in times of crisis. Thus, severely outnumbered Israeli ground forces on the eastern front would have to hold out against the enemy's armored columns for a longer period of time. The significance of a territorial buffer protecting Israel's vital coastal plain can readily be seen. For a discussion on this aspect of the strategic importance of the West Bank and Golan, see, Dore Gold, "Great Expectations," Jerusalem Post week ending 8 Feb. 1992, international ed.: 9.

${ }^{13}$ Robert E. Harkavy, "After the Gulf war: The Future of Israeli Nuclear Strategy," Washington Quarterly 14.3 (1991): 162 .

${ }^{14}$ Louis René Beres, "Israeli Security in a Changing World," Strategic Review 18.4 (1990): 14-16; Yohanan Ramati, "Israel and Nuclear Deterrence," Global Affairs 3 (1988): 179-184.

${ }^{15}$ Israel's support for a future nuclear-free zone in the region was announced by Foreign Minister Shimon Peres on Jan. 13, 1993 at the ceremony for the signing of the Chemical Weapons Convention, which prohibits the production, stockpiling and use of all chemical weapons.

${ }^{16}$ Matti Steinberg, "The PLO and the Mini-settlement," Jerusalem Quarterly 21 (1981): 130-131.

${ }^{17}$ Quoted in, ibid., 130.

${ }^{18}$ Beres, op. cit., 18.

${ }^{19}$ Ian S. Lustick, For the Land and the Lord: Jewish Fundamentalism in Israel (New York: Council on Foreign Relations, Inc., 1988) 182 . 
${ }^{20}$ One scholar estimates that in 1995, even assuming a continuing high Jewish immigration rate from the former Soviet Union, the Arabs (Israeli citizens and residents of the territories) will still constitute approximately 36 percent of the population of the entire area now under Israeli control. See, Patrick Clawson, "The Limited Scope for Economic Cooperation in the Contemporary Levant, " in Steven L. Spiegel, ed., The Arab-Israeli Search for Peace (Boulder: Lynne Rienner Publishers, 1992) 83.

${ }^{21}$ Rabbi Meir Kahane, Thorns in Your Eyes (New York: Drucker Publishing Co., 1980) 51.

${ }^{22}$ Lawrence Krause and Joseph Nye provide the following definition of economic security: The "absence of threat of severe deprivation of economic welfare." See, Lawrence B. Krause and Joseph S. Nye, "Reflections on the Economics and Politics of International Economic Organizations," in C. Fred Bergsten and Lawrence B. Krause, eds., World Politics and International Economics, (Washington, D.C.: The Brookings Institution, 1975) 330 .

${ }^{23}$ For a discussion on the economic costs to Israel and the Palestinians during the first two years of the intifada, see, Aryeh Shalev, The Intifada: Causes and Effects (Jerusalem: Jerusalem Post Press, 1991) 152-156; F. Robert Hunter, The Palestinian Uprising: A War by other Means (Berkeley: University of California Press, 1991) 147-148; Howard Rosen, "Economic Consequences of the Intifada in Israel and the Administered Territories," in Robert 0 . Freedman, ed., The Intifada: Its Impact on Israel, the Arab World and the superpowers (Miami: Florida International University Press, 1991) 374-385.

${ }^{24}$ Shalev, The Intifada, op. cit., 154.

${ }^{25}$ Rosen, op. cit., 379 .

${ }^{26}$ Ibid. , 380.

${ }^{27}$ Shalev, The Intifada, op. cit., 154.

${ }^{28}$ Ibid. , 155.

${ }^{29}$ Hunter, op. cit., 148.

${ }^{30}$ Shalev, The Intifada, op. cit., 155.

${ }^{31}$ Rosen, op. cit., 374-385. 
${ }^{32}$ Economic pressures imposed on the Palestinian population of the West Bank and Gaza by the Israeli military government and its civil Administration included such harsh measures as curfews of varying duration, the forceful collection of taxes and restrictions on outside fund transfers to the territories. For a more detailed description of these tactics, see, Hunter, op. cit., 146-147 and 194-199.

${ }^{33}$ Shalev, The Intifada, op. cit., 152-153.

${ }^{34}$ For this and two other common definitions of economic interdependence, see, Richard Rosecrance and Arthur stein, "Interdependence: Myth or Reality?" World Politics 26 (1973): 2-5. This study assumes a less stringent definition than that provided by Kenneth Waltz, who presumes that interdependence can exist only between "unlike units" of relatively equal capacity (an assertion which Rosecrance and stein refute). To say that the Israeli and Palestinian economies are interdependent may be misleading if one is using the stricter definition in that the relationship between the two is undeniably one-sided.

${ }^{35}$ clawson, op. cit., 85 .

${ }^{36}$ Rosen, op. cit., 373 .

${ }^{37}$ clawson, op. cit., 86 .

${ }^{38}$ Ibid. , 85 .

${ }^{39}$ In 1988, revenue from work in Israel constituted 34 and 70 percent of the gross local product of the West Bank and Gaza, respectively. These percentages have not changed significantly since that year. See, Shalev, The Intifada, op. cit., 150 .

${ }^{40}$ Hunter, op. cit., 51-52.

${ }^{41}$ Ibid. , 52 .

${ }^{42}$ Heller, op. cit., 79.

${ }^{43}$ For an excellent discussion on the advantages and disadvantages of a Middle East common market, see, clawson, op. cit., 92-94. See also, Gideon Fishelson, "Regional Economic Cooperation in the Middle East," in spiegel, ed., op. cit., 103-120. 
${ }^{44}$ Clawson also argues that the Palestinians stand to profit the most from regional economic cooperation because economic unions benefit the weakest partners (the Palestinian economy is clearly the least self-sufficient in the Middle East). See, Clawson, op. cit., 93.

${ }^{45}$ The failure of Israel and the Arab states to implement a formal water-sharing arrangement from the late 1950's until the 1967 war caused considerable intraregional tensions. In 1965-66, Israel attacked syrian work sites in the Golan associated with a water diversion project which was designed to decrease the flow of water from the Jordan River to Israel.

${ }^{46}$ Clawson, op. cit., 87. See also, Jeffrey D. Dillman, "Water Rights in the Occupied Territories," Journal of palestine studies 19.1 (1989): 47.

${ }^{47}$ Dillman, op. cit., 63.

${ }^{48}$ Liat Collins, "Water as the Way to Peace," Jerusalem Post week ending 9 Jan. 1993, international ed.: 8B.

${ }^{49}$ Dillman, op. cit., 47 and 55-57. See also, Gwyn Rowley, "The West Bank: Native Water-Resource Systems and Competition," Political Geography Quarterly 9 (1990): 42-45 and 48-49. Notably, as both Dillman and Rowley point out, only five permits to drill new wells have been granted to Palestinian residents of the territories since 1967. Jewish settlements, by contrast, have little difficulty obtaining licenses to dig new wells.

${ }^{50}$ Rowley, op. cit., 43-45.

${ }^{51}$ For a discussion on prospective joint Arab-Israeli water projects, see, Clawson, op. cit., 86-91 and Fishelson, op. cit., 115-117. 


\section{NON-SETTLEMENT AND THE JORDANIAN OPTION}

With respect to the general consequences of the status quo, the fundamental point to be stressed is that it is incompatible with peace.

$$
\text { --Mark A. Heller }{ }^{1}
$$

In the first half of this study, the objective was to develop a viable conceptual framework for evaluating the alternatives regarding the ultimate disposition of the Israeli-administered West Bank and Gaza Strip. The framework detailed in chapter 3 centers on a comprehensive notion of Israeli-Palestinian common security encompassing military defense, internal (and regional) stability, economic viability and water security, Palestinian political selfdetermination and the preservation of Israel's Jewish and democratic ideals. The second half of this paper will focus on the actual evaluation of various alternative scenarios, beginning in this chapter with: 1) the continuation of the present status quo; and 2) a return to the status quo ante June 5, 1967 . 
NON-SETTLEMENT

Despite the groundbreaking changes anticipated from the September 1993 Gaza-Jericho autonomy accord, one basic fact remains: The Palestinians still will not have control over land, water, the Jewish settlements and external security. These critical areas excluded from Palestinian authority raise the specter of normalization of the status quo--i.e., continued virtual Israeli sovereignty over the territories.

The perpetuation of the status quo in the West Bank and Gaza Strip, under any guise, is fundamentally untenable for both sides of the conflict. With the criteria set forth in Chapter 3 as the basis of evaluation, it can be readily demonstrated that the status quo--what is tantamount to nonsettlement--is incompatible with the notion of IsraeliPalestinian common security.

\section{Military Security $v$. Self-Determination}

When viewed within the narrow confines of Israel's military security alone, some scholars note that the perpetuation of the status quo affords advantages which diminish the incentive of the Israelis to consider seriously other alternatives. Raphael Israeli, for example, contends that "Israel in control of the Territories has enjoyed much more security, both physical and psychological, than ever before...This consideration is particularly decisive for the 
West Bank, which lies immediately east of the [narrow] coastal plain of Israel." 2

Louis René Beres takes this argument one step further by suggesting that a change in the territorial status quo would, in effect, increase the collective incentive of the Arabs to initiate a war against Israel: "Recognizing an improved configuration of forces vis-à-vis Israel [without the West Bank and Gaza], a large number of Arab states would undoubtedly calculate that they now confront a smaller, more beleaguered adversary." ${ }^{3}$ Thus, Beres assumes that even with a resolution of the Palestinian question, Arab hostility toward Israel will not cease.

To be sure, the geostrategic value of the territories as an Israeli security asset is considerable (see chapter 3). The weakness of the above assertions, however, lies in their failure to assess this overall strategic value within a more comprehensive national security context which takes into consideration the existing realities in the territories and the Arab world at large.

Arguments like those of Israeli and Beres which portray the West Bank and, to a lesser extent, the Gaza as indispensable territorial security buffers would sound rather convincing if these lands were unpopulated. But an objective analysis cannot simply detach Israel's geostrategic position from the security risk posed by the 
1.9 million Palestinian Arab inhabitants of the territories, who are now more actively opposed to living under Israeli rule than ever. Simply put, Israel cannot rely on the territories for military security while simultaneously denying political self-determination to a hostile population which is becoming increasingly frustrated and radicalized.

Beres's argument that a change in the territorial status quo increases the risk of another Arab-Israeli war is particularly troublesome. As evidence that "the belligerence of the Arab states has nothing to do with the Palestinians [emphasis added]," he cites the Iraqi scud missile attacks on Israel during the 1991 Persian Gulf War. ${ }^{4}$ The fact is, however, no Arab state, including Egypt, can or will acquiesce to Israel's permanent retention of the entirety of the West Bank and Gaza and the continued repression of Palestinian self-determination. True, Arab belligerence toward the Jewish state does not emanate merely from the Palestinian question, as evidenced by the Arab states' incessantly hostile military and political behavior toward Israel prior to its acquisition of the territories. Nevertheless, a change in the territorial status quo remains the lowest common denominator of the Arab consensus (inasmuch as such a consensus exists).

Israeli control of lands regarded as indisputably Arab serves as a constant ideological-political prod to 
collective Arab action. In effect, it provides the Arab states with a strong inducement to eventually make war against Israel once the military balance vis-à-vis the latter is perceived by them as favorable. Thus, while total or near-total Israeli withdrawal may not be a sufficient condition for a secure Arab-Israeli peace, it is a necessary one. Together, the two major security risks to Israel--one posed by the Arab states collectively, the other by the Palestinian population of the West Bank and Gaza--would seem to indicate that the potential costs of the status quo outweigh the benefits it accords.

\section{Implications of the status Quo for Internal stability}

The intifada has made it quite clear that continued Israeli subjugation of the Palestinians against their will can only serve as a destabilizing influence within the Arab communities of the West Bank and Gaza. Without question, the social and political unrest in the territories will persist (and likely intensify) unless the Palestinians achieve full self-determination on the basis of the territorial imperative discussed in Chapter 3.

What effect does the status quo have on Israeli internal stability? Raphael Israeli argues that in light of the deep divisions within Israeli society over the question of the West Bank and Gaza, it might be "expedient" to maintain the status quo and postpone as long as possible any 
decisions concerning the final disposition of the territories. 5 This position, however, is rather dubious and shortsighted. The point here is that societal cleavages do exist in Israel; thus, internal stability is already precarious. While the maintenance of the status quo may not seriously exacerbate those cleavages over the short run, it clearly does nothing to promote internal cohesion. Moreover, given what are likely to be the increasing military, political, economic and moral costs to Israel of nonsettlement, there are no guarantees that the status quo will not ultimately deepen existing societal divisions.

A related question for Israel is the impact of the status quo on its Jewish and democratic nature. At best, Israel's present no-withdrawal-no-annexation position permits it to avoid indefinitely the fundamental dilemma regarding the sort of state it will ultimately be: Jewish and democratic, democratic and binational, or Jewish and authoritarian? More pessimistically, the status quo, while ostensibly allowing the Israelis to sweep this problem under the rug, will slowly continue to erode Israel's democratic ideals. Irrefutably, a state simply cannot perpetually oppress a significant portion of the population under its control and, at the same time, remain a true democracy. 


\section{Impact on Common Economic/Water Security}

Finally, it is apparent that the status quo is not conducive to either common economic or common water security. The status quo means a continuation of the conflict, which, it has been seen, entails considerable direct and indirect cost for both sides. The most salient of these costs is the enormous diversion of human and material resources away from factors which contribute to economic development and stability. For the Palestinians, the economic status quo is particularly insufferable simply from the point of view that had they been permitted to become economically independent and to trade with Israel under some form of free (rather than forced) economic cooperation, their weak economy would have been comparably much stronger. 6

In terms of the supply of water, the previous chapter pointed out that present circumstances reveal that a deficit already exists in Israel, Jordan and the territories. Only by effecting a change in the status quo--a termination of the Arab-Israeli conflict--will the parties be able to create the sort of cooperative political environment which is required for the equitable allocation of the region's scarce water resources. Such cooperation is also needed to enable the Israelis, Palestinians and Jordanians to work 
together to explore ways to alleviate the area's serious quantitative and qualitative water problems.

\section{A RETURN TO 1967?}

Since the present status quo clearly cannot serve as a basis for the settlement of Israeli-Palestinian conflict, perhaps a solution can be achieved by a return to the presix-Day-war status quo. After all, some would argue, it is precisely Israel's occupation of Arab lands that is the root cause of the overall Arab-Israeli predicament. Remove the primary source of the problem, so the reasoning goes, and a termination of the conflict would be at hand. Unfortunately, this argument not only ignores the present-day reality in the West Bank and Gaza Strip, it also seemingly omits the two-decade history of open Arab hostility toward Israel prior to June 1967.

Nevertheless, a return to the 1967 status quo merits examination. Some Israelis, while not subscribing to the above argument, still favor an Israeli withdrawal to the pre-1967 borders coupled with a takeover of the territories by the "moderate" King Hussein of Jordan. ${ }^{7}$ As late as the mid-1980's, the Israeli Labor party, which regained power in the 1992 national election, openly advocated at least a limited version of this "Jordanian option" (less than full withdrawal, but a relinquishing of all territory evacuated 
to Jordan).$^{8}$ Notably, a return to the former status quo or some other form of the Jordanian option is commonly discussed (usually unfavorably so) in the professional literature on the Arab-Israeli conflict. ${ }^{9}$

How feasible is this alternative when evaluated on the basis of the comprehensive common security framework? In particular, can the Israelis feel reasonably secure within the pre-1967 borders (the 1949 armistice lines)? Would the Palestinians be satisfied if their goal of political selfdetermination were realized by virtue of naturalization, not in Palestine, but in Hashemite Jordan?

\section{Secure Borders}

Earlier it was argued that Israel, in accordance with the principles of common security, cannot achieve military security unilaterally by holding on to all of the West Bank and Gaza strip. It does not necessarily follow, as M.z. Diab suggests, that outright withdrawal to the 1949-1967 borders would enable Israel to enjoy "a true and real sense of security."10 The Israelis point out that any revision of the present borders as part of a political settlement must provide for Israel's security for decades to come. Furthermore, although there exists a gap among the Israelis between the reality of their military strength and the psychology of their vulnerability, the notion of common security does 
require that reasonable perceptions of threat be taken into consideration. The basic question, then, is whether a settlement involving the final disposition of the territories should start from the premise that a major Arab military threat, however improbable at present, will remain a possibility for the foreseeable future.

There are three major reasons, all of them overlooked by Diab, which render this assumption valid. First, the Arab states with which Israel must reach an accommodation, in addition to (and coincidentally with) a narrower IsraeliPalestinian settlement, are all non-democracies. Unlike in Israel, with its safeguarded democratic institutions, there exists in these states no durable, democratic underpinning for the permanent upholding of political agreements entered into with other countries. Without full democratization, any present or future ruling regime in Syria, Jordan or Iraq formally committed to peace with Israel will face the eventuality of being forcefully supplanted by a radicalized (perhaps fundamentalist) opposition group which refuses to be bound by its predecessor's treaties. Such is the nature of the autocratic Arab world.

Second, it is doubtful that these same Arab states can or will reduce one of the principal asymmetries of the conflict unfavorable to Israel. Israel's historic vulnerability to attack by Arab conventional land armies has 
always been a function of asymmetrical force structures. Specifically, whereas Israel possesses a small standing army with large reserve units, its numerous Arab neighbors generally maintain relatively large standing forces with only a limited role for reserves (see Appendix A). ${ }^{11}$ This enormous gap in Arab and Israeli standing forces engenders Israeli threat perceptions and increases the importance of topography and strategic depth for Israel's conventional defense.

To be sure, a future arrangement whereby the more powerful Arab states were to reduce drastically their standing forces would allay Israeli concerns regarding this asymmetry. It is highly unlikely, however, that a Hafez Assad or Saddam Hussein, whose autocratic regimes rely on large standing armies for internal security as well as for other fronts, could convert the bulk of their active-duty forces to reserve units. In other words, this very real potential threat confronting Israel, for which it must compensate by retaining a geographic margin of security in some form, will likely not decrease in the foreseeable future. ${ }^{12}$

Third, it must be remembered that Arab belligerence) toward Israel long preceded the latter's acquisition of the West Bank and Gaza Strip in June 1967. Though the plight of the Palestinians is now being given more than mere lip 
service by most Arab governments, it is only one of several important components of this deep-rooted Arab animosity. Undeniably, manifestations abound of Arab attitudes toward Israel becoming more accepting of the reality of a permanent Jewish state in the region. Even so, popular and influential anti-Israeli elements presently commonplace in the Arab world are certain to persist indefinitely regardless of the amount of territory Israel concedes.

The above considerations notwithstanding, it may appear that Israel's withdrawal from the entire Sinai Peninsula has established a workable precedent for full Israeli withdrawal from the West Bank and Gaza. In several important respects, however, the case of Sinai is not applicable to the west Bank in particular.

In contrast to Sinai, where demilitarized zones keep Egyptian armored concentrations 200 kilometers from the Israeli border, the much narrower West Bank (maximum width of $57 \mathrm{~km}$.) directly overlooks Israel's densely-populated coastal plain. Were Jordan to reacquire the West Bank, it would have to agree to its demilitarization. However, because of its much smaller size and over-concentrated Arab population centers, a demilitarized West Bank could be violated much more rapidly and/or clandestinely than the regime in sinai. This would be particularly true with the strategic support of a militarily rehabilitated Iraq. ${ }^{13}$ 
Moreover, whereas Israel's possession of the vast sinai Peninsula badly overextended its defensive front lines, the Jordan River (the eastern border of the West Bank) constitutes a much shorter, more natural and more easily defensible frontier than the 1949 armistice boundary.

A final point worth noting is that if history provides any indication, the inclination of an insecure Israeli state reduced to its pre-1967 borders would be to act preemptively (and disproportionately) against the Jordanians and Palestinians at the slightest perceived provocation. One consequence of a total Israeli withdrawal, therefore, would be to increase indirectly Jordanian and Palestinian insecurity as well. (The underlying premise of common security, it must be remembered, is that one side cannot feel secure if the other side feels threatened.)

It is the conclusion of this study that from the standpoint of Israel's military security, a withdrawal to the pre-June-1967 borders must be predicated on the maintenance of a substantial Israeli extraterritorial military presence in the strategic parts of the West Bank (if not also Gaza). Such a scenario, which assumes the acquiescence of the Jordanians and Palestinians (by no means certain), clearly does not constitute an outright return to the status quo ante. (Extraterritorial security arrangements in the West Bank and Gaza will be examined in 
the context of other, more feasible alternatives in Chapters 6 and 7. )

Self-Determination Through Jordanian Citizenship?

Alongside Israel's physical (and psychological) security within the pre-1967 borders is the other key issue concerning the Jordanian option: the juxtaposition of Palestinian political self-determination with Jordanian sovereignty over the West Bank and Gaza Strip. ${ }^{14}$ An Israeli-Palestinian common security framework, it has been seen, requires the fulfillment of self-determination for the 1.9 million Palestinian inhabitants of the territories. Could this requisite for a secure peace be realized were Israel to hand over the territories to Jordan? or would such a scenario be untenable for the Palestinians in that it would ultimately undermine the very essence of their national existence?

On the surface, it seems quite feasible that Palestinian political expression could flourish in the Jordanian state, whose population is over fifty percent Palestinian to begin with. ${ }^{15}$ This is the presupposition often articulated by former Israeli defense minister and long-time Likud Knesset member Ariel Sharon, who also notes that all of the Palestinian residents of the West Bank have retained their Jordanian citizenship. ${ }^{16}$ This premise, however, is at best simplistic. It ignores a multitude of 
factors which clearly militate against the potentiality of Palestinian political self-determination by virtue of Jordanian citizenship.

For one thing, the Palestinian inhabitants of the West Bank (to say nothing of those living in Gaza) have never considered themselves as Jordanians. Arthur Day notes that even when Jordan ruled the West Bank, "the homogenizing process at work between Palestinians and East Bankers in East Bank Jordan between 1948 and 1967 had little effect on Palestinians in the West Bank... If anything, the latter [grew] increasingly disenchanted with Jordan."17 It is inconceivable, especially after the expulsion of the PLO from Jordan during the 1970 Jordanian-Palestinian civil war ("Black September"), that the Palestinians in the West Bank would once again submit to Hashemite domination.

Even more importantly, the PLO has built up so much vested interest--political, ideological and economic--that it would make little sense for it to permit its own absorption into an expanded Jordanian state. Indeed, over the last two decades, the notion of a separate Palestinian identity and political entity has become thoroughly ingrained not only in the Arab world but in the international community as well.

The PLo's first major political victory came in 1974 in the form of formal Arab recognition of the Palestinians' 
right to self-determination. At the october Arab summit in Rabat, the Arab states (including Jordan) officially and unanimously conferred upon the organization the status of "sole legitimate representative of the Palestinian people." one month later, the U.N. General Assembly passed Resolution 3237, formally granting the PLO observer capacity in that body. By the beginning of the 1980's, the PLO had established political relations with over eighty states, including the Soviet Union, the Warsaw Pact states, most of the Third World and several Western European countries. ${ }^{18}$ More recently (November 1988), the Palestine National Council, the PLO parliament-in-exile, unilaterally declared the creation of an independent palestinian state in the territory which had been allotted to Arab Palestine by the 1947 U.N. partition resolution. The Arab states were unanimous in according the "new state" official recognition. Since the onset of the intifada, opinion polls taken among the Arab residents of the West Bank and Gaza have consistently demonstrated their overwhelming support of the PLO--not King Hussein--as their representative. ${ }^{19}$ This reality prompted Hussein to sever all administrative and legal ties between Jordan and the West Bank in July 1988. The king, moreover, has himself declared that were he to negotiate for the return of territory, he would promptly facilitate a Palestinian takeover of that territory within 
the context of a Jordanian-Palestinian federal or confederal arrangement. 20

Officially, it has been a joint Jordanian-Palestinian delegation negotiating with Israel in the ongoing ArabIsraeli bilateral peace talks in washington. From the beginning, however, the Palestinian members of the negotiating team have successfully maintained their total political independence. There are completely separate Israeli-Jordanian and Israeli-Palestinian negotiating agendas and negotiating tracks. Moreover, in clear recognition of the independent-mindedness of the Palestinian people, the Israeli government under Yitzhak Rabin opened a secret dialogue with the PLO in early 1993 without even the knowledge of the Arab states, including Jordan.

Clearly, self-determination, from the Palestinian point of view, means the establishment of a sovereign Palestinian political entity in the West Bank and Gaza. The Palestinians, who for so long have suffered in order to attain their ultimate goal of political independence, are not about to acquiesce to the takeover of the territories by Jordan or anyone else. After all the years of internal turmoil, insurrection and sacrifice, they have come too far politically to revert back to the unsatisfactory status quo of 1967 . 
Implications for Internal stability

For there to be lasting internal stability on both sides, a deficient final political settlement must not be imposed on either party from the "outside." Were Israel, Jordan and the U.S. to conspire in reaching a permanent agreement at the expense of Palestinian prospects for political independence--in clear breach of the principles of common security--the intifada would not cease. Rather, resistance in the territories would simply be redirected against what would surely be considered a Hashemite occupation of Palestinian lands (assuming such an agreement could even progress to the implementation stage in the first place). Not only would Jordan's internal order then be threatened, but, in addition, Israel itself would have to contend with a significantly destabilizing situation just beyond its borders.

If King Hussein's pronouncements are to be believed (see above), they would appear to signal his full understanding of the security risks posed by this Jordanian option. These same risks cannot be ignored by the Israelis, who have a strong stake in the long-term stability of their moderate neighbor to the east.

Nor is a return to the 1967 status quo likely to be favorable for the preservation of Israel's internal stability, which is already somewhat fragile. To be sure, 
the Israelis could effectively resolve the fundamental dilemma concerning the ultimate nature of their state by ridding themselves of the burden represented by 1.9 million Palestinian Arabs in the territories. A return to the circumstances of 1967, however, would entail a full withdrawal from the West Bank and Gaza coupled with a dismantling of all of the Jewish settlements in these territories. These are concessions which the vast majority of Israelis would view as totally unacceptable security risks. ${ }^{21}$ Any government of Israel which would attempt to force such concessions on the public would in all probability face widespread opposition and internal disorder of crisis proportions (including armed resistance by thousands of Jewish settlers in the territories). ${ }^{22}$

\section{Impact on Common Economic/Water Security}

In Chapter 3 it was argued that with the current global trend toward the formation of common economic markets, it would seem that the region's only chance of competing successfully in international markets is by way of advanced economic cooperation. It was further noted that advanced cooperation would be required to enable the Arabs and Israelis to share equitably the region's scarce water resources. Full-scale bilateral and multilateral economic links of this kind clearly do not occur in a vacuum. 
Rather, they necessitate a stable, amicable and cooperative political environment (although economic cooperation, in turn, can contribute to closer political ties between countries). Needless to say, a return to the 1967 status quo, with its likely perpetuation of insecurity and disruption of internal stability on both sides, would be incompatible with the creation of such a political atmosphere between the parties.

Neither the present status quo (Israeli retention of the entire West Bank and Gaza) nor the former status quo (the so-called Jordanian option) are viable alternatives for the final disposition of the Israeli-administered territories. Chapter 5 will now examine what many Palestinians feel is the de facto present status quo: Israeli annexation of the territories. 
CHAPTER IV NOTES

${ }^{1}$ Mark A. Heller, A Palestinian State: The Implications for Israel (Cambridge: Harvard University Press, 1983) 22.

${ }^{2}$ Raphael Israeli, Palestinians Between Israel and Jordan: Squaring the Triangle (New York: Praeger Publishers, 1991) 18 .

${ }^{3}$ Louis René Beres, "Israeli Security in a Changing World," Strategic Review 18.4 (1990): 17.

"Ibid. Beres fails to note that Iraq's scud attacks on Israel were as much a tactical attempt to draw Israel into the war as they were a reflection of Saddam Hussein's open enmity for the Jewish state. The Iraqis clearly had hoped that by forcing Israel to retaliate for the missile attacks, they could compel the saudis and syrians to break away from the anti-Iraq coalition lest they would be perceived by their Arab brethren as fighting on the same side as the Israelis.

${ }^{5}$ Israeli, op. cit., 18.

${ }^{6}$ Gideon Fishelson, "Regional Economic Cooperation in the Middle East," in Steven L. Spiegel, ed., The ArabIsraeli Search for Peace (Boulder: Lynne Rienner Publishers, 1992) 112 .

7Israeli, op. cit., 88 .

${ }^{8}$ F. Robert Hunter, The Palestinian Uprising: A War by other Means (Berkeley: University of California Press, 1991) 164 .

'See, for example, Heller, op. cit., 49-54; Israeli, op. cit., 87-106; Adam Garfinkle, Israel and Jordan in the Shadow of War (New York: St. Martin's Press, 1992) 111-112, 149-156 and 158; Harold H. Saunders, The other Walls: The Politics of the Arab-Israeli Peace Process (Washington, D.C.: American Enterprise Institute for Public Policy Research, 1985) 73-75.

${ }^{10}$ M.Z. Diab, "A Proposed Security Regime for an ArabIsraeli settlement," in Spiegel, ed., op. cit., 163. 
${ }^{11}$ For an excellent discussion on this point, see, Nadav Safran, Israel: The Embattled Ally, 2nd ed. (Cambridge: Belknap/Harvard University Press, 1981) 228-239; Dore Gold, "Great Expectations," Jerusalem Post week ending 8 Feb. 1992, international ed.: 9. While this quantitative gap favorable to the Arabs has widened in recent years, evidence now indicates that the qualitative gap in Arab and Israeli major weapon systems is narrowing rapidly, likewise to Israel's disadvantage. See, for example, Robert E. Harkavy, "After the Gulf war: The Future of Israeli Nuclear Strategy," Washington Quarterly 14.3 (1991): 162-167.

${ }^{12}$ Gold, op. cit., 12 .

${ }^{13}$ Ibid. Gold also provides a convincing argument for the inevitability of the Iraqi military's full rehabilitation. See, same source, p. 9.

${ }^{14}$ It is acknowledged here that a scenario entailing Jordanian sovereignty over Gaza would constitute a modification of the status quo ante of 1967 in that it was Egypt, not Jordan, which controlled that territory from 1949-1967.

${ }^{15}$ For estimates of the percentage of Jordan's population made up by Palestinians, see, Arthur R. Day, East Bank/West Bank: Jordan and the Prospects for Peace (New York: Council on Foreign Relations, Inc., 1986) 57; Daniel Pipes and Adam Garfinkle, "Is Jordan Palestine?" Commentary $86.4(1988): 39$.

${ }^{16}$ Ariel Sharon, Warrior (New York: Simon and Schuster, 1989) 551-554.

${ }^{17}$ Day, op. cit., 60.

${ }^{18}$ Shaul Mishal, The PLO Under Arafat: Between Gun and olive Branch (New Haven: Yale University Press, 1986) 19.

${ }^{19}$ Hunter, op. cit., 151; Israeli, op. cit., 99.

${ }^{20}$ Saunders, op. cit., 75.

${ }^{21}$ Israeli, op. cit., 100. A May 1993 Gallup poll indicates that 59 percent of the Israeli population oppose withdrawal to the pre-1967 borders, even "with slight modifications;" 69 percent believe that the Jewish settlements in the territories must remain under permanent Israeli sovereignty. See, "A Startling Poll," Jerusalem post week ending 22 May 1993, international ed.: 8. 
${ }^{22}$ As was noted in Chapter 3, Ian Lustick concludes that such profound internal disorder would be probable even were Israel to make only partial territorial concessions. See, Ian S. Lustick, For the Land and the Lord: Jewish Fundamentalism in Israel (New York: Council on Foreign Relations, Inc., 1988) 182 . 


\section{CHAPTER V}

\section{UNILATERAL ISRAELI ANNEXATION}

The majority of the public is for [keeping] Eretz Yisrael but opposes the annexation of 1.5 million Palestinian Arabs; and it is no longer possible to think that you can annex the territory and at the same time deny Israeli citizenship to its inhabitants. And do not live with the illusion that you can expel them.

--Rabbi Yoel Ben-Nun, Gush Emunim (1988) ${ }^{1}$

If a comprehensive notion of common security is to serve as the basis of an Israeli-Palestinian political settlement, then clearly the Israelis cannot continue to dominate the Palestinians against their will. Nor can the Palestinians insist that the Israelis withdraw to the precarious pre-1967 borders without permitting them (or perhaps a neutral third party) to maintain a substantial military presence in the territory evacuated.

A fundamental question which arises is whether Israel can retain its present frontiers without, at the same time, subjugating the Palestinians residing within these expanded borders. That is, could not Israel annex the West Bank and Gaza strip and either grant the Arab inhabitants full civil and political rights, actively encourage or compel the bulk of them to emigrate, or at least permit them to run their 
day-to-day affairs without undue interference? This chapter examines the feasibility of Israeli annexation of the territories. Three scenarios, each unique in terms of its ramifications for the 1.9 million Palestinian Arabs of the territories, will be analyzed: 1) Israeli citizenship; 2) population transfer; and 3) autonomy.

\section{POLITICAL EQUALITY WITHIN A GREATER ISRAEL?}

The notion of Israel annexing the west Bank and Gaza and simultaneously granting the Arab inhabitants of these territories full civil and political rights has been around ever since the end of the 1967 Six-Day War. One of the original proponents of this idea was Eliezer Livneh, a founding father of the pro-annexationist Land of Israel Movement. In his 1972 book, Israel and the Crisis of Western Civilization, ${ }^{2}$ Livneh presents an optimistic outlook for future Arab-Jewish relations in a Greater Eretz Yisrael. According to Livneh, the provisions in Israel's Declaration of Independence ensuring full political rights for the Arabs of pre-1967 Israel (Israel has no constitution) should be equally applicable to the Arab residents of the territories once these areas were formally annexed to the Jewish state. Thus, the Palestinians, as equal citizens of a Greater Israel, would possess the right to vote in national and municipal elections and the right to hold public office. 
Those who wished to maintain dual citizenship in Israel and one of the neighboring Arab states would be allowed to do so. 3

In the conclusion of his chapter on Arab-Jewish relations, Livneh clearly envisages a binational Israeli state:

The historical processes of Shivat Tzion [the return to $\mathrm{Zion}$ ] make a favorable policy towards the Arabs necessary and possible. The zionist thinkers knew that the Jews were not returning to an unpopulated country. The Arabs are part of the Israeli state and belong to its nature, including its cultural nature. Israel without the Arabs would be missing an important component. ${ }^{4}$

Among the Palestinians, Sari Nusseibeh first proposed the idea of Israeli citizenship for the Arab residents of the West Bank and Gaza in the summer of 1987. Nusseibeh reasoned that the Palestinians, because of their high birth rate, would constitute a majority of Greater Israel's population shortly after the turn of the century. With an Arab majority in the Knesset, they could work within Israel's own political system to undo the Jewish and Zionist foundation of the state, transforming Israel into an Arab Palestine. 5

At first glance, the establishment of a binational Arab-Jewish state (whether it is called Israel or Palestine) would seem to reflect the very essence of the concept of 
common security. With the appendage of the West Bank and Gaza to Israel proper, the Israelis would have their required secure and recognized borders (this assumes, of course, that the Arab states would formally agree to the formation of a binational state once the Palestinians accepted this plan). The Palestinians, as citizens of the new state, would gain true political self-determination on the basis of the territorial imperative (sovereignty in their homeland). Together, the two peoples could build an economically vibrant state in which all resources, including water, were shared equitably. A binational state, therefore, would seem to constitute Israeli-Palestinian coexistence in the purest sense.

still, the case for the incorporation of the Palestinians into a Greater Israel overlooks two critical components of common security. Livneh, for his part, completely disregards the eventuality--indeed, the likelihood--of an Arab majority in an expanded Israeli state. As Chapter 3 noted, the Palestinian Arab population growth rate strongly indicates that Arab citizens of a Greater Israel would outnumber Israeli Jews within a halfcentury. Could an Israel with an ever-increasing Arab majority remain a Jewish state? The answer is clearly no.

This demographic threat is precisely the reason why Nusseibeh and other moderate Palestinians have, ironically, 
proposed the same "solution" as that suggested by Israeli rightists like Livneh. If the Palestinians were willing to be patient, they could eventually achieve their dream of an independent PLO-led state from the Jordan River to the Mediterranean at the total expense of Jewish nationalism. It is the potential demise of zionism, however, which is contrary to the notion of Israeli-Palestinian common security discussed in Chapter 3.

since he initially proposed the idea of a binational Israeli state, Nusseibeh has reevaluated the feasibility of this alternative and now openly favors a two-state solution to the conflict. ${ }^{6}$ Indeed, the suggestion that the palestinians be incorporated into a Greater Israel met with immediate disapproval throughout the territories. As Emile Sahliyeh notes, the high degree of emotionalism associated with the Palestinian question and the deep-rooted enmity between the parties inherently limit the appeal of a binational state among the vast majority of palestinians (if not also the Israelis). ${ }^{7}$

Furthermore, the Palestinians want to be the ruling majority in a sovereign political entity now, not at some indeterminate, distant point in the future. projections regarding the timing of the Arabs becoming a majority in a Greater Israel are based on current demographic trends. Unforeseen events--such as a resurgence of the high level of 
Jewish immigration to Israel from the former Soviet Union experienced at the beginning of the 1990's--could significantly delay the attainment of an Arab majority still further. Simply put, a settlement based on the granting of Israeli citizenship to the Palestinians would unquestionably trigger widespread, vehement Arab opposition, thus precluding the realization of a stable peace.

\section{POPULATION TRANSFER}

The notion of "transferring" the Arab inhabitants of the West Bank and Gaza to another Arab country, while actively advocated by only a fringe element in Israeli society, has gained legitimacy among some mainstream sectors of the population. ${ }^{8}$ The intifada, the escalating tension between Jewish settlers and Palestinians in the territories and the increasing Palestinization of the Israeli Arabs have contributed to the creation of an emotion-laden atmosphere in which drastic solutions to the conflict are now seen as acceptable by some Israelis. In the 1992 national election, for example, Moledet (Homeland), a radical right-wing party which has made the transfer concept the principal plank in its platform, won three of the 120 seats in the knesset. In addition, Rafael Eitan's nationalist Tzomet (Crossroads) party, which supports the eventual transfer of the Arab population of the refugee camps in the territories, sent 
eight representatives to the parliament (an increase of six seats from the 1988 election).

Transfer as a general concept is most prominently associated with Joseph Schechtman, one of the greatest authorities on Asian and European refugees. Writing in the 1960's, Schechtman favored the transfer of ethnic groups as a solution to inordinately complex territorial/nationality conflicts which had proven to be insoluble in any other way. 9 Compulsory transfer, according to schechtman, must be seen not as a retaliatory measure, but in essence as a preventive action necessitated when the integrity, security and stability of a state are endangered by a threatening minority:

If large sections of an ethnic minority within a state consistently negate their very allegiance to the state; repeatedly create friction and conflicts... nourish irredentist tendencies and thus jeopardize the integrity of the state; and if all attempts at reconciling this minority and integrating it into the framework of common statehood fail, then--and only then--recourse may be taken to the grim necessity of population transfer. ${ }^{10}$

Transfer, of course, is not without precedent. In postwar Europe, for example, eight transfers were carried out between 1945 and 1955. Of these, three were bilateral exchanges of population (Polish-Soviet, Soviet-Czechoslovak and Hungarian-Czechoslovak); five involved the unilateral removal of ethnic Germans from Czechoslovakia, Romania, 
Yugoslavia, Hungary and Poland. ${ }^{11}$ In the Polish case, hundreds of thousands of Germans were expelled from territories which Poland had "recovered" as a result of the Allied victory over the Nazis. ${ }^{12}$ clearly, ethnic sifting was thought to be a radical, yet necessary solution to many of the territorial and minority-related problems in various European danger zones.

This sort of thinking was also in evidence before the second world war and in specific regard to the Arab-Israeli conflict. In 1937, the British Peel Commission recommended the partition of Mandatory Palestine into two states--one Jewish, the other Arab. Acknowledging the infeasibility of coexistence among bitter enemies with separate aspirations regarding the same land, the commission proposed the transfer of some 225,000 Arabs residing in the projected Jewish state in order to facilitate this scheme. ${ }^{13}$

Why not consider the massive Jewish exodus from Arab countries to Israel in the 1950's and 1960's (some 600,000 Jews) the first step of a "population exchange," to be followed by a Palestinian exodus from the Israeliadministered territories to Arab lands? In this way, Israel could seemingly retain the strategically important West Bank and Gaza and, simultaneously, eliminate the Arab demographic threat to its Jewish nature. Or, as the leader of the Moledet party, Rehavam Ze'evi, is fond of saying, "Anachnukan, 
hem sham, veshalom al Yisrael!" ("We are here, they are there, and peace for Israel!"). ${ }^{14}$

Aside from the salient moral considerations concerning the notion of transfer, no other scenario for the disposition of the territories is as unrealistic and contrary to the principles of common security. For one thing, whereas Schechtman notes that a transfer operation must be compulsory (as opposed to voluntary) to be efficacious, he acknowledges that international jurists generally regard unconditional compulsory transfer to be inconsistent with democratic concepts of human rights. He therefore concludes that, "For persons who should choose to remain [as individual citizens] in the country of their residence, there would be no question of forcible transfer [emphasis added ] . "15

Schechtman apparently believes that as presumably loyal citizens, those individuals opting to be exempted from transfer could in no way endanger the integrity of the state in which they resided (or perhaps there would be so many legal and/or bureaucratic barriers to appealing the transfer successfully that few would apply for exemption). As was argued above, this is clearly not the case for Palestinians who would choose to become citizens of a Greater Israel. For it is precisely as law-abiding citizens that the Palestinians, as the future majority, could eventually 
undermine the Jewish and Zionist nature of the Israeli state.

In order to eliminate this Arab demographic threat, therefore, a population transfer conducted by the Israelis would have to be non-voluntary and virtually unappealable. Yet, in terms of physical security, internal stability and economic prosperity, Israeli annexation of the territories coupled with a truly compulsory transfer would be profoundly antithetical to the interests of both sides.

Assuming that such an operation could be carried out, what sort of physical (and psychological) security and communal stability could be enjoyed by the hundreds of thousands of Palestinians who would be uprooted from their homeland? How could Palestinian families survive over the long run the loss of their homes, businesses and property, even assuming Israeli compensation? Realistically, no Arab state would be able (economically) or willing (politically) to absorb a sufficient number of the expelled Palestinian population to ease its plight. By and large, the transferees would thus end up unwanted, homeless and jobless refugees, becoming further embittered and radicalized.

Likewise, the inevitable costs to the Israelis of such a course of action would be staggering. A one-sided, compulsory transfer of the Palestinian inhabitants of the territories would be an overt and excessive violation of the 
common security principle proscribing unilateral security "gains" at the expense of the adversary. In addition to the obvious moral price, the attempted implementation of a transfer would exacerbate the Arabs' collective hostility toward--and suspicion and fear of--Israel, thus further intensifying the Arab-Israeli conflict. Specifically, Israel's Arab neighbors, which would undoubtedly regard such an act as a casus belli, would have no choice but to go to war with Israel. Egypt, the only Arab country to have formal diplomatic relations with the Jewish state, would be under immense pressure from within and without to abrogate the Israeli-Egyptian peace treaty and join in the military effort against Israel.

A population transfer, moreover, would deeply alienate the overwhelming majority of the international community (including the United States), most of Diaspora Jewry and many Israelis themselves who would no longer feel that they were living in a democratic state. Not only would the U.S. and other western countries terminate all foreign economic and military aid to Israel, but severe U.N.-imposed economic and political sanctions against the latter would likely be forthcoming. In such difficult and destabilizing circumstances, the Israelis would lack physical, psychological and economic security, and their internal cohesion would be seriously undermined. One can only reasonably conclude, 
therefore, that a compulsory population transfer of the west Bank and Gazan Arabs would have catastrophic consequences for the Israelis themselves as well as the transferees.

A final point which needs to be stressed relates back to the concept of common security as an underlying philosophy of conflict-resolution. This study has focused on the theorized capacity and suitability of the common security framework to resolve a seemingly intractable conflict in which each party: 1) has legitimate, security-related claims that are inextricably bound up with the vital interests of the other side; and 2) poses a credible threat to the security of the other side. It is only through mutual compromise and cooperation that the parties can extricate themselves from their common predicament.

Population transfer, by contrast, constitutes a unilateral "solution" to what is presumed to be a strictly onedimensional conflict in which the security of one party (i.e., a state) is endangered by another (i.e., an ethnic minority residing within territory controlled by that state). The notion of transferring the Arabs from the territories presumes--incorrectly--that the sole cause of the problem is the general Arab threat to Israel's security. It thus demonstrates absolute disregard for the other half of the equation--Israel as a threat to Palestinian national survival. If transfer were truly a viable option for the 
ultimate disposition of the West Bank and Gaza, there would seem to be an even stronger justification for transferring the minority of Jewish settlers out of these territories and making them homogeneously Arab.

\section{AUTONOMY}

The third version of Israeli annexation would take place in conjunction with autonomy for the Palestinians. Historically, autonomous arrangements have been conceived of to appease (and control) members of a large ethnic group who are citizens of the state in which they reside, such as the Tamils and Sikhs (India), the Basques and Catalonians (Spain), the Eritreans (Ethiopia) and the Kurds (Iraq). ${ }^{16}$ Most recently, the division of Bosnia-Herzegovina into ten autonomous enclaves was the basis of the initial U.N.sponsored peace plan to end the bloody civil war among that state's Serbian, Croatian and Muslim populations.

Nevertheless, as was argued above, the notion of Israeli citizenship for the Palestinian residents of a Greater Israel is not a viable option, even were it to be connected with a liberal autonomous arrangement for the West Bank and Gazan Arabs. Any potential Israeli-Palestinian autonomy scheme, therefore, could not be predicated on true Palestinian incorporation into Israel. 
Autonomy is a rather nebulous concept. The 1978 Camp David Accords signed by Israeli Prime Minister Menachem Begin and Egyptian President Anwar Sadat called for the provision of "full autonomy to the [Palestinian] inhabitants" of the West Bank and Gaza under a "selfgoverning authority."17 However, no unambiguous definition of "full autonomy" is provided in the text of the accords. Consequently, the Israelis and Egyptians held vastly different views concerning the content of the proposed autonomy, which never converged in the subsequent autonomy negotiations. ${ }^{18}$

One distinction often made in the literature on autonomy is personal, or administrative, autonomy versus territorial autonomy. ${ }^{19}$ Begin's narrow interpretation of autonomy was of the personal variety. His plan envisioned a locally elected Palestinian administration and judiciary which were to exercise personal jurisdiction in the areas of education, religion, industry, commerce, agriculture, tourism, housing, welfare, refugee rehabilitation, health, and local law enforcement. In addition, the Palestinians were to choose between Israeli, Jordanian or Egyptian citizenship. Excluded from this arrangement was even limited Palestinian sovereignty over any West Bank or Gazan territory; thus, matters pertaining to foreign policy, 
military security, internal order and land use were to be left solely to the Israelis. ${ }^{20}$

Ariel Sharon, a long-time proponent of Begin's notion of autonomy, favors the creation of Palestinian autonomous regions with no territorial contiguity. ${ }^{21}$ According to Sharon's plan, the widely scattered Jewish-populated areas of the West Bank and Gaza would be annexed to Israel. The Arab inhabitants of the non-annexed portions of the territories would be granted personal autonomy (here, Sharon is not clear regarding who would have ultimate sovereign control over these non-annexed areas). The minority of West Bank and Gazan Arabs coming under Israeli sovereignty, like the Palestinians of the autonomous enclaves, would continue to be full-fledged citizens of Jordan. They could therefore vote in Jordanian parliamentary elections and hold office in the Jordanian government. ${ }^{22}$

This scenario of de facto Israeli annexation of all or nearly all of the West Bank and Gaza is compatible with the fallacious notion held by Sharon, Rafael Israeli and other right-wing Israelis that Jordan is the Palestinian state. ${ }^{23}$ In fact, historically, geographically, culturally and politically, Jordan is not Palestine. ${ }^{24}$ Moreover, Sharon's and Israeli's suggestion that Arab Palestine be based on the East Bank of the Jordan is, in effect, tantamount to the Jordanian option, only without any Arab territorial 
sovereignty in the West Bank and Gaza. It has already been demonstrated that even the non-watered-down version of the Jordanian option is contrary to the concept of common security, particularly regarding the requirement of Palestinian political self-determination (see Chapter 4).

\section{Territorial Autonomy}

An ostensibly more promising alternative to Palestinian administrative autonomy linked to Jordanian citizenship is the notion of Palestinian territorial autonomy within a Greater Israel. According to the latter scheme, the Palestinians, though non-citizens, would gain those powers which Hurst Hannum identifies with full territorial autonomy: 1) a locally elected legislative body with a degree of independent authority; 2) a locally elected or appointed chief executive; 3) an independent local judiciary with full responsibility for interpreting local laws; and 4) a liberal power-sharing arrangement between the autonomous and central governments which would deal with matters of joint concern, such as public order, the exploitation of natural resources, trade, and transportation and communications facilities. (The autonomous entity would have virtually full competence to deal with a wide range of other matters, including education, religion, industry, agriculture, land use and planning, housing and welfare.) $)^{25}$ 
Israeli annexation of the territories in conjunction with full Palestinian territorial autonomy in the west Bank and Gaza (excluding certain Jewish-populated areas in the vicinity of Jerusalem) may seem to meet most of the requirements for an Israeli-Palestinian peace based on common security. Israel would retain the strategic depth afforded by the appendage of the West Bank, minus the Arab demographic threat to its Jewish character. At the same time, the Palestinians would enjoy a high degree of independent political expression in what they consider to be a part of their historic homeland. In other words, the same territory could potentially satisfy both sides' physical and psychological security needs and, in addition, the Palestinians' collective identity needs. Moreover, powersharing in areas of common concern should facilitate Israeli-Palestinian economic cooperation, including the equitable allocation of scarce water resources.

A scenario involving Palestinian territorial autonomy, then, contains some positive features. Nevertheless, there are two major problems with this alternative. One problem concerns Israeli security within the overall context of the wider Arab-Israeli conflict; the other pertains to the requisite elements of Palestinian self-determination.

The above scenario assumes that Israel's Arab neighbors would acquiesce to Israel's annexation of the West Bank 
(including East Jerusalem) and Gaza. Yet, even were the Palestinians to accept territorial autonomy as a final solution (itself a dubious proposition for reasons to be discussed shortly), it is almost inconceivable that the Arab states would reconcile themselves to permanent Jewish rule over what they regard as indisputably Arab lands. Retention of the territories by Israel serves as a perpetual reminder of the humiliating collective Arab failure of June $1967 .^{26}$ Israeli annexation of these lands would not only fail to remove a significant ideological-political stimulus underlying Arab belligerency toward the Jewish state, it would undoubtedly exacerbate it. In this sense, Israel, even with expanded borders, would continue to face a very real collective Arab threat to its physical security.

\section{Autonomy v. Self-Determination}

To understand the other aspect by virtue of which the territorial autonomy alternative breaks down, it is important to answer the question: Can political selfdetermination be achieved through full autonomy? That is, can Palestinian territorial autonomy be equated with Palestinian political independence?

The meaning and content of the principle of selfdetermination by "national" groups are somewhat vague and imprecise. Nevertheless, the 1960 Declaration on the Granting of Independence to Colonial Countries and Peoples 
(U.N. General Assembly Resolution 1514), the 1970

Declaration on Friendly Relations (U.N.G.A. Resolution 2625) and two international covenants on human rights all define the right to self-determination in a similar manner. ${ }^{27}$ Specifically, each refers to it as the right of all peoples to determine, without external interference, their "political status" and to pursue freely their "economic, social and cultural development." 28 Furthermore, the Declaration on Friendly Relations states:

The establishment of a sovereign and independent state, the free association or integration with an independent state or the emergence into any other political status freely determined by a people constitute modes of implementing the right of self-determination by that people.

To be sure, the debate concerning whether the right to self-determination is jus cogens (widely acknowledged law), and, if so, whether it is applicable to the Palestinian case in particular, will remain contentious (and irresolvable insofar as this paper is concerned). The point here, however, is that it is clearly the above conception of selfdetermination whose fulfillment the Palestinians require to end their struggle against the Israelis. The notion of common security does not make judgments on the moral or legal validity of this Palestinian demand. Rather, it requires only that this lowest common denominator of the 
Palestinian consensus be implemented without jeopardizing Israel's vital security interests.

Hurst Hannum notes that territorial autonomy is not equivalent to full political self-determination as described above $^{30}$ (though it may be considered a lesser form of selfdetermination if it is the ultimate will of the population in question). He further states that the autonomous entity "should not expect to be immune from the influence of [the central government]" and that its powers must be exercised only "within the overall framework of the fundamental norms of the state [emphasis added]." ${ }^{31}$ Notably, all matters relating to military security and foreign policy are to remain strictly under the control of the central government.

From the Palestinian perspective, then, territorial autonomy is a smokescreen for continued domination by Israel and the perpetual subordination of Palestinian Arab interests to what are often antithetical Jewish/Zionist objectives. Such a scenario would seem to be inherently at odds with the basic precepts of Israeli-Palestinian common security. Another alternative, therefore, must be found. 
CHAPTER V NOTES

'Quoted in, Ehud Sprinzak, The Ascendance of Israel's Radical Right (New York: Oxford University Press, 1991) 163.

${ }^{2}$ Eliezer Livneh, Israel and the Crisis of Western Civilization (Tel Aviv: Schoken Publishing House, 1972).

${ }^{3}$ Ibid. , 117-118.

${ }^{4}$ Ibid., 118 .

${ }^{5}$ Emile Sahliyeh, In Search of Leadership: West Bank Politics Since 1967 (Washington, D.C.: The Brookings Institution, 1988) 173.

${ }^{6}$ Sari Nusseibeh and Mark A. Heller, No Trumpets, No Drums: A Two-state settlement of the Israeli-Palestinian Conflict (New York: Hill and Wang, 1991).

${ }^{7}$ Sahliyeh, op. cit., 173-174.

${ }^{8}$ Sprinzak, op. cit., 172-176. The concept of transfer is often spoken of in terms of an "agreed-upon" transfer as opposed to the forced, unilateral expulsion of the Arabs proposed by Rabbi Meir Kahane. For a perspective on the latter, see, Rabbi Meir Kahane, They Must Go (New York: Grosset and Dunlap, 1981).

9 Joseph B. Schechtman, Postwar Population Transfers in Europe: 1945-1955 (Philadelphia: University of Pennsylvania Press, 1962).

${ }^{10}$ Ibid., 364-365. It should be noted that Israel has attempted (without success) to integrate into "common statehood" only those Palestinians residing in East Jerusalem.

${ }^{11}$ Ibid. , 378

${ }^{12}$ For details of the removal of ethnic Germans from the Polish Recovered Territories, see, ibid., 180-212.

${ }^{13}$ Raphael Israeli, Palestinians Between Israel and Jordan: Squaring the Triangle (New York: Praeger Publishers, 1991) 170 . 
${ }^{14}$ Quoted in, Sprinzak, op. cit., 173.

${ }^{15}$ Schechtman, op. cit., 383.

${ }^{16}$ For an excellent discussion on actual or proposed autonomous arrangements for these groups, see, Hurst Hannum, Autonomy, Sovereignty and Self-Determination: The Accommodation of Conflicting Rights (Philadelphia: University of Pennsylvania Press, 1990) 151-202, 263-307 and 337-341.

${ }^{17}$ For the full text of the Camp David Accords, see, William B. Quandt, Camp David: Peacemaking and Politics (Washington, D.C.: The Brookings Institution, 1986) 376-387.

${ }^{18}$ For a discussion on Begin's narrower interpretation of autonomy, see, Israeli, op. cit., 116-118.

${ }^{19}$ For a discussion on the elements of personal and territorial autonomy, see, Hannum, op. cit., 458-468. Note: The autonomy envisioned by the sept. 1993 Israeli-PLO agreement, which would give the Palestinians of Gaza and Jericho authority in the areas of education, health, welfare, economic development, tourism and direct taxation, is of the personal variety.

${ }^{20}$ Israeli, op. cit., 116; see also, Amos Perlmutter, Israel: The Partitioned State (New York: Charles Scribner's Sons, 1985) 289-290.

${ }^{21}$ Ariel Sharon, Warrior (New York: Simon and Schuster, 1989) 551-555. See also, Ariel Sharon, "Autonomy Means Statehood," Jerusalem Post week ending 22 Aug. 1992, international ed.: 7 .

${ }^{22}$ Ibid.

${ }^{23}$ Ibid.; Israeli, op. cit., 177-190.

${ }^{24}$ For a well-reasoned repudiation of the "Jordan is Palestine" claim, see, Daniel Pipes and Adam Garfinkle, "Is Jordan Palestine?" Commentary 86.4 (1988): 35-42. 
${ }^{25}$ For more details, see, Hannum, op. cit., 458-468.

Hannum's notion of territorial autonomy approximates Daniel Elazar's definition of a federacy: An asymmetrical permanent linkage between two self-governing entities with the larger possessing specific powers within the smaller (e.g., those related to military security and foreign policy) and the latter retaining control over certain internal functions. See, Daniel J. Elazar, Two Peoples... One Land: Federal

Solutions for Israel, the Palestinians, and Jordan (Lanham: University Press of America, Inc., 1991) 41, 50-54 and 112114 .

${ }^{26}$ For a comprehensive discussion on the impact of the 1967 defeat on the collective Arab psyche, see, Fouad Ajami, The Arab Predicament: Arab Political Thought and Practice Since 1967 (New York: Cambridge University Press, 1981) 175 .

${ }^{27}$ The two international covenants on human rights are: the International Covenant on Economic, social and Cultural Rights, adopted by the U.N.G.A. in Dec., 1966 and entered into force Jan., 1976; the International Covenant on Civil and Political Rights, adopted by the U.N.G.A. in Dec., 1966 and entered into force March, 1976. See, Hannum, op. cit., 41-42.

$$
\begin{aligned}
& { }^{28} \text { Ibid. , } 27-49 . \\
& { }^{29} \text { Ibid. , } 41 . \\
& { }^{30} \text { Ibid., } 468 . \\
& { }^{31} \text { Ibid. }
\end{aligned}
$$




\section{CHAPTER VI}

THE FEDERAL APPROACH: SELF-RULE AND SHARED RULE

Peace has existed in the Middle East only under conditions when now-conventional notions of sovereignty have been drastically limited and principles of shared power have operated in their place.

$$
\text { --Daniel J. Elazar' }
$$

If neither Israeli withdrawal to the pre-1967 borders nor Israeli annexation of the West Bank and Gaza are feasible alternatives, what other options for a political settlement exist? Perhaps a realistic solution can be found by considering some sort of federal arrangement among the Israelis and Palestinians which combines self-rule and shared rule within the same territory. Indeed, according to the Jerusalem Center for Public Affairs, nearly sixty countries have already applied federal solutions to accommodate ethnic heterogeneity within their boundaries. ${ }^{2}$

Federalism is deemed promising by proponents because it transcends the original European notion of sovereign statehood, which, they argue, is wholly inappropriate for the Middle East with its mosaic of populations. 3 Notably, this inventive alternative, unlike the largely zero-sum options of full Israeli withdrawal or Israeli annexation, 
possesses many features that are predominantly positive-sum in nature.

Various types of federal schemes have been suggested as potential solutions to the Israeli-Palestinian conflict. Ze'ev Schiff and Ehud Ya'ari, for example, propose a confederative framework between Israel, Jordan and a "Palestinian entity to be constituted in the West Bank and Gaza. "4 The confederation would adopt a binding constitution which would obligate the Palestinian entity to remain demilitarized and to refrain from allying itself militarily with any other states. This common constitution could not be amended or abrogated except by unanimous agreement among the three constituent members. The authors, moreover, envisage an Israeli extraterritorial military presence in the Jordan valley and an early-warning station in the West Bank to be operated jointly by Israelis, Palestinians and Jordanians. 5

Similarly, Daniel Elazar, a world-renown champion of federalism, favors "a Palestinian-Jordanian federation in new boundaries that will reflect Israel's security needs, overlaid by a confederation with Israel [emphasis added]."6 The Palestinian-Jordanian federation would consist of two or three constituent states (either Jordan-Palestine or Jordan, the West Bank and Gaza) with one over-arching federal government. The confederation, in essence a permanent 
constitutional union between the latter and Israel, would be responsible for military security in the West Bank and Gaza, allocation of common water resources and economic and fiscal coordination. ${ }^{7}$

Such a confederation-federation combination, Elazar contends, would satisfy the vital interests of all the parties:

The Palestinians would get their state, albeit as a federal state rather than a separately independent one, and also a guaranteed share in the common governance of the Arab [constituent] state. Jordan would continue to have a standing west of the [Jordan] river. Israel would get secure borders, recognition by its Arab neighbors, and a continuing relationship with those parts of the historic Land of Israel not within its full political jurisdiction.

Clearly, Elazar, as well as other proponents of an Israeli-Jordanian-Palestinian confederation, believes that the federal approach offers an equitable solution of the conflict. To be sure, a confederative arrangement would seem to satisfy, at least in part, several of the requirements of common security: the maintenance of the parties' physical security, the achievement of Palestinian self-determination, the preservation of Israel's Jewish and democratic nature and the development of economic and water cooperation. It remains to be seen, however, whether this is the optimal solution. 
IMPACT ON MILITARY SECURITY

Elazar argues that only his confederative option, unlike a "two-state" solution, would provide adequate security to each of the parties, Israel in particular. This argument is largely predicated on the claim that an independent Palestinian Arab state west of the Jordan River would pose an unacceptable level of risk not only to Israel but to Jordan and the Palestinians as well (this claim is challenged in the next chapter). According to Elazar, the establishment of such a state would deprive Israel of "secure" borders and threaten to undermine the Hashemite regime in Jordan, over half of whose population is Palestinian. As a relatively poor state, its creation would also subject the Palestinian Arab community to perpetual instability and internecine warfare. 9

By contrast, a confederation between Jordan/Palestine and Israel, with the latter's borders "adjusted" to provide it with a degree of strategic depth, would ultimately rely on a joint defensive presence to meet the common security needs of the Jewish and Arab inhabitants of the West Bank and Gaza. Israel, moreover, would serve as a guarantor to the Palestinians and Jordanians that each would abide by its federal obligations vis-à-vis the other, including securityrelated agreements. 10 According to Elazar, "The only way 
that a Palestinian link with Jordan would ensure protection for the Palestinian Arabs [from Hashemite subjugation] would be if it also included an Israeli presence." 11 (Schiff and Ya'ari add that only close cooperation between the confederative partners could yield positive results in countering common terrorist threats from extremists. ${ }^{12}$ ) Military security, then, would be achieved in large part by expanding Israel's borders and by giving the three constituent members a common stake in each other's defense.

The creation of a positive-sum system of cross linkages (in this particular context, military linkages) is critical to the establishment and maintenance of peace based on common security. However, the demarcation of boundaries--in this case, the extension of one party's borders at the expense of the other--is contrary to the notion of common security. ${ }^{13}$ Elazar acknowledges this zero-sum nature of border delineation. Indeed, he attempts to circumvent the problem by proposing that each of the constituent members of the confederation would possess secondary territorial rights (to be determined in negotiations between the parties) across its primary borders. ${ }^{14}$

Nevertheless, the border adjustments Elazar suggests--Israeli annexation of "those segments of Judea, Samaria and Gaza needed for security purposes or so intensively settled by Israeli Jews as to be appropriately 
part of the Jewish state" 15 --are glaringly one-sided. It is difficult to accept, therefore, that limited extraterritorial rights could compensate the Palestinians for a formal renunciation of their claims to primary sovereignty over these lands. Here, Elazar's assertion that his confederative scheme would ensure Israel's physical security ceases to be convincing. It rests on the dubious assumption that the Palestinians and Israel's Arab neighbors would acquiesce to the Jewish state's de facto absorption of whatever territory the Israelis deemed necessary for the establishment of defensible borders!

\section{MEANINGFUL SELF-DETERMINATION?}

A confederative arrangement including the Arab residents of the West Bank and Gaza could go a long way in satisfying Palestinian aspirations for political selfdetermination. Both the Palestinian federated state envisioned by Elazar and the Palestinian entity proposed by Schiff and Ya'ari would enjoy a high degree of political independence (from Jordan as well as Israel) and thereby possess substantial self-governing powers. ${ }^{16}$ Thus, for the first time ever, the Palestinians would ultimately achieve a meaningful share in virtually every aspect of their governance. 
This provision of self-rule notwithstanding, does the confederation-federation alternative go far enough in meeting the requirement of Palestinian self-determination? According to one widely accepted definition of selfdetermination, federation with an existing independent state is only one of several legitimate means by which it may be implemented; the establishment of a sovereign independent state is another (see chapter 5, the Declaration on Friendly Relations). This is precisely Elazar's point when he states, "Separate politically sovereign statehood in the Classic European mold is not the only way to secure selfdetermination...The Palestinians will have to achieve selfdetermination through federal arrangements." 17

still, the Palestinians universally demand independent statehood and might not be content with anything less. That is, they will not terminate their struggle against Israel until statehood is realized (see section on Palestinian Dissatisfaction and Internal stability, below). Perhaps the most relevant question here is whether "separate politically sovereign statehood," in some form, could be achieved by the Palestinians without it being inimical to Israel's vital security interests. This question will be examined in detail in the following chapter. 
IMPLICATIONS FOR ISRAEL'S JEWISH AND DEMOCRATIC NATURE

on the one hand, a confederative solution would eliminate Israel's long-time demographic problem by detaching from Israeli sovereignty the vast majority of the Palestinian Arab population of the West Bank and Gaza. While the latter would be citizens of the confederation (based on their citizenship in the Palestinian federated state or entity), they could not vote in Israeli national elections. For the small minority of Palestinians residing in territory annexed by Israel, a choice could be offered: either Israeli or Palestinian citizenship. The existing Israeli Arab population would retain its full citizenship.

On the other hand, a confederation between Palestine/Jordan and Israel could create an entirely new demographic problem for the latter. The permanent linkage of Israel to a Palestinian-Jordanian federation would, in effect, mean the Jewish state's constituent membership in a confederation whose majority would likely be Arab within a relatively short time. Elazar, acknowledging this potentiality, proposes that the confederation be governed through a joint council composed of an equal number of Israeli and Palestinian/Jordanian (non-Israeli Arab) representatives. ${ }^{18}$

Would an equally-weighted Arab-Israeli framework of governance be stable over the long run? If Lebanon's 
confessional system of government provides any clues, the answer is probably not. Should the population of the confederation eventually consist of an ever-increasing Arab majority, the Palestinians and Jordanians, like the Lebanese Shi'ites in their struggle against the Maronites, might naturally demand an increasing share of power. Because the Palestinian-Jordanian federation would be looking out for its own interests first, the implications for Israel of ceding the latter a controlling share of power would be serious. Yet, were Israel to resist a change in the power structure, the entire arrangement could collapse, as it did in Lebanon. ${ }^{19}$

ECONOMIC INTEGRATION AND SHARING OF WATER RESOURCES

Common economic security, it has been seen, requires the establishment of bilateral economic ties which will reinforce interdependence, thereby creating for both sides a permanent mutual interest in the durability of peaceful relations. This is particularly true with respect to the Israelis and Palestinians, who have a quarter-decade history of economic interdependence. Whatever political settlement is ultimately agreed upon, it must take into consideration the existing network of economic linkages and infrastructure (i.e., water resources, roads, electricity grids and communications lines) connecting Israel to the territories. 
Thus, a severing of Israeli-Palestinian economic ties would not only be contrary to common security and therefore imprudent, it would be virtually impossible.

In theory, at least, no organizational mechanism is more naturally suited to the development of economic integration (i.e., a common market) and the strengthening of interdependence (i.e., a system of cross linkages) than a federal arrangement between separate political entities. A confederation between Israel and Palestine/Jordan would integrate the three diverse economies into a single, potentially prosperous economic framework. Economic cooperation, in turn, should stimulate the generation of joint-ventures and an influx of foreign investment, some of which would contribute to the resolution of region-wide problems such as water and the environment. Additionally, a confederative arrangement would offer the parties a shared responsibility in the allocation of scarce water resources which are common to the entire area and do not respect political boundaries.

The provision of mutual economic and water security, then, would be the most salient benefit of the above confederative option. Whether it is unreasonable to expect that an economic union between Israel, Jordan and an independent 
Palestinian state would similarly secure such a benefit is a question which still must be explored (Chapter 7).

\section{PALESTINIAN DISSATISFACTION AND INTERNAL STABILITY}

According to the notion of common security, an IsraeliPalestinian political settlement must be supported on each side by a majority strong enough to overcome deep societal cleavages over the question of the West Bank and Gaza. Otherwise, the resultant internal discord within one or both societies could lead to civil war, threatening to spill over into neighboring states and thereby undermining their security as well.

Elazar's proposed confederation would involve Israeli annexation of most of the Jewish territorial pockets in the West Bank and extraterritorial status for the remaining Jewish settlements, which would fall outside Israel's primary jurisdiction. ${ }^{20}$ with the extension of Israel's permanent borders and no need to dismantle any Jewish settlements, it is a virtual certainty that the vast majority of Israelis would approve of this confederative approach to a settlement.

By contrast, Elazar offers no evidence that an adequate majority of the Palestinian Arabs would consent to a federated mini-state solution. On the contrary, he seems to overlook (or underestimate) the Palestinians' potential 
reaction to a considerable expansion of Israeli national territory at their own expense and to a rejection of their universal demand for an independent state. It is quite conceivable that Arab resistance to such a settlement would reach beyond the extremist, rejectionist elements to more moderate Palestinian circles, none of which have thus far been willing to forsake their shared minimum goal of full sovereign statehood. Moreover, even in the unlikelihood that violent protest did not ensue from the outset of such a peace agreement, Palestinian opposition to its perpetuation might emerge later were Israel's confederative power to become increasingly incommensurate with its relative population size.

The issue here is not whether the Palestinians would accept a federal link with Jordan. Historically, there have been several indications that at least mainstream palestinians would ultimately agree to a Jordanian-Palestinian confederation. It should not be surprising, however, that the Palestinians insist on full independence first, prior to yielding a degree of sovereignty to a larger entity. ${ }^{21}$ That is, it appears that only sovereign statehood would reassure the Palestinians that they could enter into a federal relationship with Jordan (let alone Israel) on the basis of political symmetry rather than subservience to the Hashemites (or to the Israelis). 
Elazar fails to address adequately the question of how federated statehood would ensure Palestinian national survival over the long run. Were a substantial portion of the Palestinian population to perceive that the final settlement lacked in this regard due to their persistent fear of domination by Israel or Jordan, the envisioned peace could be a mere delusion. If, on the one hand, support for the agreement were to exist only among the more moderate, pro-Jordanian Arabs, might not Palestinian society become increasingly polarized, effectively inhibiting implementation of the settlement?

on the other hand, were a one-sided confederative solution imposed on the Palestinians (and implemented) against their will, their ensuing discontent would surely be universal. The result might be the very escalation of "terrorism" which, paradoxically, schiff and Ya'ari claim a confederative security arrangement is needed to contain. 22 In the latter case, Israel might feel compelled to react harshly in the West Bank and Gaza, perhaps by returning a substantial military presence to these areas. Such a move, in turn, would jeopardize the entire confederative scheme.

Clearly, a confederative relationship between Israel and Palestine/Jordan, though it contained some of the positive-sum elements required by common security, would nevertheless confront several serious pitfalls. Widespread 
Palestinian dissatisfaction with a self-governing arrangement that fell short of sovereign independent statehood could not be ruled out. With no way to predict authoritatively whether such opposition would be insurmountable, only one other alternative, itself problematic, remains: an independent palestinian state west of the Jordan River. This option is analyzed in Chapter 7. 


\section{CHAPTER VI NOTES}

'Daniel J. Elazar, Two Peoples... One Land: Federal Solutions for Israel, The Palestinians, and Jordan (Lanham: University Press of America, Inc., 1991) 18.

2Ibid., 8-10 and, for specific examples, 39-64. Notably, three of these federal arrangements have recently dissolved: the Soviet Union (fifteen republics); Yugoslavia (six republics); Czechoslovakia (two republics). Moreover, several of the former republics of the U.S.S.R. and Yugoslavia are presently rife with ethnic conflict.

${ }^{3}$ For a discussion on this point and detailed definitions of various federal options, see, ibid., 10-11, 18-19 and 37-64.

"Ze'ev Schiff and Ehud Ya'ari, Intifada: The Palestinian Uprising--Israel's Third Front (New York: Simon and Schuster, 1990) 333.

${ }^{5}$ For the details of the proposal, see, ibid., 327-337.

${ }^{6}$ Elazar, op. cit., 183.

${ }^{7}$ For the details of the proposed settlement, see, ibid., 183-190.

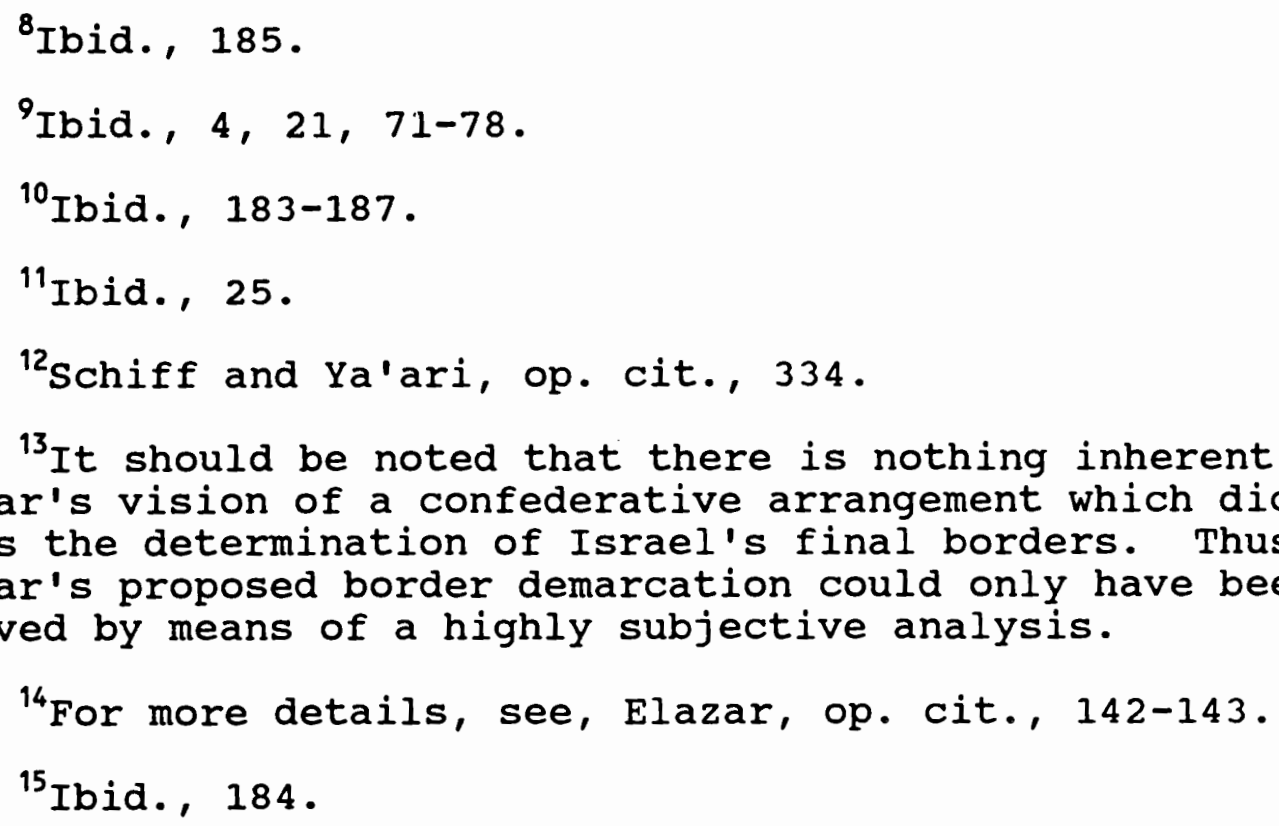


${ }^{16}$ Ibid., 183-193; Schiff and Ya'ari, op. cit., 331-336.

${ }^{17}$ Elazar, op. cit., 193.

${ }^{18}$ Ibid., 185-187. Elazar fails to note the prospect of Israeli Arab representatives on the council voting in a bloc with their Palestinian and Jordanian brethren and the potential implications thereof.

${ }^{19}$ For a detailed discussion on the failed Lebanese experiment, see, Michael C. Hudson, Arab Politics: The Search for Legitimacy (New Haven: Yale University Press, 1977) 280-294.

${ }^{20}$ Elazar, op. cit., 184.

${ }^{21}$ During the mid-1980's, the on-again-off-again PLOJordanian negotiations on the establishment of a Palestinian-Jordanian confederation ultimately broke down because of Palestinian insistence on full independence prior to confederation. Throughout his talks with PLO Chief Yasser Arafat, Jordan's King Hussein remained adamantly opposed to the latter's persistent demand for the creation of an independent Palestinian state. See, Shaul Mishal, The PLo Under Arafat: Between Gun and Olive Branch (New Haven: Yale University Press, 1986) 165-171.

${ }^{22}$ Schiff and Ya'ari, op. cit., 334. 


\section{ARAB PALESTINE}

The cornerstone is the concept of Palestinian sovereignty. Not half-sovereignty, or quasi-sovereignty or ersat $z$ sovereignty. But a sovereign, independent Palestinian state...There is no reason why the concept of Palestinian sovereignty should not accommodate provisions designed to allay legitimate fears of neighbors on a reasonable and, preferably, reciprocal basis.

--Walid Khalidi ${ }^{1}$

What are the characteristics of an independent Palestinian state west of the Jordan which could satisfy the basic requirements of common security and thereby make it a feasible alternative for a political settlement? Where would its final borders lie? Would it have to be totally demilitarized? Should it join into a confederative relationship with Jordan and/or Israel?

In order to meet the criteria set out in this study, a Palestinian state must be sufficiently independent and sovereign to satisfy the minimum Palestinian Arab demands for political self-determination. At the same time, it must be sufficiently circumscribed to ensure that it does not undermine the physical security of Israel (not to mention Jordan). Additionally, the establishment of a Palestinian state west of the Jordan must: 1) detach from Israeli 
sovereignty the vast majority of the Arab inhabitants of the West Bank and Gaza; 2) be supported by strong majorities on both sides of the Israeli-Palestinian border; and 3) permit meaningful regional economic integration, including cooperation in the allocation of scarce water resources.

THE ULTIMATE FORM OF SELF-DETERMINATION

According to Daniel Elazar, Middle East scholars and political leaders have overemphasized the 18th-century European notion of political sovereignty by equating "selfdetermination" with this prototype for sovereign statehood. ${ }^{2}$ other modes of self-determination, he argues, would--or should--satisfy Palestinian Arab demands for political independence (see Chapter 6). To be sure, an arrangement offering less than separate, sovereign statehood, such as Elazar's federated state, could conceivably provide the Palestinians with meaningful self-governance. Nevertheless, the self-rule/shared rule formula disregards entrenched Palestinian perceptions that it would not ensure Palestinian national survival over the long run.

Unquestionably, no other form of political selfdetermination would satisfy Palestinian nationalist aspirations more than the creation of a sovereign independent state. Moreover, from the Palestinian perspective, as the position of Walid Khalidi suggests (see 
quotation above), full independence need not be antithetical to Israel's security. Still, for the establishment of a Palestinian state to adhere to the principles of common security, it would have to reassure the Israelis themselves that it was not inimical to their vital interests.

\section{IMPLICATIONS FOR ISRAELI MILITARY SECURITY}

In Chapter 4, this study concluded that, from a military security standpoint, it would be imprudent for Israel to withdraw unconditionally to the pre-1967 borders. specifically, Israel would require a margin of security in the form of annexed territory or extraterritorial rights to compensate it for the asymmetrical level of risk which would be imposed on it (relative to the Arabs) by a political settlement involving territorial compromise. This asymmetry is due to: 1) the loss of strategically important territory which Israel would have to concede as part of a settlement; 2) the autocratic nature of Israel's Arab enemies; 3) the enormous gap in Arab and Israeli standing forces, which likely will not be sufficiently reduced in the foreseeable future; and 4) the persistence of deep-rooted anti-Israeli sentiment in the Arab world (see, Chapter 4, Secure Borders) .

The establishment of a sovereign, independent Palestinian state, therefore, must be predicated on the 
premise that its territory (i.e., the high ground of the West Bank) could be used by a coalition of Arab states to launch a massive military invasion of Israel. Though this Arab state threat is dormant at present, common security entails the diminution of long-term as well as immediateterm threats.

Opponents of an independent Arab Palestine west of the Jordan take this conclusion one step further by arguing that the new state itself would represent an unacceptable risk to Israel. Elazar, for example, notes the "worrisome" threat of "irreconcilables" (secular radicals and Islamic fundamentalists) in the Palestinian state. ${ }^{3}$ The latter, so labeled because they would presumably be dissatisfied with a small state limited to the West Bank and Gaza, would seek to continue their irredentist struggle against Israel by carrying out terrorist acts across the border. Warns Elazar, "All the Israeli coastal areas and the Jerusalem area--where six out of seven Israelis live--would be in the gunsights of individual terrorists. "4 These irreconcilables, moreover, would have access to a sophisticated level of weaponry, including mobile surface-to-air and surface-tosurface missiles. 5

Louis Beres concurs with Elazar's assessment. Beres warns of "PLO rejectionists" in the new state committing violent acts against Israel as a manifestation of their 
continued struggle for total "national liberation."6 Even if it were able to withstand takeover by radical insurgents, he argues, "[Arab] Palestine would inevitably become a favored launching-point for renewed terrorism against Israel. "7

That a political settlement should start from the premise that there will always be extremist Palestinian cells which harbor the desire to "liberate" all of Palestine is not in and of itself unreasonable. The arguments of Elazar and Beres, however, are suspect on at least two important points.

First, the establishment of a Palestinian state should go a long way in reducing both the means for and the practicality of continued Palestinian terrorism. The creation of an independent Arab Palestine would immediately divert most Palestinian energies and resources away from irredentism and into the enormous and engrossing tasks of state building. Moreover, the fledgling Palestinian government would possess the resources of a state apparatus and command the support of a strong majority of the populace. It would be quite capable, therefore, of either co-opting, isolating or eradicating those elements which might desire to sabotage the peace treaty with Israel. ${ }^{8}$

second, the existence of a relatively weak palestinian state would, in effect, serve as a hostage against continued 
terrorism. Upon realizing statehood, most Palestinians would suddenly have powerful vested interests (political and economic) in refraining from and/or preventing any provocations to Israel. To be sure, they would be made to understand that any serious attempt to revive their irredentist struggle against Israel, whether their leadership sponsored or merely condoned such efforts, would constitute a casus belli and result in massive Israeli retaliation. In the latter case, Israel, according to the Jaffee Center for Strategic studies, would easily be able to overrun the neighboring Palestinian state:

The balance of military power between Israel and the prospective Palestinian state would be so onesided that such a state--even if it so desired-could not alone constitute a serious threat to Israel's security and survival. Indeed, Israel is not likely to face serious military difficulties should it decide to reassert its control over the territory of the newly created state. 9

Thus, the Arab inhabitants of the West Bank and Gaza would have every incentive to exhort their government as well as each other to act responsibly vis-à-vis Israel. Otherwise, they could lose in a matter of days--perhaps even hours--all that had been achieved through years of struggle. The constraining factors of statehood notwithstanding, Elazar notes that "we have all too many examples of peoples for whom statehood has not brought moderation, but simply 
more power to do mischief."10 Yet, the only recent example he cites--the tyrannical reign of the Khmer Rouge under Pol Pot in Cambodia ${ }^{11}$--is hardly applicable to the IsraeliPalestinian conflict. Unlike the PLO or the fundamentalist Hamas movement, the Khmer Rouge was backed by a world power (i.e., China) and was not opposed by a military force even remotely as powerful as Israel's.

Moreover, while no one can predict with a high degree of certainty the future behavior of the various Palestinian groups after statehood is secured, two reasonable conclusions can be drawn. First, the intifada in general and the terrorism it spawns against Israeli citizens in particular is sure to continue and perhaps escalate if sovereign Palestinian statehood is not achieved within a reasonable timeframe. Second, whereas isolated incidents of terrorism against Israelis could persist after the establishment of an Arab Palestine, such acts, while sometimes fatal, would in no way endanger the survival of Israel.

It is therefore the conclusion of this paper that, on the one hand, an independent Palestinian state in and of itself would not constitute a significant military threat to Israel. This should remain so for the foreseeable future assuming the new state were required, as part of a political settlement, to limit its offensive military capabilities (see, Conclusion, Partial Demilitarization). 
On the other hand, Israel should be compensated, in the least zero-sum manner possible, for its cession of territorial military assets in the face of the continuing collective Arab state threat. Such a margin of security is justified by the common security principle of achieving parity by reducing strategic asymmetries (in this case, between Israel and the Arab states as a whole). It could take the form of border adjustments (territorial annexation) or extraterritorial security arrangements.

\section{SOVEREIGNTY V. SECURITY ARRANGEMENTS}

Over the past decade, some advocates of territorial compromise, especially among Israeli scholars and analysts, have been divided into two schools of thought. The traditional Israeli proponents of "territory for peace" favor new political borders which would incorporate into Israel the most strategically important parts of the West Bank and Gaza. The remaining non-annexed portions of the territories would be returned to Arab sovereignty, either Jordanian or Palestinian or both. By contrast, the second school of thought favors the establishment of security arrangements, perhaps an Israeli extraterritorial military presence, in strategic territory evacuated. The maintenance of such arrangements would presumably permit Israel to cede the entirety of the West Bank and Gaza to the Arabs. ${ }^{12}$ 
The distinguishing variable between the two schools is not a difference of opinion on the feasibility of a return to the status quo ante of June 1967 (i.e., a return by Israel to its former borders). Rather, the distinction lies in opposing political assessments on the type of Israeli sovereignty (if any) in territories now disputed which could secure Arab acceptance of a settlement while simultaneously ensuring Israeli security. ${ }^{13}$

Jerome slater, a proponent of the second school of thought, argues that Israel need not retain any sovereignty in the West Bank or Gaza. ${ }^{14}$ slater suggests that a multinational peacekeeping force indefinitely stationed in a Palestinian state west of the Jordan "could serve the same intelligence, early warning, deterrence, and to some extent even war-fighting functions as an Israeli [extraterritorial] force." 15 He notes, furthermore, that such a force would have an added advantage relative to the deployment of Israeli troops in territory evacuated or Israeli annexation of parts of the West Bank and Gaza. Specifically, the presence of an international force would be more politically palatable to the Palestinians than would these latter two alternatives, both of which would constitute a much more significant infringement on their claimed sovereignty. ${ }^{16}$

Irrefutably, the deployment of a multinational peacekeeping force would be more acceptable to the 
Palestinians than an Israeli military presence or Israeli annexation. However, slater's assertion that "in the remote case of an all-out Arab attack," the "war-fighting capabilities" of an international force would be adequate to prevent a seizure of the high ground of the West Bank ${ }^{17}$ is quite tenuous.

The extent of the military capabilities of an international force at any given point in time may be determined at the whim of political leaders whose selfinterests militate against effective collective security. That is, the deterrence of aggression against states outside their own immediate region may be deemed too costly by those governments whose military forces would be used in the effort. Although a somewhat different set of variables comes into play, the current indecisiveness of the international community regarding a course of action in wartorn Bosnia-Herzegovina may be instructive here. As this collective inability to deter Serbian aggression suggests, it is unlikely that the Israelis--or, for that matter, the Palestinians--would be willing to entrust their long-term security needs (on the eastern front) to the presence of an international force alone.

Another important factor to be considered in the sovereignty versus security arrangements debate is long-term stability. Notably, the demarcation of new, mutually 
recognized borders (assuming the parties are capable of concluding an agreement) is likely to be a more durable solution than the establishment of security arrangements involving the use of foreign forces. The former approach should lessen the expectations of either party that it could eventually modify the post-settlement status quo. By contrast, the deployment of a peacekeeping force, which by its very nature limits a state's sovereignty within its own territory, might be seen by the affected state as only a temporary infringement to be eliminated when future circumstances warranted. ${ }^{18}$

The retention by Israel of an extraterritorial military presence or the deployment of a multinational force, such as that proposed by slater, would circumscribe the sovereignty of the Palestinians in the most strategic areas of the West Bank. Yet, over time, it would be natural for the Palestinian state to seek to reassert its full sovereign control by lobbying for the removal of the foreign troops. (Indeed, a third party like the U.N. might itself conclude at some point that its forces were no longer essential to keep the peace and therefore resolve to disband them.)

It may be particularly instructive in this regard that, in late 1992, Egypt notified Israel of its desire for the removal of the Multinational Forces and observers in Sinai. This deployment, which separates the armies of Egypt and 
Israel, has increasingly become the target of nationalist sentiment. The Egyptians argue that these foreign troops are no longer necessary now that the 1979 peace treaty between the two countries has, in their view, withstood the test of time. The Israelis, taking a long-term perspective, believe that the durability of the treaty must be measured in terms of several decades, not merely several years. ${ }^{19}$

Clearly, if a Palestinian state is to be created, negotiated border adjustments would accord the final political settlement more built-in stability and security reassurances than would the stationing of foreign peacekeeping forces. What sort of modifications to the pre-1967 borders would not be inordinately zero-sum in nature and could therefore be implemented by agreement of the parties?

From a purely military perspective, the Israelis would prefer to retain most of the Jordan River Valley and to widen their country's narrow waist by absorbing the western foothills and ridges of the samarian mountains. In all likelihood, they would also seek to maintain an extraterritorial military presence along the eastern crest of the mountain ridge. All three of these areas are strategically important to Israel in terms of both topography and strategic depth (see Chapter 3, Footnotes 11 and 12). 
On the one hand, the problem with Israeli annexation of the western slopes of the Samarian mountains (including Ariel, the second largest Jewish settlement in the West Bank) is that it is a thoroughly zero-sum proposition. This territory, while it overlooks Israel's vulnerable coastal plain, lies to the immediate west of the densely populated Arab heartland of the West Bank. Israel could only annex this land to the total detriment of the Palestinians, whose compact state would be rendered too small to be economically (and psychologically) viable.

with certain relatively minor border adjustments (below), an international peacekeeping force including--and perhaps commanded by--American troops operating intelligence and early-warning installations should be sufficient for Israel's security needs on the mountain ridge. It would have to be deployed along the eastern as well as western crest, thereby eliminating the need for what would surely be an unwelcome Israeli military presence on Palestinian territory. At the same time, counterpart stations could monitor Israeli military preparations and maneuvers, thereby providing reassurances to the Palestinians.

On the other hand, Israeli retention of the majority of the Jordan Valley ${ }^{20}$ would be substantially less intrusive upon the Palestinians because this narrow strip of territory (Appendix B) is only sparsely populated with Palestinian 
Arabs. $^{21}$ As a defensive asset, it would enable the Israelis themselves to control the entrances to almost all of the major east-west axes leading up from the Jordan River to the Samarian mountains.

Admittedly, there is no guarantee that Israeli absorption of the Jordan Valley and a resultant Palestinian state virtually surrounded by Israel would prove acceptable to the Palestinians. It can only be assumed that the less territory Israel seeks to annex and the fewer the number of Arabs inhabiting that territory, the higher the probability of Palestinian acquiescence.

From a common security perspective, however, this new geographic configuration would have the advantage of effectively and unalterably meshing the physical security of the Palestinians with that of the Israelis. Future military perils to the enclosed Palestinian state (e.g., those which could be posed by rejectionist states like Iraq or Iran) would surely be recognized as threats to Israeli territory and vice-versa. The presence of Israeli brigades throughout the valley and the deployment of a U.S.-led international force along the mountain ridges would thus serve as a powerful two-pronged deterrent against major threats not only to Israel's coastal plain but to the heartland of an Arab Palestine 
as well. (Other minor border modifications are discussed in the final chapter.)

INTERNAL STABILITY: SUPPORT FOR THE SETTLEMENT

An independent Palestinian state in almost the entirety of the West Bank and Gaza, even with some limitations on its sovereignty (below), would be more likely to fulfill Palestinian nationalist aspirations than any of the other alternatives already discussed in this paper. In addition, a satisfactory solution--perhaps a special status--would have to be formulated for East Jerusalem (see, Conclusion, The Question of Jerusalem). Notably, one prominent study of what many consider to be the most hard-line segment of the Palestinian population--the Gazan refugees whose original homes were inside present-day Israel--indicates that even they would accept something approximating the above scenario. 22 Indeed, there likely would be no more generous a proposal forthcoming from Israel or any outside intermediary.

Would a sufficiently strong majority of Israelis agree to the notion of Palestinian statehood? surely, the establishment of a neighboring Palestinian state, were it simply to gloss over Israeli security concerns or require the dismantlement of all Jewish settlements in the West Bank, would prove unacceptable to the vast majority of Israelis. 
The envisaged Palestinian state above should reassure the Israelis that their physical security would not be jeopardized by its creation. Still, the presence of over 100,000 Jewish settlers residing in territory which would become Arab Palestine would clearly be a cause for concern to both sides. A political settlement intent on uprooting these communities could trigger violent opposition, particularly among militant Israeli settlers determined to remain in the territories. ${ }^{23}$ Even if such an agreement could be implemented, the vocal Jewish radical right might pose a destabilizing factor inside Israel, polarizing the public to the point of internecine strife. In the latter case, the incipient Palestinian state could be an easy target for Jewish extremist groups striving to undermine the peace treaty.

Acknowledging this danger, Mark Heller and Sari Nusseibeh suggest an arrangement combining financial incentives for voluntary "repatriation" of Jewish settlers to Israel with a system of permanent residency for those individual Israeli citizens wishing to remain in the West Bank or Gaza. ${ }^{24}$ The assumption underlying this proposal is that those settlers motivated primarily by pragmatic rather than ideological considerations--eighty percent of the settler population by one estimation ${ }^{25}$--would lose their incentive to remain in their present homes. Heller and 
Nusseibeh believe that with available, subsidized housing inside Israel, the vast majority of them would choose to relocate. ${ }^{26}$

The remaining Jewish population centers in the West Bank and Gaza, while subject to the authority and laws of an Arab Palestine, could perhaps enjoy a degree of communal autonomy similar to that of Arab municipalities in Israel. ${ }^{27}$ Though this scheme mandates Jewish submission to Arab sovereignty, it might appeal to most Israelis in that it also entails a formal Palestinian recognition of the right of Jews, as individuals, to live in the west Bank. In the final analysis, it is essential that eighty to ninety percent of the Israeli public would support this sort of arrangement. Only a majority of this size could empower the government to isolate and neutralize effectively any radical right-wing opposition to the final settlement.

ELIMINATION OF THE DEMOGRAPHIC TIME BOMB

The establishment of a Palestinian state with the suggested borders (along with Palestinian citizenship for East Jerusalem's Arabs) would virtually eliminate the Arab demographic threat to Israel's democratic and Jewish nature. It would remove from Israeli rule the bulk of the Arab inhabitants of the West Bank, East Jerusalem and Gaza Strip. Consequently, Israel's subjugation of a people against its 
will would finally end, enabling the Jewish state to remain true to its democratic ideals.

At the same time, this scenario involves Israel's absorption of only a negligible number of Arabs--perhaps a few hundred Palestinians residing in Israeli-annexed territory who would ultimately opt for Israeli citizenship (see Footnote 24). The Israelis, therefore, would not have to feel threatened by the eventuality of an Arab-dominated government rising to power and legislating the official demise of the state's Jewish and Zionist character. Most importantly, the existential dilemma which has been plaguing Israel for more than a quarter of a century would be resolved once and for all.

COMMON ECONOMIC SECURITY OR SEVERANCE OF ECONOMIC TIES?

In evaluating various alternatives for the final disposition of the territories, Daniel Elazar stresses the need for the West Bank and Gaza to maintain a close economic relationship with Israel and Jordan. ${ }^{28}$ According to Elazar, any drastic transformation in the present web of economic linkages inextricably connecting the territories to Israel would inflict grave costs on the Israelis and, especially, the Palestinians. He concludes from this premise that a "repartition" of the territories to create a separate Palestinian state is totally infeasible. ${ }^{29}$ 
To be sure, a federal arrangement (e.g., economic confederation) between the Israelis and Palestinians would be, as Elazar suggests, the most suitable option for facilitating their continued economic integration. It does not follow, however, that a political repartition of the West Bank and Gaza, one which accommodated Israel's vital security interests, would necessitate a severing of economic ties between Israel and the new state. To the contrary, it would still be very much in the best interests of a separate, independent Palestinian state to enter into a formal economic union with Israel and Jordan (see Chapter 3 ).

Patrick clawson notes that as the weakest partner, the Palestinians would stand to benefit the most from advanced economic cooperation with the Israelis and Jordanians. ${ }^{30}$ Such cooperation, he suggests, could take the form of a Middle East Benelux (after the economic union between Belgium, the Netherlands and Luxembourg). ${ }^{31}$ It is hardly unreasonable, therefore, to expect the Palestinians to agree to the establishment of a similar tripartite common market as part of a quid pro quo for Israeli acceptance of an independent Palestinian state west of the Jordan. Notably, the proven durability of Benelux, created in 1960, demonstrates that an economic confederation can fare well even though each of the constituent members is a separate sovereign state with its own agenda of national interests. 
A full-fledged Israeli-Palestinian-Jordanian common market would involve many, if not all, of the following features: 1) a joint customs tariff for imports; 2) a monetary union; 3) a free flow of labor and capital; 4) the integration of electricity grids and communication lines; and 5) common transport facilities (in particular, joint use of the Haifa, Eilat and Aqaba ports and a fully developed Gaza Port)..$^{32}$ Extensive economic cooperation of this sort, far from disrupting the existing network of economic relationships and infrastructure connecting the territories to Israel, would only build on it.

A Benelux-type economic confederation should prove profitable for each of the constituent members, particularly because the three economies involved are strong in divergent, yet complementary areas. ${ }^{33}$ At the same time, it would reinforce the economic interdependence of the parties, creating a system of cross linkages which would enhance their mutual interest in maintaining peaceful political relations.

\section{A FEDERAL ARRANGEMENT FOR WATER ALLOCATION}

At first glance, a political repartition of the territories to create a sovereign, independent state between Israel and Jordan might not seem conducive to resolving the region's acute water problems. This is, in part, because 
many of the water sources in the area, such as the West Bank aquifers, do not respect political boundaries. Commonly held vital resources (e.g., water, oil) juxtaposed with a separation of sovereign control tends to be a recipe for conflict among the states of the Middle East. Historically, these states have placed their own water needs not only before those of their neighbors and of the region as a whole, but also before other concerns, like the environment. The addition of yet another state to the mix might intensify an already bitter struggle for scarce water resources.

A final political settlement of this sort, therefore, must include a mechanism which would compel the parties (Israel, Palestine and Jordan) to share water equitably on the basis of need, access to external resources and compliance with common conservation regulations. Such a mechanism could take the form of a federal water authority to be conceived within the framework of the tripartite economic confederation. The federal water authority would be governed by a council consisting of representatives of each country. It would oversee the allocation of the immediate region's water resources and the planning and implementation of joint projects, like desalination plants and water conveyance systems. To ensure its success, the governments of Israel, Palestine and Jordan would have to 
commit to yielding some of their innate decision-making powers to the council.

The establishment of a sovereign, independent Arab Palestine, under certain conditions, would generally satisfy each of the criteria set forth in the conceptual security framework of this paper. With, inter alia, final borders that accommodated Israel's legitimate security needs and the establishment of a tripartite federal water authority as part of a larger economic confederation, this alternative would have a more reasonable chance to produce a durable peace than any of the other scenarios previously discussed. 
CHAPTER VII NOTES

'Walid Khalidi, "Thinking the Unthinkable: A Sovereign Palestinian State," Foreign Affairs 56 (1978): 701.

2Daniel J. Elazar, Two Peoples... One Land: Federal Solutions for Israel, the Palestinians, and Jordan (Lanham: University Press of America, Inc., 1991) 10-11 and 18-19.

${ }^{3}$ For Elazar's perspective on the potential threat to Israel posed by a Palestinian state, see, ibid., 71-78.

${ }^{4}$ Ibid., 76.

${ }^{5}$ Ibid.

${ }^{6}$ Louis René Beres, "Israeli Security in a Changing World," Strategic Review 18.4 (1990): 17.

7 Ibid.

${ }^{8}$ For an excellent discussion on the potential moderating influence of statehood on Palestinian maximalist goals, see, Mark A. Heller, A Palestinian State: The Implications for Israel (Cambridge: Harvard University Press, 1983) 57-68.

'Joseph Alpher et al., The West Bank and Gaza: Israel's options for Peace (Tel Aviv: Jaffee Center for Strategic Studies, Tel Aviv University, 1989) 102. Quoted in, Jerome Slater, "A Palestinian State and Israeli security," Political Science Quarterly 106 (1991): 417.

${ }^{10}$ Elazar, op. cit., 75.

${ }^{11}$ Ibid.

${ }^{12}$ Dore Gold, "Conflict Between Sovereignty and Security," Jerusalem Post week ending 28 Nov. 1992, international ed.: 6 .

${ }^{13}$ Ibid.

${ }^{14}$ Slater, op. cit., 411-429.

${ }^{15}$ Ibid. , 420. 
${ }^{16}$ Ibid. , 418-423.

${ }^{17}$ Ibid., 422. It should be noted that an effective deterrent against a foreign military takeover of the west Bank would be critical to the security of the Palestinian state as well as the security of Israel. cit., 6.

${ }^{18}$ For a discussion on this point, see, Gold, op.

${ }^{19}$ Ibid.

${ }^{20}$ Israel would annex a narrow strip of territory with a length of 32 miles and a width varying between 4.5 and 5 miles. It would span almost the entire length of the Jordan River Valley: from the Beisan Valley (below Bet She'an), extending southward through portions of the eastern samarian foothills, and then ending just north of the road from Jericho to the Allenby Bridge (see Appendix B).

${ }^{21 E l a z a r, ~ o p . ~ c i t ., ~ 82 . ~ S e e ~ a l s o, ~ R a p h a e l ~ I s r a e l i, ~}$ Palestinians Between Israel and Jordan: Squaring the Triangle (New York: Praeger Publishers, 1991) 139. According to Israeli, ninety percent of the pre-1967 West Bank Palestinian population lived outside the west Jordan valley. Of the 85,000 residing in the valley, all but 10,000 fled to Jordan during the Six-Day war never to return.

${ }^{22}$ Sara Roy, "Changing Political Attitudes Among Gaza Refugees," Journal of Palestine Studies 19.1 (1989): 78-9. This extensive survey of Gaza Arab refugees indicates that the overwhelming majority of respondents acknowledge that a political resolution of the conflict cannot be found unless they abandon the notion of reclaiming their former homes inside what is now Israel.

${ }^{23}$ Notably, a 1982 study indicates that 59 percent of Gush Emunim settlers, the highly ideological devotees of a Greater Eretz Yisrael, would oppose violent resistance against an Israeli government attempting to dismantle the settlements. See, David Weisburd and Elin Waring, "Settlement Motivations in the Gush Emunim Movement: Comparing Bonds of Altruism and Self-Interest," in David Newman, ed., The Impact of Gush Emunim: Politics and Settlement in the West Bank (New York: St. Martin's Press, 1985) 183-195. 
${ }^{24}$ Mark A. Heller and Sari Nusseibeh, No Trumpets, No Drums: A Two-state settlement of the Israeli-Palestinian Conflict (New York: Hill and Wang, 1991) 102-106. Note: similar arrangement could be worked out for Palestinians residing in territories annexed by Israel. They could choose either to relocate or remain in Israel as resident aliens. Those choosing to stay could ultimately apply for Israeli citizenship.

${ }^{25}$ Ehud Sprinzak, The Ascendance of Israel's Radical Right (New York: Oxford University Press, 1991) 312.

${ }^{26}$ Heller and Nusseibeh, op. cit., 103-104.

${ }^{27}$ Ibid. , 104-105.

${ }^{28}$ Elazar, op. cit., 85-87, 187 .

${ }^{29}$ Ibid. , 80-81 and 85-87.

${ }^{30}$ Patrick clawson, "The Limited scope for Economic Cooperation in the Contemporary Levant," in Steven $\mathrm{L}$. Spiegel, ed., The Arab-Israel Search for Peace (Boulder: Lynne Rienner Publishers, 1992) 92-93. Practically speaking, the Palestinians would have little choice but to enter into an economic confederation. Left to fend for itself, their fledgling state, with its small size and paucity of natural resources, would have to endure one economic hardship after another.

$$
\begin{aligned}
& { }^{31} \text { Ibid., } 93 . \\
& { }^{32} \text { Ibid. } \\
& { }^{33} \text { Ibid. }
\end{aligned}
$$


CHAPTER VIII

CONCLUSION

The September 1993 Israeli-PLO interim arrangement on autonomy for the Palestinian inhabitants of the Gaza strip and Jericho is clearly a watershed event in contemporary Middle East history. It is a necessary first step toward a mutual acknowledgement by the parties of one another's legitimate long-term security interests. Such an acknowledgement, in turn, reflects the fundamental principle underlying the notion of common security: one side of a conflict cannot feel secure if the other side feels threatened. Not until this principle is irreversibly instituted by the parties as the ariving force governing Israeli-Palestinian relations will a final political settlement be possible.

In the meantime, Israeli-PLO negotiations face significant obstacles, not the least of which is the vehement opposition already crystallizing on both sides. The risk of diplomatic impasse is considerable. This will be particularly the case if and when the final status talks begin to center on the establishment of an independent Palestinian state, the alternative rated most favorably according to the conceptual framework presented in this 
study. In addition to permanent borders and the existing Jewish settlements, other complex and contentious issues must be worked out to the satisfaction of both sides. Among the potential roadblocks are the status of Jerusalem, the extent of demilitarization of the Palestinian state, and the timeframe for implementation.

\section{THE QUESTION OF JERUSALEM}

Most observers believe that the case of Jerusalem will prove to be the most difficult of all the problems addressed in the negotiations. Even the moderates on both sides who are otherwise disposed toward compromise might cling to entirely inflexible positions when it comes to Jerusalem, a city whose symbolic importance to both Jews and Moslems should not be underestimated. Whereas the Israelis are almost unanimous in their insistence that Jerusalem remain a united city and the eternal capital of Israel, the Palestinians are equally adamant in their demand that East Jerusalem be the capital of their future state.

still, the notion of common security can once again be invoked to enable the parties to overcome seemingly irreconcilable positions. A creative, positive-sum solution predicated on common security would purposely obscure the issue of sovereignty in such a way that both the Israelis and Palestinians could claim that their primary interests had 
been secured. For example, a mutually acceptable solution could take the form of an Israeli-Palestinian federated county encompassing an expanded East Jerusalem (out to Ma'ale Adumim), the southern portion of the city from the 1949 armistice line to the current municipal boundary, and the protruding "finger" of northern Jerusalem (see Appendix B). West Jerusalem, which is not disputed, would remain under absolute Israeli sovereignty. ${ }^{1}$

The territory within the newly established county would be divided into Jewish and Arab municipalities along the lines of the standard U.S. county. For example, areas such as Neve Ya'akov, East Talpiot, Gilo, and Ma'ale Adumim would constitute possible Jewish municipalities; neighborhoods like Anata, El-Ezariyya and Abu Dis would each be part of larger Arab districts. Generally, Jewish residents of the county would vote in Israeli national elections as well as countywide and individual municipal elections; Arab residents would participate in the latter two types of elections in addition to Palestinian national elections. The county would be governed by an overarching joint council, which could be co-chaired by an Israeli and a Palestinian. While the national seat of government of Arab Palestine would be located in East Jerusalem, Israel would 
still maintain control of the federation's security against external threats. ${ }^{2}$

\section{PARTIAL DEMILITARIZATION}

Israeli proponents of territorial compromise typically speak of the need to demilitarize any portions of the West Bank and Gaza evacuated by Israel as part of a political settlement. To be sure, limitations should be imposed on the military forces of the proposed Palestinian state. The most important of these constraints would be a ban on the acquisition of those weapons which would enable the Palestinian military to partake in offensive operations (i.e., surface-to-surface missiles, tanks, artillery and combat aircraft). In addition, the Palestinian state would be prohibited by treaty from permitting foreign forces or military advisers, such as those of other Arab states, to be stationed in its territory.

Notably, precedents exist whereby sovereign states (e.g., Japan) have found it in their best interests to comply with long-term military restrictions imposed on them within the context of a peace settlement. Similarly, the Palestinians would have to determine on a perpetual basis that upholding such a treaty obligation was in their national interests. A treaty provision that would unequivocally equate any breach of the demilitarization of 
Palestinian territory to an act of war--and a casus belli for Israel--could serve this purpose. That is, it would provide the Palestinians with an obvious long-term incentive to comply with the limitations imposed on their military forces. Nevertheless, a Palestinian state, as Mark Heller notes, would require some military capability, not only for internal security but for symbolic reasons as well. 3 Moreover, because of the above constraints, it would arguably be beneficial to the Palestinians to enter into a formal security alliance with Israel and Jordan.

\section{TIMEFRAME FOR IMPLEMENTATION}

Undoubtedly, the Palestinians desire statehood sooner rather than later. However, due to the asymmetrical nature of the concessions that would be required of the Israelis relative to the Palestinians (tangible territorial assets versus a formal renunciation of irredentist claims), the former would surely insist on a phased implementation. Politically, implementation in stages, whereby Israel would incrementally relinquish both territory and sovereign control, is a requirement for the success of this option. Specifically, it would create modalities of cooperation and co-existence which could serve as confidence-building measures for both peoples, particularly the securityobsessed Israelis. Implementation of each successive stage 
would be contingent upon satisfactory compliance by both sides with the interim agreements made in all prior phases.

A phased implementation would also allow for a more orderly transfer of power and would provide the Palestinians the time necessary to develop fully their self-governing institutions. Nevertheless, it is equally important that the transition period not be so long that it provide ammunition to Palestinian opponents of the settlement who would claim that the phased implementation was really a smokescreen for continued Israeli control of the West Bank and Gaza. The timeframe, therefore, should be psychologically satisfactory in terms of imparting hope on the Palestinian population of the territories that their political independence was truly within reach. A reasonable timeframe would be no less than five years but should probably not exceed eight.

\section{A FINAL WORD}

To ensure that a Palestinian state would not pose a threat to Israeli security or regional stability, its creation presupposes the implementation of at least three additional safeguards. In keeping with the spirit of common security, these safeguards would be highly beneficial to the well-being of the Palestinians as well. 
First, Middle East peace cannot occur in a vacuum. An Israeli-Palestinian political settlement must take place within the context of an overall resolution of the ArabIsraeli conflict. With an independent Palestinian state existing alongside their borders, the Israelis would feel reassured about their security only if, at a minimum, syria, Lebanon, Jordan, and Saudi Arabia also had established fully normalized relations with the Jewish state.

Second, the economic viability of the incipient Palestinian state would be predicated on the generosity of the wealthier Arab gulf states, Japan, the European Economic Community and the United States. Without a substantial infusion of funds into the West Bank and Gaza for economic development (e.g., infrastructure, modern industrial plant, port facilities and desalination), an economically weak Arab Palestine would be politically unstable and could upset the newly created regional equilibrium. ${ }^{4}$

The third safeguard is related to the second. A sudden and massive influx of refugees into Arab Palestine would clearly overwhelm the new state's absorptive capacity. ${ }^{5}$ An economy suffering from soaring unemployment, high taxes, and a constant strain on housing and other infrastructure could become an ideal breeding ground for economically frustrated Palestinians seeking subversive, even irredentist, solutions. To preclude such a danger to both Israel and the new state, the Palestinians would have to agree as part of 
the final settlement to a staggered system of refugee absorption over several years.

An Israeli-Palestinian political settlement which satisfied the vital security interests of both sides would have an enormous ripple effect throughout the Middle East. on an ideological level, it would remove one of the underlying sources of the deep-rooted collective Arab animosity toward the Jewish state. On a pragmatic level, it would enable Israel and its Arab neighbors to combine resources and work together to resolve the daunting social and economic problems of the region which have never been adequately addressed. By cooperating to fight common threats rather than fighting each other, the Arabs and the Israelis would find themselves cultivating a new modus vivendi which could serve as the underpinning of a durable and comprehensive peace. 
CHAPTER VIII NOTES

${ }^{1}$ The approach to West Jerusalem through the Jerusalem Corridor should also be widened, permitting Israel to retain control over the main Tel Aviv-Jerusalem highway. Specifically, Israeli annexation of a small territorial belt which included the Latrun Salient (Appendix B) would correct a conspicuous geographic anomaly created by the 1949 armistice lines. In return, the new Palestinian state should be allowed to incorporate fully those Arab villages which literally straddle the armistice boundary and thus constitute demographic anomalies (e.g., Barta'a and Baqa el Gharbiya).

${ }^{2}$ For a discussion on possible solutions regarding Jerusalem, see, Daniel J. Elazar, Two Peoples... one Land: Federal Solutions for Israel, the Palestinians, and Jordan (Lanham: University Press of America, Inc., 1991) 147-170; Mark A. Heller and Sari Nusseibeh, No Trumpets, No Drums: A Two-state settlement of the Israeli-Palestinian Conflict (New York: Hill and Wang, 1991) 114-124. For a detailed examination of federated county systems, see, John C. Bollens and Henry J. Schmandt, The Metropolis: Its People, Politics and Economic Life (New York: Harper and Row, 1970) 324-339.

${ }^{3}$ Heller and Nusseibeh, op. cit., 66.

${ }^{4} \mathrm{~A}$ major step in this direction has already been taken. At an international conference in Washington on october 1 , 1993, 43 countries pledged $\$ 2$ billion over five years in assistance to the Palestinians as they prepare to assume administrative responsibility for the Gaza strip and Jericho. Among the countries pledging were the U.S., the 12-member European Community, Japan, Saudi Arabia and Israel.

${ }^{5} \mathrm{Heller}$ and Nusseibeh estimate that 750,000 to one million Palestinian refugees--newcomers and returnees--would eventually immigrate to a new Palestinian state. See, Heller and Nusseibeh, op. cit., 90-91. 
REFERENCES CITED

Ajami, Fouad. The Arab Predicament: Arab Political Thought and Practice Since 1967. New York: Cambridge University Press, 1981.

Alpher, Joseph, et al. The West Bank and Gaza: Israel's options for Peace. Tel Aviv: Jaffee Center for Strategic Studies, Tel Aviv University, 1989.

Ariel, Yaakov. "The Land and the State." Nekuda 15 May 1981: 3 .

Beres, Louis René. "Israeli Security in a Changing World." Strategic Review 18.4 (1990): 11-22.

Bollens, John C., and Henry J. Schmandt. The Metropolis: Its People, Politics and Economic Life. New York: Harper and Row, 1970.

Brown, Harold. Thinking About National Security: Defense and Foreign Policy in a Dangerous World. Boulder: Westview Press, 1983.

Clawson, Patrick. "The Limited Scope for Economic Cooperation in the Contemporary Levant." The ArabIsraeli Search for Peace. Ed. Steven L. Spiegel. Boulder: Lynne Rienner Publishers, 1992. 81-101.

Collins, Liat. "Water as the Way to Peace." Jerusalem Post week ending 9 Jan. 1993, international ed.: 8B.

Day, Arthur R. East Bank/West Bank: Jordan and the Prospects for Peace. New York: Council on Foreign Relations, Inc., 1986.

Diab, M.z. "A Proposed Security Regime for an Arab-Israeli Settlement." The Arab-Israeli Search for Peace. Ed. Steven L. Spiegel. Boulder: Lynne Rienner Publishers, 1992. 159-172.

Dillman, Jeffrey D. "Water Rights in the Occupied Territories." Journal of Palestine Studies 19.1 (1989): 46-71. 
Elazar, Daniel J. Two Peoples... one Land: Federal Solutions for Israel, the Palestinians, and Jordan. Lanham: University Press of America, Inc., 1991.

Fishelson, Gideon. "Regional Economic Cooperation in the Middle East." The Arab-Israeli Search for Peace. Ed. Steven L. Spiegel. Boulder: Lynne Rienner Publishers, 1992. 103-120.

Flapan, Simha. The Birth of Israel: Myths and Realities. New York: Pantheon Books, 1987.

Garfinkle, Adam. Israel and Jordan in the Shadow of War. New York: St. Martin's Press, 1992.

Gasteyger, Curt. "New Dimensions of International security." Washington Quarterly 8.1 (1985): 85-91.

Gold, Dore. "Conflict Between Sovereignty and Security." Jerusalem Post week ending 28 Nov. 1992, international ed.: 6 .

---. "Great Expectations." Jerusalem Post week ending 8 Feb. 1992, international ed.: 9, 12 .

Hannum, Hurst. Autonomy, Sovereignty and SelfDetermination: The Accommodation of Conflicting Rights. Philadelphia: University of Pennsylvania Press, 1990.

Harkavy, Robert E. "After the Gulf War: The Future of Israeli Nuclear strategy." Washington Quarterly 14.3 (1991): 161-179.

Hassan bin Talal. Palestinian Self-Determination: A study of the West Bank and Gaza Strip. New York: Quartet Books, Inc., 1981 .

Heller Mark A. A Palestinian State: The Implications for Israel. Cambridge: Harvard University Press, 1981.

Heller Mark A., and Sari Nusseibeh. No Trumpets, No Drums: A Two-state settlement of the Israeli-Palestinian Conflict. New York: Hill and Wang, 1991.

Hudson, Michael c. Arab Politics: The Search for Legitimacy. New Haven: Yale University Press, 1977.

Hunter, F. Robert. The Palestinian Uprising: A War by other Means. Berkeley: University of California Press, 1991. 
Independent Commission on Disarmament and security Issues. Common Security: A Blueprint for Survival. New York: Simon and Schuster, 1982 .

International Institute for strategic studies. The Military Balance, 1992-1993. London: Brassey's, 1992.

Israeli, Raphael. Palestinians Between Israel and Jordan: Squaring the Triangle. New York: Praeger Publishers, 1991.

Kahane, Meir. They Must Go. New York: Grosset and Dunlap, 1981.

---. Thorns in Your Eyes. New York: Drucker Publishing Co., 1980 .

Kaufman, Daniel J., Jeffrey S. McKitrick, and Thomas J. Leney. U.S. National Security: A Framework for

Analysis. Lexington: Lexington Books, 1985.

Khalidi, walid. "Thinking the Unthinkable: A Sovereign Palestinian State." Foreign Affairs 56 (1978) : 696713.

Klare, Michael T., and Daniel C. Thomas, eds. World Security: Trends and Challenges at Century's End. New York: St. Martin's Press, 1991.

Krause, Lawrence B., and Joseph S. Nye. "Reflections on the Economics and Politics of International Economic Organizations." World Politics and International Economics. Ed. C. Fred Bergsten and Lawrence B. Krause. Washington, D.C.: The Brookings Institution, 1975. 323-342.

Livneh, Eliezer. Israel and the crisis of Western Civilization. Tel Aviv: Schoken Publishing House, 1972 .

Lustick, Ian S. For the Land and the Lord: Jewish Fundamentalism in Israel. New York: Council on Foreign Relations, Inc., 1988.

Mishal, Shaul. The PLO Under Arafat: Between Gun and Olive Branch. New Haven: Yale University Press, 1986.

Perlmutter, Amos. Israel: The Partitioned State. New York: Charles Scribner's Sons, 1985. 
Peters, Joan. From Time Immemorial. New York: Harper and Row, Publishers, 1984 .

Pipes, Daniel, and Adam Garfinkle. "Is Jordan Palestine?" Commentary 86.4 (1988): 35-42.

Quandt, william B. Camp David: Peacemaking and Politics. Washington, D.C.: The Brookings Institution, 1986.

---. Decade of Decisions: American Foreign Policy Toward the Arab-Israeli Conflict 1967-1976. Berkeley: University of California Press, 1977.

Ramati, Yohanan. "Israel and Nuclear Deterrence." Global Affairs 3 (1988): 175-185.

Risse-Kappen, Thomas. "From Mutual Containment to Common Security: Europe During and After the Cold War." World Security: Trends and Challenges at Century's End. Ed. Michael T. Klare and Daniel C. Thomas. New York: st. Martin's Press, 1991. 123-143.

Rosecrance, Richard, and Arthur Stein. "Interdependence: Myth or Reality?" World Politics 26 (1973): 1-27.

Rosen, Howard. "Economic Consequences of the Intifada in Israel and the Administered Territories." The Intifada: Its Impact on Israel, the Arab World and the Superpowers. Ed. Robert O. Freedman. Miami: Florida International University Press, 1991. 374-385.

Rowley, Gwyn. "The West Bank: Native Water-Resource Systems and Competition." Political Geography Quarterly 9 (1990): 39-52.

Roy, Sara. "Changing Political Attitudes Among Gaza Refugees." Journal of Palestine Studies 19.1 (1989): $72-82$.

Safran, Nadav. Israel: The Embattled Ally. 2nd ed. Cambridge: Belknap/Harvard University Press, 1981.

Sahliyeh, Emile. In Search of Leadership: West Bank Politics since 1967. Washington, D.C.: The Brookings Institution, 1988 .

Said, Edward W. Blaming the Victims: spurious Scholarship and the Palestinian Question. New York: Verso, 1988. 
Saunders, Harold $\mathrm{H}$. The other Walls: The Politics of the Arab-Israeli Peace process. Washington, D.C.: American Enterprise Institute for Public Policy Research, 1985.

Schechtman, Joseph B. Postwar Population Transfers in Europe: 1945-1955. Philadelphia: University of Pennsylvania Press, 1962.

Schiff, Ze'ev, and Ehud Ya'ari. Intifada: The Palestinian Uprising--Israel's Third Front. New York: Simon and Schuster, 1990.

Shalev, Aryeh. "Security Dangers from the East." Jerusalem Quarterly 30 (1984): 132-144.

-- The Intifada: Causes and Effects. Jerusalem: Jerusalem Post Press, 1991.

Sharon, Ariel. "Autonomy Means Statehood." Jerusalem Post week ending 22 Aug. 1992, international ed.: 7 .

--. Warrior. New York: Simon and Schuster, 1989.

Slater, Jerome. "A Palestinian state and Israeli security." Political science Quarterly 106 (1991): 411-429.

Smith, Charles D. Palestine and the Arab-Israeli Conflict. New York: st. Martin's Press, 1988.

Sprinzak, Ehud. The Ascendance of Israel's Radical Right. New York: Oxford University Press, 1991.

"A Startling Poll." Jerusalem Post week ending 22 May 1993, international ed.: 8 .

Steinberg, Matti. "The PLO and the Mini-settlement." Jerusalem Quarterly 21 (1981): 129-144.

Weisburd, David, and Elin Waring. "Settlement Motivations in the Gush Emunim Movement: Comparing Bonds of Altruism and Self-Interest." The Impact of Gush Emunim: Politics and settlement in the West Bank. Ed. David Newman. New York: St Martin's Press, 1985. 183-199.

Wright, Quincy. A study of War. 2nd ed. Chicago: University of Chicago Press, 1965. 
APPENDIX A

MIDDLE EAST BALANCE OF POWER

\begin{tabular}{|c|c|c|c|c|c|c|}
\hline & Israel & Egypt & Syria & $\operatorname{Iraq}^{a}$ & Jordan & Iran \\
\hline $\begin{array}{l}\text { Population } \\
\text { (millions) }\end{array}$ & 4.55 & 54.11 & 11.72 & 17.85 & 3.10 & 54.37 \\
\hline $\begin{array}{l}\text { Active } \\
\text { Military } \\
\text { Manpower } \\
\text { (thousands) }\end{array}$ & 141 & 448 & 404 & 1000 & 82.25 & 604.5 \\
\hline $\begin{array}{l}\text { Reserve } \\
\text { Military } \\
\text { Manpower } \\
\text { (thousands) }\end{array}$ & 504 & 604 & 400 & 850 & 35 & 350 \\
\hline $\begin{array}{l}\text { Combat } \\
\text { Aircraft }\end{array}$ & 753 & 589 & 609 & 513 & 135 & 121 \\
\hline Tanks & 3794 & 2440 & 4050 & 5630 & 1150 & 530 \\
\hline Artillery & 1100 & 2380 & 2500 & 4500 & 690 & 800 \\
\hline
\end{tabular}

Source: Michael Widlanski, ed., Can Israel Survive a Palestinian State? (Jerusalem: Institute for Advanced Strategic and Political Studies, 1990).

The Iraqi figures predate the 1991 Gulf war. The International Institute for Strategic studies (IISS) estimates that Iraq lost up to 247 combat aircraft, 3,000 tanks and 2,140 artillery pieces during the war. Presently, Iraq is believed to have 382,500 men in its active forces (not including 25,000 paramilitary troops) and 650,000 reservists. See, IISS, The Military Balance, 1992-1993 (London: Brassey's, 1992) 110-111. 


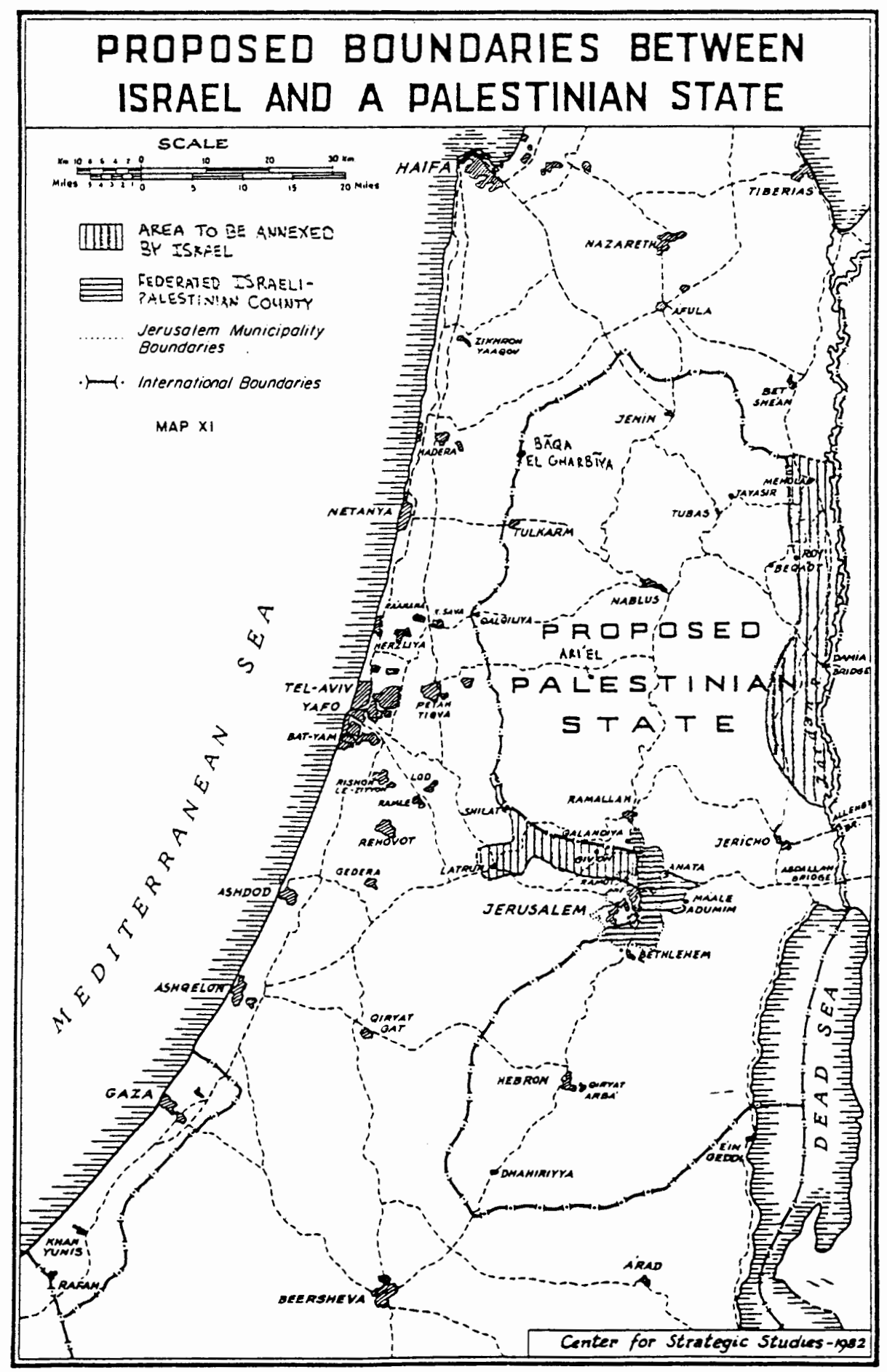

